\title{
Democratic Republic of Timor-Leste: Selected Issues and Statistical Appendix
}

This Selected Issues paper and Statistical Appendix for the Democratic Republic of Timor-Leste was prepared by a staff team of the International Monetary Fund as background documentation for the periodic consultation with the member country. It is based on the information available at the time it was completed on January 9, 2007. The views expressed in this document are those of the staff team and do not necessarily reflect the views of the government of the Democratic Republic of Timor-Leste or the Executive Board of the IMF.

The policy of publication of staff reports and other documents by the IMF allows for the deletion of market-sensitive information.

To assist the IMF in evaluating the publication policy, reader comments are invited and may be sent by e-mail to publicationpolicy@imf.org.

Copies of this report are available to the public from

International Monetary Fund $\bullet$ Publication Services

700 19th Street, N.W. • Washington, D.C. 20431

Telephone: (202) 6237430 • Telefax: (202) 6237201

E-mail: publications@imf.org•Internet: http://www.imf.org

Price: $\$ 18.00$ a copy

\section{International Monetary Fund Washington, D.C.}





\section{INTERNATIONAL MONETARY FUND \\ DEMOCRATIC REPUBLIC OF TIMOR-LESTE \\ Selected Issues and Statistical Appendix}

Prepared by Theo Thomas, Hiroko Oura, Tobias Rasmussen (all APD), Kevin Yitae Kim, and Tehmina Khan (both FAD)

Approved by the Asia and Pacific Department

January 9, 2007

Contents

Page

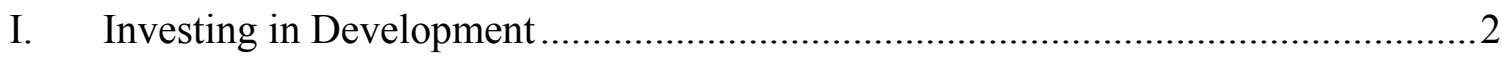

II. Domestic Taxes in Oil Producing Countries: Are They Needed? The Case of

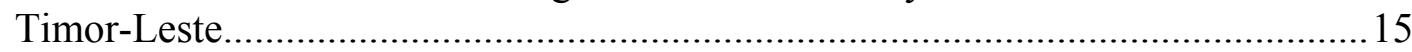

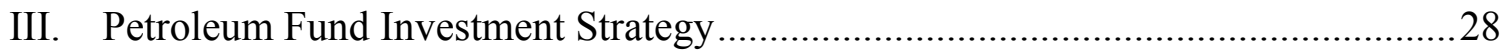

Statistical Appendix Tables

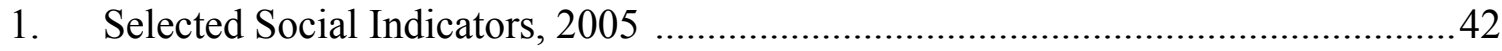

2. Selected Economic Indicators, 2001-06 ………............................................... 43

3. Non-oil Gross Domestic Product by Sectoral Origin, 2000-06 …………...............44

4. Non-oil Gross Domestic Product by Expenditure, 2000-06 …………………........45

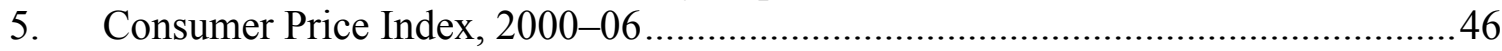

6. Monetary Survey, 2001-06.............................................................................

7. Balance Sheet of the Banking and Payments Authority, 2000-06 ..........................48

8. Consolidated Balance Sheet of Financial Institutions, 2000-06 ……....................49

9. Central Government Budget Operations, Cash Basis, 2002/03-2006/07 .................50

10. Central Government Domestic Non-oil Revenues, 2001/02-2006/07 .....................51

11. Oil/Gas Revenues, 2000/01-2006/07 …………..........................................52

12. General Government Expenditure Composition, 2001/02-2004/05 ……..............53

13. Public Sector Employment and Wages, 2002/03-2005/06 ....................................54

14. Autonomous Agencies Operations, 2002/03-2006/07 …………………………....55

15. Operations of the Power Authority, 2001/02-2006/07 ........................................56

16. Combined Sources Fiscal Operations 2001/02-2005/06 ......................................57

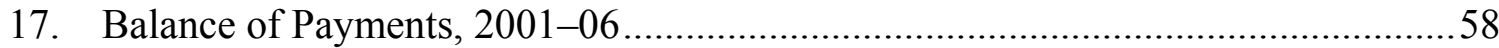

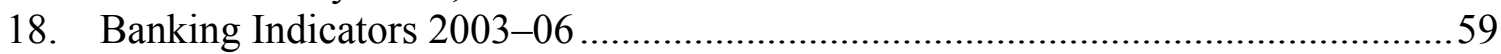

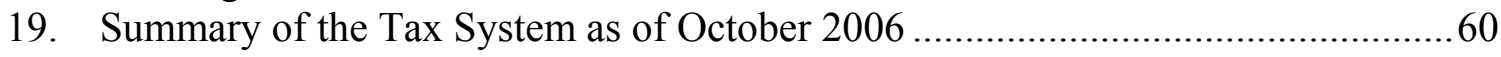




\section{INVESTING IN DEVELOPMENT ${ }^{1}$}

\section{A. Introduction}

1. Stronger economic growth is central to the government's campaign to reduce poverty in Timor-Leste. There is an urgent need to raise living standards. Social indicators point to low life expectancy, high illiteracy, and limited access to basic services. Timor-Leste scores lower on the United Nation's Human Development Index than any of the ASEAN member countries. While petroleum revenue has surged in the last few years, non-oil GDP per capita remains below $\$ 400$ a year and poverty has increased.

\begin{tabular}{|lrrrrrr|}
\hline \multicolumn{7}{|c|}{ Table I.1. Human Development Indicators } \\
\hline & $\begin{array}{c}\text { Timor- } \\
\text { Leste } \\
(2004)\end{array}$ & $\begin{array}{c}\text { Esia } \\
\text { Pacific } \\
(2003)\end{array}$ & $\begin{array}{c}\text { South } \\
\text { Asia } \\
(2003)\end{array}$ & $\begin{array}{c}\text { Leveloped } \\
\text { Countries } \\
(2003)\end{array}$ & $\begin{array}{c}\text { Developing } \\
\text { Countries } \\
(2003)\end{array}$ & $\begin{array}{r}\text { Hncome } \\
\text { OECD } \\
(2003)\end{array}$ \\
& 55.5 & 70.5 & 63.4 & 52.2 & 66.0 & 78.9 \\
Life expectancy at birth (years) & 50.1 & 90.4 & 58.9 & 54.2 & 76.6 & $\ldots$ \\
Adult literacy rate (age 15 and over, percent) & 732 & 5,100 & 2,897 & 1,328 & 4,359 & 30,181 \\
GDP per capita (PPP US\$) & 0.426 & 0.768 & 0.628 & 0.518 & 0.694 & 0.911 \\
Human development index 1/ & & & & & \\
\hline Source: United Nations Development Programme (2006). & \\
1/ The UN's human development index is a composite measure of income, health, and educational attainment. \\
\hline
\end{tabular}

\section{The government's development strategy envisions a major step-up in public} spending that, in combination with rising levels of private investment, would lift economic growth to 7-8 percent a year. ${ }^{2}$ This is supported by estimates suggesting that a real growth rate of non-oil GDP of at least 7 percent per year is needed to significantly reduce the incidence of poverty. The focus on GDP is backed by international experience, which shows that economic growth is key to poverty reduction (Dollar and Kraay, 2002).

3. Is the objective of 7-8 percent growth feasible? This chapter presents evidence on linkages between investment and growth observed in other countries in order to gauge the expected impact of increasing public investment in Timor-Leste. The results indicate that the level of capital expenditure envisioned in the government's strategy could significantly boost economic growth and reduce poverty. Capital formation has been central to progress in Asia's most successful economies. Still, raising public investment is only part of the solution. Investing wisely will be critical. Further, economic development will depend on restoring security after the recent civil unrest and on improving the general business environment.

\footnotetext{
${ }^{1}$ Prepared by Tobias Rasmussen.

2 The government's economic strategy for the medium term was outlined in the report Combating Poverty as a National Cause (GTL, 2006), presented at the Timor-Leste Development Partners Meeting in April 2006. The strategy is underpinned by 17 Sector Investment Programs and aims at achieving goals first articulated in the 2002 National Development Plan.
} 
High economic growth in other countries has primarily been associated with private investment and relying on public investment is unlikely to be successful in the long run. Finally, raising public investment in itself will be a challenge, given current problems in budget execution.

4. In the effort to improve living standards, perhaps the biggest challenge will be to increase employment opportunities for the large number of unemployed and underemployed. The 2004 census shows that 75 percent of the labor force is employed in subsistence agriculture or fishing and only about 12 percent is in the formal sector receiving wages. With the population growing rapidly at over 3 percent a year, the monetized economy will need to expand at a rapid pace just to keep up with new entrants to the labor force and prevent living standards from deteriorating. Even in the most optimistic scenario, it will take many years before poverty and dependence on subsistence farming are significantly reduced.

\begin{tabular}{|lcr|}
\hline \multicolumn{3}{|c|}{ Table I.2. Timor-Leste: Labor and Poverty Indicators } \\
\hline & 2001 & 2004 \\
\hline Population (thousands) & 846 & 925 \\
Labor force (thousands) & 257 & 289 \\
Employment (in percent of labor force) & n.a. & 98.2 \\
Government & n.a. & 5.8 \\
UN and NGOs & n.a. & 3.2 \\
Private industry & n.a. & 3.2 \\
Self-employed & n.a. & 10.7 \\
Subsistence farming & n.a. & 75.3 \\
Poverty incidence (percent below threshold) & & \\
National poverty line & 39.5 & 41.5 \\
\$1 a day & 20.0 & 21.5 \\
\hline Source: GTL (2006); Timor-Leste Census 2004. & \\
\hline
\end{tabular}

\section{B. Background}

\section{The low level of development in Timor-Leste is not a new phenomenon.}

Combining data collected from the Indonesian period up to 1999 with the more recent data for Timor-Leste, the UNDP estimates that the Human Development Index (HDI) has shown significant improvement over the past decade, albeit from a very low level. The massive destruction and dislocation surrounding the referendum period in 1999 caused a dip in the HDI and the impact of these events are still being felt. It has been estimated that 70 percent of the total capital stock was destroyed in the turmoil. In addition, the majority of managerial positions were held by Indonesians who left the country. The result was a pronounced shortage of both physical and human capital. Ensuring continued development in Timor-Leste

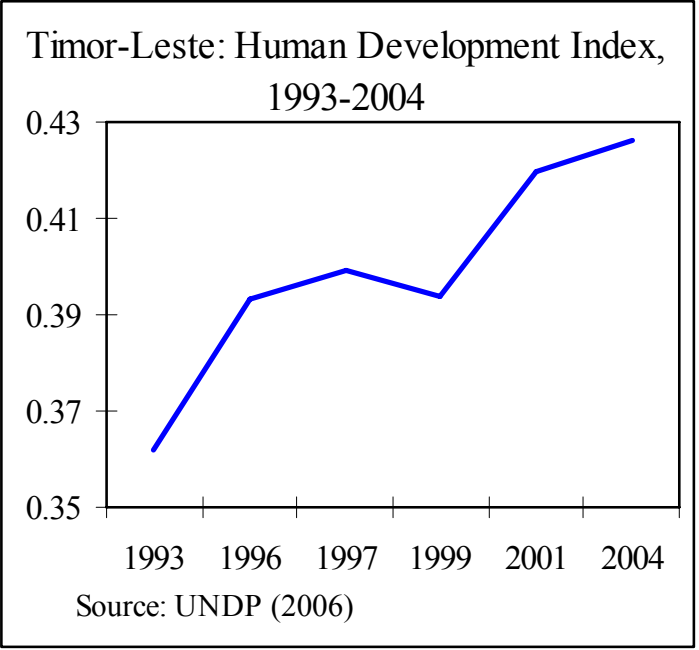
will require alleviating these constraints.

6. Recent economic developments - shaped by conflict, donor assistance, and public spending-have resulted in slow progress towards developmental objectives. 
Following the 1999 referendum, total (combined sources) public expenditure grew rapidly to 70 percent of non-oil GDP where it remained for several years. Together with the rise and subsequent decline in UN peacekeeping spending, this produced an initial spike in economic activity followed by a significant contraction. A modest recovery took hold in 2005, driven by an expansion in the small private sector, but was cut off by civil unrest starting in early 2006. Non-oil GDP is still below the level of 2001 and the private sector remains heavily dependent on servicing the needs of the public sector and the expatriate community. Private exports and investments remain very low, both below 3 percent of non-oil GDP. One consequence of the relatively poor growth performance in recent years has been the estimated increased in the rate of poverty between 2001 and 2004.

Table I.3. Timor-Leste: Selected Economic and Social Indicators (in millions of US dollars, unless otherwise noted)

\begin{tabular}{lrrrrrr}
\hline & 2000 & 2001 & 2002 & 2003 & 2004 & 2005 \\
\hline Non-oil GDP at current prices & 316 & 368 & 343 & 336 & 339 & 350 \\
Non-oil real GDP (percent change) & 13.7 & 16.5 & -6.7 & -6.2 & 0.3 & 2.3 \\
& \multicolumn{7}{c}{ (Fiscal years ending June 30$)$} \\
Public expenditures & 116 & 195 & 231 & 241 & 237 & 232 \\
Recurrent & 90 & 139 & 154 & 182 & 187 & 180 \\
$\quad$ Government & 24 & 41 & 43 & 60 & 63 & 68 \\
$\quad$ Donor programs & 66 & 98 & 111 & 122 & 124 & 112 \\
Capital & 25 & 56 & 77 & 60 & 50 & 53 \\
$\quad$ Government & 12 & 6 & 8 & 11 & 9 & 10 \\
$\quad$ Donor programs & 13 & 50 & 70 & 48 & 41 & 42 \\
Government revenues & 2 & 29 & 36 & 54 & 76 & 311 \\
Oil/gas revenue & $\ldots$ & 13 & 11 & 29 & 41 & 266 \\
Other (excluding grants) & 2 & 15 & 25 & 24 & 35 & 45 \\
Donor assistance & 297 & 501 & 412 & 344 & 301 & 211 \\
Budget support grants & 36 & 32 & 23 & 33 & 35 & 34 \\
Development \& technical & 80 & 148 & 180 & 170 & 165 & 154 \\
Other, incl. UN operations & 182 & 321 & 210 & 141 & 102 & 23 \\
Memorandum items & \multicolumn{7}{c}{ (in percent of non-oil GDP) } & 71 & 70 & 68 \\
Public expenditures & 39 & 57 & 65 & 71 & 15 & 15 \\
Capital & 9 & 16 & 22 & 18 & 15
\end{tabular}

\section{Timor-Leste's basic infrastructure remains in urgent need of improvement.}

Public investment has been on a downward trend since 2002 and much of the spending in the post-independence period has been directed at rehabilitation rather than new construction. As a result, a large share of the population remains without access to basic services. The public electricity utility only recently commenced 24-hour supply of electricity in the capital, and electricity is available at most a few hours a day in the provincial cities. With only 5 percent of rural households electrified, it is estimated that less than a quarter of households have access to electricity at all. There is an extensive $6,000 \mathrm{~km}$ road network, but much of this has fallen into serious disrepair, leaving large parts of the country inaccessible during the wet season. Water and sanitation services - key to improving public health - are inadequate, and two-thirds of the population is without access to safe water. 
Table I. 4. Infrastructure Indicators

\begin{tabular}{lrcc}
\hline & $\begin{array}{c}\text { Electricity } \\
\text { Generation } \\
\text { (kwh per } \\
\text { capita) }\end{array}$ & $\begin{array}{c}\text { Roads } \\
\text { (km per } \\
1,000 \\
\text { people) }\end{array}$ & $\begin{array}{c}\text { Access to } \\
\text { Improved Water } \\
\text { (in percent of } \\
\text { population) }\end{array}$ \\
\hline World (1998-2002) & 2,483 & 3.4 & 81 \\
Low income & 397 & 1.2 & 76 \\
Low and middle income & 1,140 & 2.1 & 79 \\
Middle income & 1,801 & 2.9 & 82 \\
High income & 17,516 & 14.5 & 100 \\
Timor-Leste (2005) 1/ & 67 & 10.1 & 37 \\
\hline
\end{tabular}

Sources: National authorities; and IMF (http://www.imf.org) for rest of world.

1/ Electricity generation for Dili only.

8. The government's economic plan views growth as the most important factor for poverty reduction. A multi-pronged strategy involves: (i) maintenance of macroeconomic stability; (ii) pursuit of structural reforms to improve the business climate; (iii) improvement of infrastructure; (iv) introduction of skill-building programs; (v) better access to basic services; (vi) and targeted poverty intervention. An overarching feature of the strategy is a big push in investment in basic infrastructure, schools, hospitals, and other essential facilities. The aim is to increase public investment to above 30 percent of non-oil GDP during the rest of the decade, but keep current expenditure broadly unchanged. Along with efforts to improve the climate for private investments, the objective is to reach total investment levels of 40 percent of non-oil GDP by 2010. In later years, it is envisioned that increasing private sector investment would allow the public sector to curtail spending while maintaining total investment at a level sufficient to sustain high growth.

\section{The authorities are in a good position to ramp up public spending in their}

pursuit of economic growth. Sustainable income from the petroleum wealth is currently estimated at some $\$ 280$ million a year and is expected to grow as new fields are developed. Moreover, while expected to decline gradually, disbursements from development partners are likely to remain above $\$ 100$ million a year over the medium term. ${ }^{3}$ As a result, even without relying on domestic taxation, the government would have room to increase capital spending.

\footnotetext{
3 The government's projection of receipts from donors assumes that, following its recent qualification, TimorLeste will gain rapid access to development assistance from the United States under the Millennium Challenge Account (MCA).
} 


\section{The public sector investment program calls for total investment during}

FY 2006/07-FY 2009/10 of around \$600 million, more than doubling relative to the previous four-year period. While the composition is still being worked out and full and ontime implementation is unlikely, this could include about $\$ 200$ million for electrification, nearly $\$ 180$ million for road and bridge rehabilitation and construction, about $\$ 100$ million for water supply and sanitation, and $\$ 40$ million to construct new schools. The centerpiece of the investment plan is a proposal currently being prepared for the MCA, which involves total spending of $\$ 450$ million over a five-year period starting mid 2007, of which MCA would fund about $\$ 360$ million. For 2015, the targeted objectives include providing electricity to 55 percent of households, safe water and sanitation to 80 percent of the population, and reducing the proportion of the population below the poverty line by half. This would allow substantial progress towards the Millennium

Public Sector Investment Program, FY2004/05 - FY2009/10

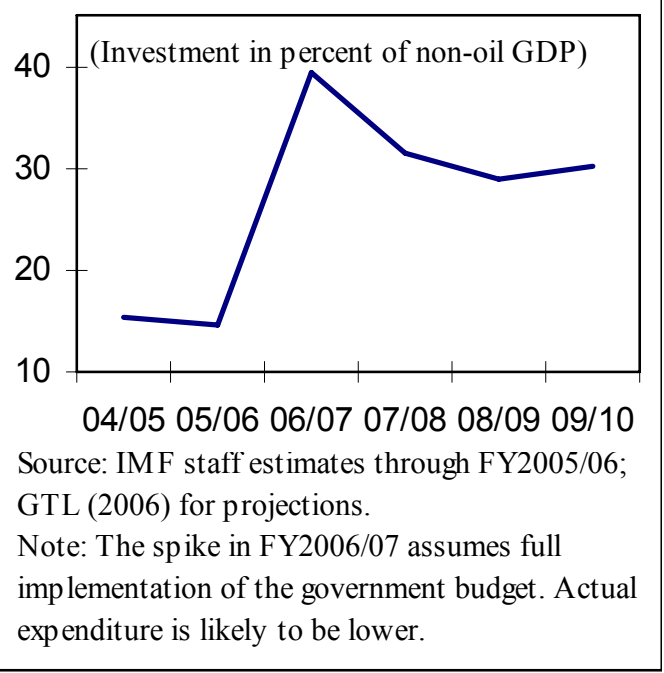
Development Goals.

\section{The government estimates that implementation of its strategy will allow} economic growth to reach at least 7 percent a year by the end of the decade. Realistically, the number of jobs can be expected to grow at a slightly slower pace than the overall economy. In the near term, with total non-subsistence employment currently estimated at less than 140,000, the economy would thus be adding at most 10,000 jobs a year. At the same time, the population is set to increase by about 30,000 each year and the working age population by about half that. This means that the number of people in unemployment or depending on subsistence farming is likely to be increasing for some time, even if the growth objective is met. The economy would be adding an increasing number of new jobs, but it would take several years to see a significant reduction in the number of poor.

\section{Lessons From Other Countries}

\section{The successful growth experience of other Asian economies is an important}

model for Timor-Leste. During the past four decades, Asia has grown faster than any other region in the world, making big strides in catching up with the income levels in industrial countries. The best performing of these neighboring countries are a source of inspiration for the economic strategy that is being pursued. One key lesson from the region is the value of high investment. 
13. The importance of capital formation for economic growth is clear. The high growth rates in East Asia have generally been associated with very high investment levelsSingapore tops the chart with an average investment ratio of over 30 percent during 1960-1994. Indeed, Young (1995) finds that the remarkable rise in living standards in Hong Kong SAR, Singapore, South Korea and Taiwan Province of China, during the postwar period was primarily the result of the accumulation of physical and human capital and increased labor supply, as opposed to pure

\begin{tabular}{|c|c|c|c|}
\hline & $\begin{array}{c}\text { Investment } \\
\text { (share of GDP) }\end{array}$ & $\frac{\text { Annual grc }}{\text { Capital stock }}$ & $\begin{array}{l}\text { wth rate } \\
\text { Real GDP }\end{array}$ \\
\hline China & 22.3 & 6.7 & 6.8 \\
\hline East Asia & 21.1 & 9.9 & 6.8 \\
\hline Indonesia & 18.1 & 8.3 & 5.7 \\
\hline Korea & 23.5 & 12.6 & 8.5 \\
\hline Malaysia & 25.6 & 10.0 & 7.0 \\
\hline Philippines & 19.8 & 6.0 & 3.8 \\
\hline Singapore & 33.2 & 13.1 & 8.3 \\
\hline Taiwan Province of China & 20.0 & 12.2 & 7.7 \\
\hline Thailand & 25.6 & 10.6 & 8.7 \\
\hline South Asia & 18.9 & 5.2 & 4.2 \\
\hline Sub-Sahara & 19.0 & 4.8 & 2.9 \\
\hline Middle East & 19.0 & 7.1 & 4.5 \\
\hline Latin America & 21.4 & 5.4 & 4.2 \\
\hline Industrial countries & 20.8 & 4.5 & 3.5 \\
\hline
\end{tabular}
productivity growth. This was brought about by high physical investment, rising educational attainment, and greater labor force participation. At a more general level, Mankiw, Romer, and Weil (1992) show that a model focusing on accumulation of human as well as physical capital provides a good explanation of variations in income levels in a sample of 98 countries over the period 1960-85.

\section{Looking more specifically at public investment, there is a large literature} pointing to the positive effects of basic infrastructure. Romp and de Haan (2005) provide an overview of the literature and find that there is increasing consensus among researchers that public capital furthers economic growth, although the magnitude of the impact is not necessarily very big and depends importantly on the type of investment that is undertaken. Such results are hardly surprising given the key role of infrastructure, as well as the scope for inefficient pork-barrel projects. One key conclusion that emerges from the literature is that the productivity of public capital is highest in countries with a small stock of public capital (Demetriades and Mamuneas, 2000), in line with classical marginal productivity theory. This suggests that additional government investments in Timor-Leste's capital-strapped economy can have a high pay-off, provided governance problems can be avoided and spending allocated to the most deserving projects.

15. The benefits of public investments may well go beyond higher output. Servén and Calderón (2004) provide one of the most comprehensive studies of the impact of infrastructure development, using a large panel data set encompassing over 100 countries and spanning the years 1960-2000. They find that infrastructure investment not only raises growth but also lowers income inequality. Conceptually, infrastructure may reduce poverty by helping the poor gain access to core economic activities and boosting their human capital via the impact on health and education levels. Quantitatively, the study finds that a one 
standard deviation increase in both the quantity and quality of the aggregate stock of infrastructure would raise the annual rate of economic growth by 3.6 percentage points and reduce the Gini coefficient by $0.07 .{ }^{4}$ To put these figures in perspective, the results imply that bringing infrastructure from the level of say, Peru (in the bottom quartile among Latin American countries), to the level of say, South Korea (the median country in East Asia), would increase the rate of economic growth by 5 percentage points and lower the Gini coefficient by 0.1 . While this very large impact offers support to Timor-Leste's investment strategy, it should be recognized that it presupposes a huge jump in the capital stock that would take years, or even decades, to obtain.

\section{In order to achieve the desired effect, the investment projects that are} undertaken will have to be subject to careful prioritization and implemented efficiently. In this respect, a number of recent studies, including Fan et al. (2004), and Fan and Rao (2003), show that investment in improving agricultural productivity, roads, and education have been particularly helpful in boosting output in developing countries. Looking specifically at Asia, Cook et al. (2005) find that transport and energy investment have benefited the poor as well as the non-poor. Moreover, several studies have found that investment in water and sanitation play a key role in reducing inequality (Servén and Calderón, 2004, and the references therein).

\section{While increasing public investment may help stimulate growth and reduce} poverty, it is important to acknowledge that improving the basic infrastructure is not the only determinant of success. Replicating the experience of the high-performing Asian Tigers will require progress on many fronts. Critically, the strong growth performance of East Asia was linked primarily to private investment, with public investment representing only about a third of the total. A good infrastructure is important, but increased economic activity requires that the private sector leverage this asset with investment in productive capacity. This, in turn, requires a business environment conducive to entrepreneurship and private sector activity. Overall, government spending will need to be carefully prioritized and the investment climate backed up by supportive institutions and a stable macroeconomic environment. $^{5}$

\section{How Much to Invest}

18. A key question for Timor-Leste is how much to invest. Investing too little to achieve the growth objective has tangible detrimental consequences for poverty. At the same

\footnotetext{
${ }^{4}$ A one standard deviation increase in the infrastructure index constructed by Servén and Calderón (2004) amounts to an improvement similar to that achieved by China, Indonesia, Korea, and Malaysia in the three decades up to 1996-2000.

${ }^{5}$ See IMF (2005a, Chapter I) for a discussion of the impediments to growth in Timor-Leste, including specific legislative initiatives that could stimulate private sector activity.
} 
time, there are also problems associated with over-shooting. Large fiscal expansions risk running into bottlenecks and creating upward price pressure. Moreover, given limited implementation capacity, there is a danger of poor-quality outcomes if spending is rushed. While the composition of investment will be at least as important, the aim here is to establish at a very general level some pointers as to how much capital spending is needed in the short to medium term. Given the still very small size of the private sector, the focus is on the overall level of public investment during the next few years and the expected outcome of the government's plan for a marked step-up in capital spending. In principle, the question of how much to invest should consider both human and physical capital. However, given that TimorLeste's efforts to increase human capital are mostly borne out in construction of schools and health-related infrastructure, and thus reflected in the physical capital stock, the analysis does not seek to separately quantify the former.

\section{A rough estimate of what to expect from different levels of capital spending can} be obtained by considering the relationship between investment and output in other countries. Based on the data in Table 5, in East Asia the gross incremental capital-output ratio (ICOR) averaged about 31/3 during 1960-94. ${ }^{6}$ More recently, the gross ICOR in Asia has been increasing, indicating a decline in the productivity of investment, and is currently around 4.7. This increase is consistent with a declining productivity of capital following years of heavy investment. In Timor-Leste the small capital stock would point to highly productive investments and hence a relatively low ICOR.

\section{Drawing lessons from other countries is complicated by Timor-Leste's} dependence on public investment. It is empirically difficult to distinguish the relative productivity of public versus private investment and it is not obvious that the experience of countries where investment was primarily undertaken by private parties is fully transferable to Timor-Leste. Given the potential for inefficient investment, it is fair to consider that overreliance on public investment may have a negative impact on the capital productivity, potentially offsetting the positive effect on productivity of increasing investment from a low initial capital stock. On balance, it may be reasonable to assume that these two effects cancel out and that the overall productivity of capital in Timor-Leste would be roughly similar to the current regional average. On this basis, a gross ICOR of $4 \frac{1}{2}$ would imply that total investment would need to reach 32 percent of non-oil GDP in order to achieve real growth of 7 percent a year. Such inference, however, should only be considered indicative, as it presupposes that investment can be efficiently absorbed by the economy. With large increases in investment, this may be difficult to achieve in the short run and higher growth may materialize slowly.

\footnotetext{
${ }^{6}$ The ICOR is defined as the change in the dollar value of the capital stock divided by the change in output. Given difficulties in measuring net changes in the capital stock, the numerator is typically approximated by gross investment. To distinguish the two calculations, this chapter refers to net and gross ICORs.
} 


\section{Rather than just looking at the ratio of total investment to GDP, it is useful to} consider actual changes in the capital stock. With natural depreciation, a larger capital stock means that gross investments will need to increase just to maintain existing assets. An interesting exercise is therefore to consider the relationship between growth and net change in the capital stock, correcting for differences in depreciation. The results in Table 6 show that this net ICOR value averaged 2.4 in four countries in East Asia during the 1970s and 1980s. According to this data, net ICORs tended to increase over time, again consistent with the productivity of capital being higher at

\begin{tabular}{|lrrrrr|}
\hline \multicolumn{6}{|c}{ Table I.6. Net Incremental Capital-Output Ratios } \\
\hline Period & Korea & Singapore & Thailand & Malaysia & Average \\
\hline $1971-74$ & 1.5 & 2.5 & 2.1 & 1.6 & 1.9 \\
$1975-79$ & 2.0 & 2.8 & 1.9 & 2.0 & 2.2 \\
$1980-84$ & 3.2 & 3.3 & 2.1 & 2.6 & 2.8 \\
$1985-88$ & 2.0 & 4.3 & 1.9 & 3.0 & 2.8 \\
Average & 2.2 & 3.2 & 2.0 & 2.3 & 2.4 \\
\hline Source: Larrain and Vergara (1993) \\
\hline
\end{tabular}
earlier stages of development.

\section{Estimating the size of the capital stock is associated with considerable} uncertainty but reveals some important insights. Changes in the estimated capital stock alone do not explain well changes in output in Timor-Leste during FY2000/01-FY2005/06, with the ICOR being highly unstable and even negative in some years. This is not odd given that economic activity has been heavily influenced by security developments and international peacekeeping operations. Nevertheless, if the security situation is stabilized, future growth will rely on the ability to improve the physical and human capital stock in order to support homegrown economic activity. Considering the low starting point and the past level of public investment, the total capital stock is currently estimated at about 115 percent of non-oil GDP. ${ }^{7}$ This is very low compared to other countries where the ratio of capital to GDP is typically estimated at $2 \frac{1}{2}-3 .^{8}$ That suggests that the productivity of new capital would be high, although the impact may be offset by dependence on the public sector.

\footnotetext{
${ }^{7}$ For present purposes, Timor-Leste's capital stock was estimated using the perpetual inventory method, based on total public (combined sources) investment since FY2000/01, a depreciation rate of 10 percent, and the assumption that the capital stock was in a steady state prior to the loss of 70 percent due to the turmoil in 1999. Private sector investments are not considered, as these have been of an unknown but small magnitude and it is unclear if they have even been sufficient to offset the natural depreciation.

${ }^{8}$ See e.g., IMF (2005b) for estimates of the capital-output ratios in other Asian economies.
} 


\begin{tabular}{|lrrrrrr|}
\hline \multicolumn{7}{|c|}{ Table I.7. Timor-Leste: Growth, Investment and Capital Stock } \\
\hline & $2000 / 01$ & $01 / 02$ & $02 / 03$ & $03 / 04$ & $04 / 05$ & $05 / 06$ \\
\hline Non-oil real GDP (percent change) & 15.2 & 4.0 & -6.4 & -3.0 & 1.3 & 0.3 \\
Public investment (in percent of non-oil GDP) & 16.3 & 21.7 & 17.6 & 14.8 & 15.3 & 14.9 \\
Capital stock (in percent of non-oil GDP) 1/ & 75.8 & 87.3 & 101.6 & 109.1 & 112.2 & 115.6 \\
Net ICOR & 0.7 & 3.7 & -1.2 & -1.4 & 3.5 & 11.9 \\
\hline Source: National authorities and Fund staff estimates. \\
1/ From 2000/01, additions to the capital stock are based on public investment \\
alone. Private investment has been of an uncertain magnitude but likely no \\
more than 2-3 percent of non-oil GDP during the last couple of years. \\
\hline
\end{tabular}

23. Considering the low capital stock, the experience of other countries suggests that the planned levels of capital expenditure could give a significant boost to growth in Timor-Leste. With a difficult starting point and an over-reliance on public investment, it could be reasonable to assume that the net ICOR value in Timor-Leste would be at the higher end of those found in Table I.6, perhaps around 3. Such a value would mean that a 7 percent growth rate of non-oil GDP purely from public sector capital accumulation would require an investment ratio of 30 percent, increasing to about 35 percent by the end of the decade. ${ }^{9}$ While this would be a big step up from recent levels, it is less than the investment ratio in the budget for FY2006/07 of almost 40 percent.

However, given limited implementation capacity and an expected reduction in external assistance over the next few

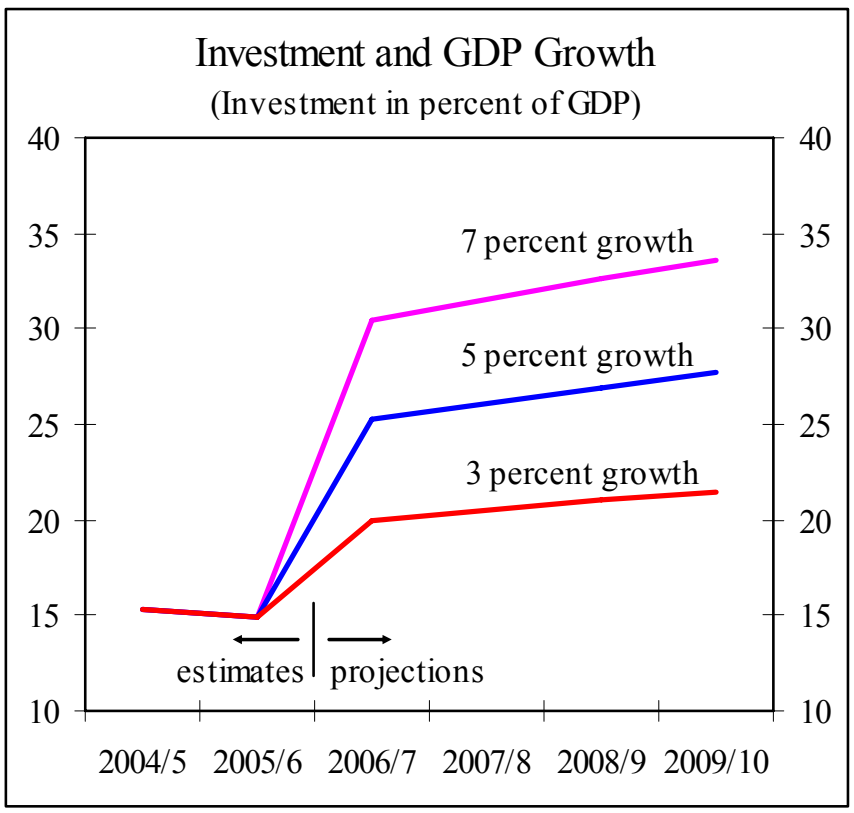
years, reaching such investment levels will require a considerable effort. Indeed, persistent difficulty in executing budgeted expenditure plans is one of the major obstacles to growth in Timor-Leste and it is unlikely that the capital budget for the current fiscal year will be fully implemented.

24. Failing to reach investment objectives will have significant consequences. With a net ICOR value of 3 , the calculations suggest that if the ratio of public investment to non-oil GDP were only increased to about 20 percent of GDP, the contribution to growth would remain low at around 3 percent per year and not sufficient to reduce poverty. While such

\footnotetext{
${ }^{9}$ These figures imply a gross ICOR of $4 \frac{1}{2}$, increasing to over 6 over the following two decades.
} 
calculations are merely indicative and reflect linkages that would take some time to materialize, the results illustrate the importance of improved budget execution. Actual growth levels will depend on a range of factors, including security developments and private investment decisions. Moreover, it is assumed that higher expenditure will translate into a proportional increase in needed public infrastructure, where in practice there is a risk of wasteful or poorly prioritized spending. At the same time, the assumed net ICOR value may be too pessimistic, with a value of 2.5 implying that the 7 percent growth target would require investment levels of only around 27-28 percent of non-oil GDP.

\section{E. Conclusions}

25. To promote human development and reduce poverty, the growth rate of TimorLeste's economy will need to accelerate markedly. The government's strategy recognizes economic growth as the single most important factor for poverty reduction and targets a growth rate in real non-oil GDP of 7-8 percent a year. The strategy rests on a substantial increase in public investment, made possible by surging oil revenue and high levels of donor assistance. This focus on economic growth and increased investment is appropriate and supported by international experience. Still, it will be essential to improve the general business environment, as long-term growth and job creation will need to come from the private sector. The distribution of income also matters, with no guarantee that overall growth will benefit the poor, even if experience from other countries suggests that investments in infrastructure can help reduce inequality.

\section{Shortcomings in essential infrastructure are a powerful argument for increased}

investment. The events of 1999 led to a large loss of physical and human capital, and access to basic public services is very low by international standards. This suggests a high return to new investment. Based on linkages between investment and growth seen elsewhere in Asia, it is estimated that raising the ratio of public investment to non-oil GDP to above 30 percent, as currently planned, could yield the desired rate of economic growth. With good progress on the Sector Investment Programs, such a level of investment is within reach, albeit requiring significant improvement in implementation capacity.

27. Simply raising spending will not be enough. The focus of this analysis was on public investment in physical capital but that does not mean that the composition is unimportant. To reach the desired effect, all projects will need to be subject to careful prioritization and scrutiny, taking into account limits on how quickly the economy can absorb new capital. A key issue will be to plan for recurrent costs and ensure proper maintenance of new assets. Increasing the human capital stock will also be important. Further, public investment alone will not be able to sustain high economic growth over the longer term. At present, the private sector is small and unlikely to provide the necessary stimulus, but, over time, private investment will need to play a prominent role. One way of encouraging this development would be to seek a large degree of private sector participation in planned investment projects. 


\section{References}

Collins, Susan M. and Barry P. Bosworth, 1996, "Economic Growth in East Asia," Brookings Papers on Economic Activity, Vol. 1996 (2), pp. 135-91.

Cook, Cynthia C. et al., 2005, Assessing the Impact of Transport and Energy Infrastructure on Poverty Reduction (Manila: Asian Development Bank).

Demetriades, Panicos O. and Theofanis P. Mamuneas, 2000, "Intertemporal Output and Employment Effects of Public Infrastructure Capital: Evidence from 12 OECD Economies," The Economic Journal, Vol. 110, pp. 687-712.

Dollar, David and Aart Kraay, 2002, "Growth is Good for the Poor," Journal of Economic Growth, Vol. 7, pp. 195-225.

Fan, Shenggen, Xiaobo Zhang, and Neetha Rao, 2004, "Public Expenditure, Growth, and Poverty Reduction in Rural Uganda," DSDG Discussion Paper No. 4 (Washington, D.C.: International Food Policy Research Institute).

Fan, Shenggen and Neetha Rao, 2003, "Public Spending in Developing Countries: Trends, Determination, and Impact," EPTD Discussion Paper No. 99 (Washington, D.C.: International Food Policy Research Institute).

Government of Timor-Leste, 2006, Combating Poverty as a National Cause: Promoting Balanced Development and Poverty Reduction (Dili, Timor-Leste: Government of Timor-Leste).

International Monetary Fund, 2005a, "Democratic Republic of Timor-Leste-Selected Issues and Statistical Appendix," IMF Country Report No. 05/250 (Washington, D.C.).

— , 2005b, World Economic Outlook, September 2005: Building Institutions World Economic and Financial Surveys (Washington, D.C.).

Mankiw, N. Gregory, David Romer, and David Weil, 1992, "A Contribution to the Empirics of Economic Growth," The Quarterly Journal of Economics, No. 107 (2), pp. 407438.

Larrain, F. and Vergara, R., 1993, "Investment and Macroeconomic Adjustment: The Case of East Asia," ed. by Serven, L. and Solimano, A. in Striving for Growth after Adjustment: The Role of Capital Formation (Washington, D.C.: World Bank). 
Romp, Ward, and Jakob de Haan, 2005, "Public Capital and Economic Growth: A Critical Survey," The European Investment Bank Papers, Vol. 10 (1), pp. 40-71.

Servén, Luis and Cesar Calderón, 2004, "The Effects of Infrastructure Development on Growth and Income Distribution," Policy Research Working Paper Series No. 3400 (Washington, D.C.: World Bank).

Young, Alwyn, 1995, "The Tyranny of Numbers: Confronting the Statistical Realities of the East Asian Growth Experience," The Quarterly Journal of Economics, Vol. 110 (3), pp. 641-80.

United Nations Development Programme, 2006, Timor-Leste-Human development Report 2006: The Path out of Poverty (Dili, Timor-Leste: United Nations Development Programme). 


\section{Domestic Taxes in Oil Producing Countries: Are They Needed? The Case of TIMOR-LESTE ${ }^{10}$}

\section{A. Introduction}

28. Timor-Leste is in the enviable situation of witnessing a significant expansion of its energy related fiscal revenue since oil and gas production started in earnest in 2004 . Oil and gas revenue projected for the next 20 years from the fields already in operation is estimated at more than $\$ 9$ billion in NPV terms, more than sufficient to finance even a fairly ambitious medium-term expenditure program (Figure II.1). New fields, such as Greater Sunrise, may become operational in the coming years.

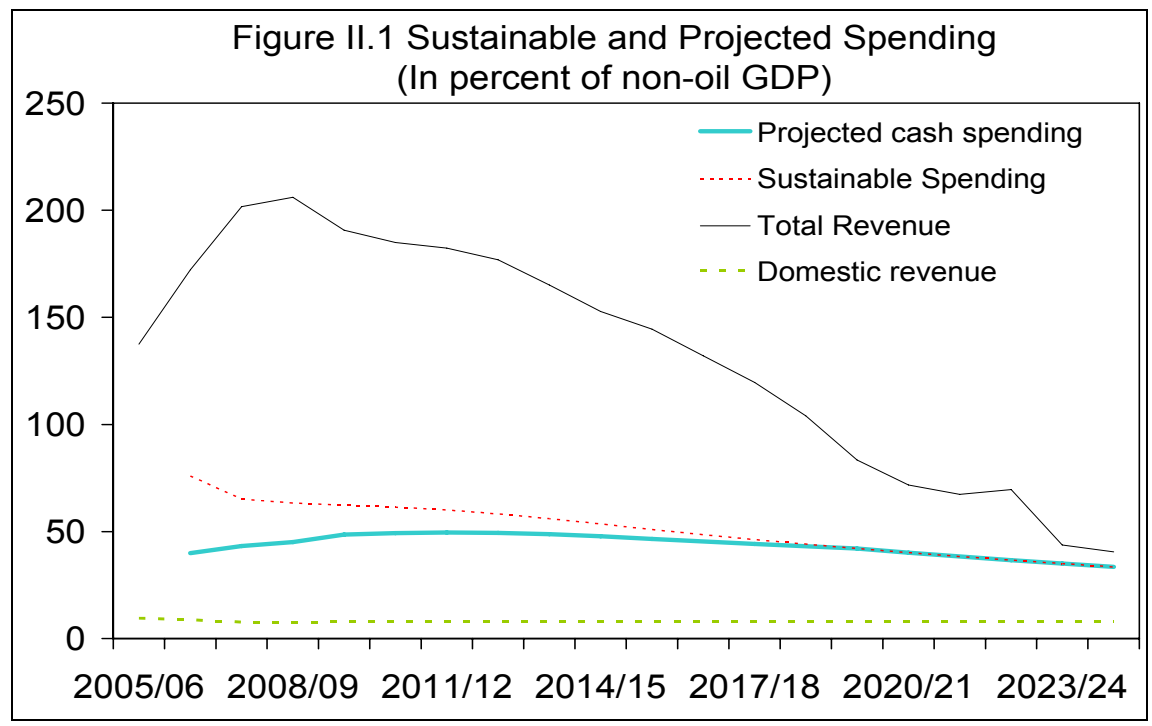

29. The favorable energy revenue outlook creates an opportunity to reform the nonoil (or "domestic") tax regime without compromising fiscal sustainability. ${ }^{11}$ This raises such fundamental questions as: "Does Timor-Leste need non-oil tax revenue with such substantial oil revenue?" and "If a domestic tax base is indeed needed, what is its appropriate structure?" The government has shown considerable interest in these issues as a means to "spur growth and create jobs" and has requested advice from the international community.

30. This paper reviews the major issues related to tax policy reform in Timor-Leste. The main findings are that: (a) from a narrow revenue-raising perspective domestic taxes will constitute a small share of sustainable income for the foreseeable future and, with expenditure expected to be below this level, there is scope for reducing further the tax take; (b) however, it would be prudent to maintain a non-oil tax structure, even if collection and

\footnotetext{
${ }^{10}$ Prepared by Kevin Yitae Kim, Tehmina Khan (both FAD), and Theo Thomas (APD).

${ }^{11}$ For a description of sustainable spending used in Timor-Leste, see Box 1 in Timor-Leste-2006 Article IV Consultation Staff Report.
} 
tax rates are very low, so as to avoid complete reliance on a single, highly volatile revenue source; (c) domestic taxes could enhance government accountability and help to achieve equity goals; (d) although the existing tax system is already relatively uncomplicated, there is scope for further simplification which, alongside reductions in tax rates, could provide a much needed stimulus for future private sector development; and (e) a key consideration for tax policy and reform is the extremely limited administrative capacity in both the public and private sectors.

31. The chapter is organized as follows: Section B provides a brief overview of the current tax system in Timor-Leste, with comparisons to similar economies; Section C reviews issues to consider when discussing non-oil tax systems in an oil economy; Section D considers lessons from country experience with tax policy reform; and Section E concludes the chapter with considerations on future tax policy reform for Timor-Leste.

\section{B. The Current Tax System in Timor-Leste}

\section{The current domestic tax system is appropriately straightforward, given the} administrative constraints and newly built institutions. ${ }^{12}$ Simplicity is a necessary feature of the tax system to ensure that it is aligned with the very limited capabilities of tax administration and private business, where accountancy and similar skills are in limited supply. Consumption taxes are relatively simple with uniform rates - a uniform import duty of 6 percent, a set of excises (most of them at the rate of 12 percent), and a sales tax imposed only on import goods at the uniform rate of 6 percent. The income tax has features that make it fairly easy to administer, such as a scheduler structure (different types of income are taxed separately from each other) and extensive use of final withholding.

\section{Timor-Leste shares many features associated with a low domestic tax base in} other countries. These include: (i) low GDP per capita and a large informal sector that cannot be taxed directly; (ii) dominance of the agriculture sector, which is hard to tax; and (iii) capacity constraints that hinder the ability of the government to collect taxes (Keen and Simone, 2004). Non-oil tax revenue amounted to 8.6 percent of non-oil GDP in 2005/06 in Timor-Leste, in comparison to low-income neighboring countries averages of 13 percent of GDP, while non-oil tax revenues in Sub-Saharan oil producing countries are around 20 percent and 9 percent of non-oil GDP and GDP, respectively. ${ }^{13}$ However, many poor postconflict countries, such as Uganda, Mozambique, Rwanda and Cambodia have struggled for many years after their conflicts to lift tax revenue above 10 percent of GDP.

\footnotetext{
12 See the Tax Summary for a detailed description of the current tax system, which was modified from the basic Indonesian system inherited in 1999.

${ }^{13}$ Low-income neighboring countries includes Lao P.D.R., Cambodia, Vietnam, and Papua New Guinea, and Sub-Saharan African countries includes Angola, Cameroon, Chad, Republic of Congo, Guinea, Gabon, and Nigeria.
} 
34. Timor-Leste also shares a similar tax structure with many low income countries in that it relies predominantly on taxes collected at the border. Countries with low administrative capacity and small formal economies tend to rely more heavily on trade taxes and other taxes. In Timor-Leste the sales and most excises are collected at the border along with trade taxes, which combined amount to about two-thirds of non-oil taxes (Appendix II.1). This system is administratively simple and, in the absence of domestic production for excisable or other taxable consumption goods, there is little economic difference between a consumption tax and a tariff. All consumption taxes, except service taxes on hotels and restaurants, are collected at the border. In time, as administrative capacity develops, consideration may be given to a more efficient value-added dominated tax system. $^{14}$

\section{There are few similarities between Timor-Leste and other oil-producing} economies, perhaps in part reflecting the wide spectrum of tax systems in those countries. Tax systems range from those relying almost completely on energy taxation, with very rudimentary or no non-oil tax systems (e.g., Brunei), to systems with some taxes on corporate profits but no tax on wages and consumption (e.g., Saudi Arabia), to countries where comprehensive taxes on corporate and personal incomes and on private consumption (VAT and excises) coexist with elaborate energy taxes (e.g.,

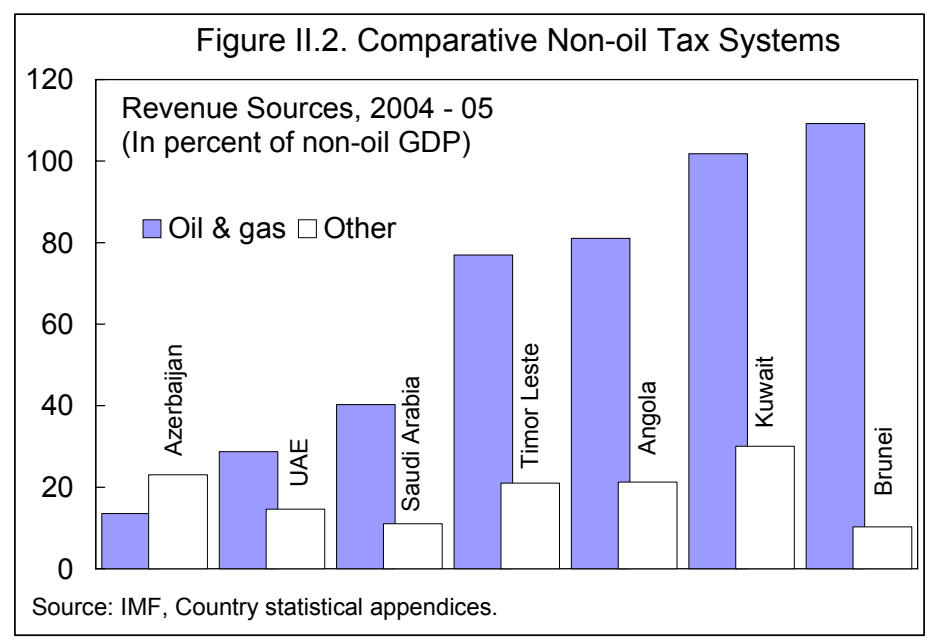
Venezuela and Nigeria). Unfortunately, there is very little empirical evidence about the comparative advantages of these different models of taxation.

\section{In Timor-Leste, the income tax base is narrow with the majority of large} taxpayers paying the minimum income tax. The minimum income tax (1 percent of turnover against which income tax is accredited) is designed to provide a simple means of broadening the tax net and is not meant to be a final tax for most businesses. However, around 64 percent of large taxpayers, generating 70-80 percent of domestic tax revenue, pay only the minimum tax. ${ }^{15}$ This suggests either compliance problems or very weak balance sheets.

\footnotetext{
${ }^{14}$ See Ebrill and others (2001), Chapter 16, which concludes that it "is appropriate to temper general support for the introduction of a VAT to smaller economies with a note of caution."

15 There are 45 taxpayers covered by the large taxpayer unit.
} 


\section{The 2005 laws on external and domestic investment include tax incentives and} concessions, adding a layer of complication with uncertain benefits. Studies indicate that investors generally assign a higher priority to a stable and transparent tax system with low rates than to complicated investment incentive schemes with partly negotiated relief. ${ }^{16}$ International experience suggests that the effectiveness of incentives in attracting new investment is questionable and at times the costs may even exceed the level of new investment generated. ${ }^{17}$ In addition, and importantly for Timor-Leste, incentives increase the complexity of the tax system and thereby increase the compliance and enforcement burdens on the administration and business. In the case of Timor-Leste, although critical provisions of the laws are ambiguous, no tax rulings have been issued nor have the mechanisms for clarifying the provisions been established. ${ }^{18}$ Finally, the discretionary negotiating powers accorded in the Timor-Leste laws (in the form of "special investment agreements" that enable the government to establish "special legal regimes" for individual investors) is an invitation to foreign investors to "go shopping" for generous relief and increases the incentives for corruption.

\section{Notwithstanding the} relatively simple design of the tax system in Timor-Leste, it appears not sufficiently so in relation to the level of administrative and taxpayer capacity. Figure II. 3 shows the time devoted to tax compliance in Timor-Leste.

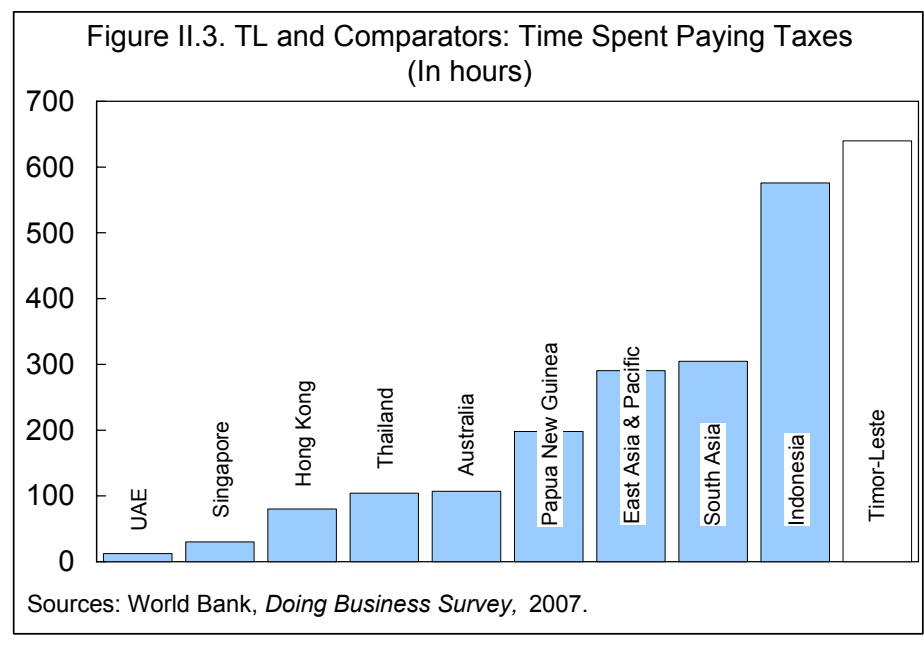

\footnotetext{
${ }^{16}$ McKinsey (2003) shows that direct incentives to FDI such as tax holidays, import duty exemptions, and investment allowances did not have a major impact on FDI flows in developing countries.

${ }^{17}$ See Zee et. al (2002). The benefits to the foreign investor of the tax incentives may also be undone when profits are repatriated, being then entirely offset by an increased tax the resident country. Tax incentives then simply transfer of tax revenues to the residence country, unless a double tax agreement with the residence country provides for tax sparing (there are currently no such agreements in place with Timor-Leste).

${ }^{18}$ For example, it is unclear whether provisions regarding tax relief for permanent workers is an allowance or a tax credit nor which taxes are affected by the provisions providing tax exemption for reinvested profits.
} 


\section{Issues To Consider Regarding Non-Oil Tax Systems: The Case of Timor-Leste}

\section{Impact on Growth of Abolishing or Cutting Back Taxes}

39. Tax elimination or cuts could boost private activity, primarily by reducing efficiency loss. In general, the higher is the level of taxation, the larger is the efficiency loss created. That is, private economic agents' allocative decisions will be different from those that would be made if the same amount of revenue were raised in a way that did not affect their decisions at the margin. However, while there is much evidence of the distortionary impact of taxes on income, in particular, pointing to a negative relationship between the level of taxation and the level of output, empirical evidence of the impact of various aspects of tax policy on growth has so far been mixed (Tanzi and Zee, 1997). This is mainly driven by the fact that the effects of taxation on growth depend not only on the level and structure of taxation but also on how the tax revenue is spent (i.e., the composition of public expenditure) and on how taxes affect the overall budgetary balance. At least for the OECD, though, there is evidence that taxes on income, but not taxes on consumption, do tend to reduce growth rates (Kneller and others, 1999).

40. For Timor-Leste, the effect of tax cut, as a fiscal stimulus, could be greater than in other countries. Tax cuts would be financed by oil/gas revenues, rather than through spending cuts or borrowing, since the sustainable income from envisaged oil wealth is enough to cover the government expenditures in the foreseeable future. Thus any Ricardian effects - that the impact of today's tax cut is limited by the private sector's expectation that it will be met by increased taxation in the long term - are likely to be limited.

\section{At the same time, the government should remain vigilant to mitigate any} resulting inflation and associated real exchange rate appreciation. Any tax reductions would have to be considered in conjunction with increases in government spending. Investment spending is likely to have a high import content, which would reduce the inflationary impact. However, a consumption stimulus could increase wage levels, especially in high skilled sectors and services where supply is very limited. Higher inflation rates, relative to competitor countries, could lead to a real exchange rate appreciation, reducing the competitiveness of the tradable sector, and making it more difficult to diversify the economy.

\section{Fiscal Insurance and Reduced Volatility in Government Revenue}

\section{Abolishing the non-oil tax system would remove a useful discretionary fiscal}

policy instrument. If oil prices fall sharply or if production is disrupted at Timor-Leste's one operating oil-and-gas field, then non-oil tax revenue may be needed to finance critical government expenditure, particularly for social programs or capital projects that cannot be easily or quickly cut. Doing away completely with the present non-oil tax system would reduce the strength of the automatic and potential stabilizers that are built-into the present fiscal system (including through progressive income and wage taxes, and consumption taxes). While the stabilizing or financing properties of the current domestic tax system may 
be fairly week, given existing low non-oil revenue contribution to total revenue, these could grow in importance with the further development of the economy. Thus, retaining the tax system, even if at very low rates, could provide insurance for spending programs as rates could be raised (up to a limit) should oil revenues decline.

43. Reliance on oil revenue can make budgetary planning and the efficient use of public resources difficult. International oil prices have shown a high degree of volatility and unpredictability, posing challenges for fiscal policy design and management. Non-oil tax revenue is likely to be less volatile than oil revenues. Thus, the maintenance of even a small domestic tax base is likely to compliment the government's long-term fiscal sustainability and intergenerational equity guideline.

\section{Administrative Considerations}

44. If abolished, a tax system could be costly to reestablish should it be needed at a future date. Establishing a tax system from scratch would required investments in basic physical and human capital, in addition to educating taxpayers unfamiliar with paying taxes. It may therefore be easier to maintain tax rates at very low levels and raise them in times of need. Abolishing the present tax administration could also complicate the introduction of new taxes that the authorities may contemplate in the future, including for non-tax (e.g., regulatory) reasons, such as land or property taxes.

\section{Equity Considerations}

45. There may be important equity implications of removing non-oil taxes. With regard to vertical equity (redistribution among individuals with different levels of income), the main instruments comprise existing and planned expenditure policies, as well as the progressive income tax system in combination with sales, excise, and service taxes (presumably with an incidence mainly on the well-off). Doing away with the domestic tax system may reduce the overall fairness of the fiscal system.

\section{Enhancing Accountability of Government Activities}

\section{Political economy considerations suggest that significant levels of non-oil} taxation may help enhance accountability. ${ }^{19}$ An important political economy argument in favor of maintaining a non-oil taxation system is that higher non-oil tax levels generally induce taxpayers to demand higher accountability of their governments, in turn leading to less wasteful use of public resources and less corruption (Isham and others, 2003). ${ }^{20}$ In the

\footnotetext{
${ }^{19}$ Ross (2001); Isham and others (2003); Bevan and others (1999); Robinson and others (2003); and Katz and others (2004).
} 
case of Timor-Leste, where non-oil taxes constitute a relatively small part of total revenue, it is not clear how binding this consideration would be.

\section{However, some have argued that resource revenues should be distributed} directly to the population to overcome poor institutional quality and enhance accountability. With weak institutional quality and poor governance liable to waste resources and vulnerable to corruption, some authors argue that distributing resource wealth directly to the population is more efficient and conducive to long-term growth. Individuals might then spend the windfall more efficiently than the public sector (Sala-i-Martin, 2003). This would also leave the authorities needing to levy non-oil taxes to raise the revenue they need, potentially increasing accountability, although non-oil tax revenue may also be spent inefficiently. $^{21}$

\section{Experience With Tax Policy Reform}

\section{Lessons from successful reforms in other countries at a similar stage of} development maybe important for Timor-Leste. While the need for non-oil tax reform in Timor-Leste is not a financial issue, considerations to keep in mind from lessons learned in other low-income countries that reformed the tax system include:

- Successful tax reforms have often involved reducing high marginal rates of tax and moving away from fine-tuned tax structures, toward lower and more uniform rates and simpler structures.

- $\quad$ Major reforms in tax design and administration take time to implement. New or amended legislation is often required and procedures frequently need modification (Daniel et. al, 2006).

- $\quad$ The introduction of a VAT has often been at the center of the tax policy and tax administration reform efforts. However, as noted above, enthusiasm for a VAT must be tempered in a small country like Timor-Leste.

- $\quad$ Effective withholding systems are vital for success in income taxation. Reforms that have failed to extend tax withholding much beyond the incomes of civil servants and

\footnotetext{
20 This argument is based on studies of the evolution of democratic institutions in England and France, where demand for representation in government was found to have arisen in response to the state's attempts to raise taxes. Empirically, this effect has been demonstrated for Kuwait and Qatar (Crystal 1990), and Jordan (Brand, 1992). Evidence to the contrary has been presented by Waterbury (1994).

21 Sala-i-Martin (2003) argues that one way to reduce a wasteful use of resource revenue would be to distribute all the revenues to the people and require government to rely on normal fiscal principles to determine appropriate levels of taxation and expenditure since this distribution would create the right incentives for governance. In the case of state government of Alaska, in the United States, the authorities pay out a dividend from the Permanent Fund, that accumulates the oil revenue, to residents every year.
} 
the very largest business firms have generally led to disappointing results. At the same time, more focus on voluntary compliance and self-assessment over the medium-term contributes to reducing administrative costs.

- $\quad$ The chances for successful tax reform are considerably enhanced when reform efforts go beyond mere changes in tax policies, to fundamental reform of the broader tax system, including also measures to simplify tax administration and improve compliance. $^{22}$

- $\quad$ The chances for successful comprehensive reform tend to be the greatest when reform is not initiated in response to a severe short-term fiscal crisis. Introduction of tax reform in response to acute fiscal crisis increases the likelihood that the government will try to implement the reform in the shortest possible period in the midst of strong resistance from the public, so that the quality of the design and implementation of the reform may suffer.

49. The Timor-Leste authorities are also keen to learn from the experience of successful tax systems in the region. In line with the global trends, many of the rapidly growing countries in Asia have shifted their tax base away from trade taxes, there has been some effort to lower income tax rates, and there has been a large increase in the application of consumption taxes, particularly the Value-Added Tax (VAT). ${ }^{23}$

\section{E. Conclusions: Possible Tax Policy Reform for Timor-Leste}

\section{Significant Room for Tax Cuts}

- $\quad$ Timor-Leste has enough fiscal space to reduce the tax burden, since sustainable income from envisaged oil wealth is expected to exceed government spending in the foreseeable future. ${ }^{24} \mathrm{~A}$ tax cut could eventually enhance economic growth by invigorating private activity by reducing the distortions introduced by the tax system and increasing domestic demand.

\footnotetext{
${ }^{22}$ See, for instance, Stepanyan (2003).

${ }^{23}$ Keen and Simone (2004) describe global trends in tax policy during the 1990s.

${ }^{24}$ While on the budget's "commitments" basis expenditure for 2006/07 is projected to be close to the sustainable spending level, including domestic taxes, ongoing expenditure execution problems are likely to result in a much lower level of spending. Nonetheless, this does raise issues for future budgets (see 2006 Article IV Consultation Staff Report).
} 
- However, retaining a tax structure and some level of non-oil tax revenue would be prudent, to provide insurance against a steep fall in oil and gas revenues and to provide a degree of revenue stability. ${ }^{25}$ Figure II.4 shows the large fluctuation in projected oil revenue in Timor-Leste over the past year, as oil prices have risen and production schedules have been revised.

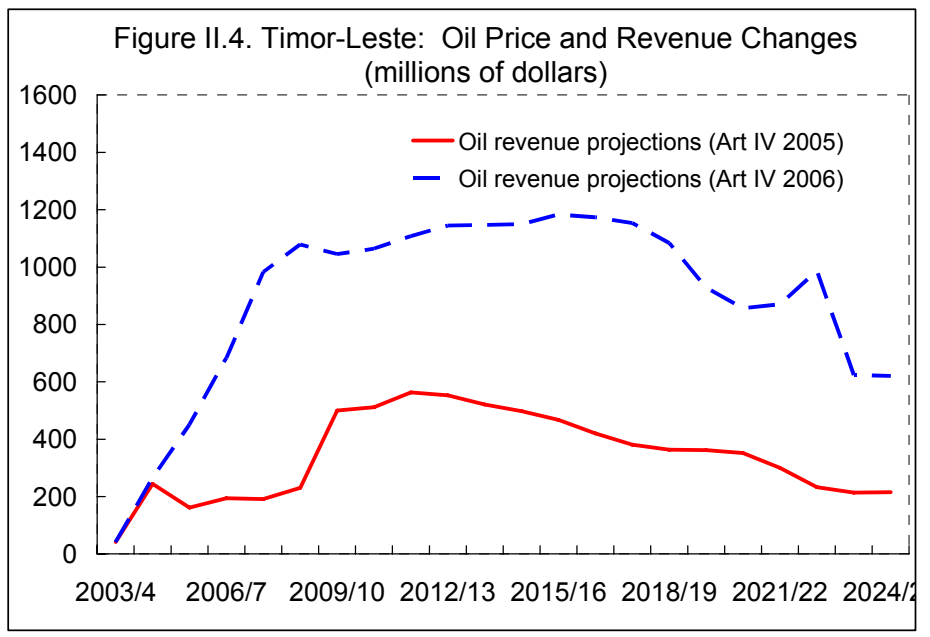

\section{Some Possible Elements of Tax Reform for Timor-Leste ${ }^{26}$}

- Significantly reduce personal and corporate income tax rates. As noted earlier, reducing income tax rates could generate large efficiency gains and would serve as an investment-friendly measure. Figure II.5 suggests that this measure would be in line with regional (and global) trends towards lower corporate and personal income tax rates.

Particular attention should be paid toward restructuring the income tax base with the view of lowering the tax burden on

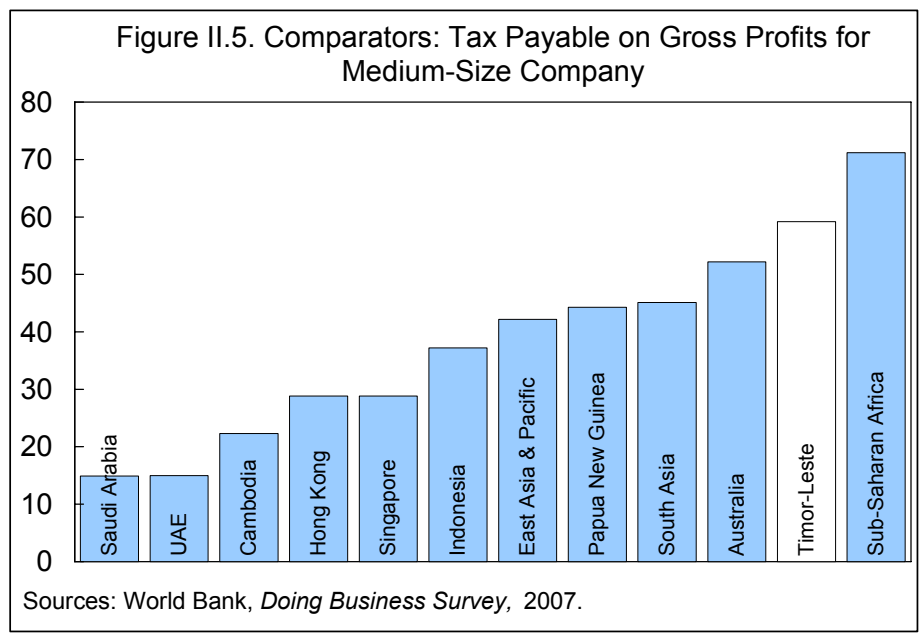
capital income.

- Tariff and sales tax rates could also be reviewed, while the introduction of a VAT would at best be a long-term objective. In a small open economy like Timor-Leste's, with little domestic production, there is little economic difference between a consumption tax and the current tariff system. While acknowledging the general benefits of a VAT (see Ebrill, 2001), the current tariff system is administratively

${ }^{25}$ Further in depth study is needed to determine the appropriate structure and desired level of taxation.

${ }^{26}$ These proposals are preliminary and an IMF technical assistance mission, planned for January 2007, will provide more detailed recommendations. 
simple and any move toward a VAT is unlikely to deliver significant efficiency benefits and a high threshold for registration would also have to be instituted to maintain the systems simplicity, potentially narrowing the tax base. The more immediate option for reform could be a review of the tariff and sales tax rates, with a view to reducing and simplifying rates.

- If required at a later date, the authorities could relatively easily raise non-oil tax revenue by increasing tax rates. If tax rates were set considerably lower relative to its neighbors, rather than abolishing them, then Timor-Leste would at least retain scope for increasing rates, if required, without significantly raising concerns over private sector competitiveness.

- $\quad$ To the extent that the tax system is simplified and nominal rates reduced, any arguments for distortionary tax incentives could be significantly diminished. In an envisaged reform, the principle of simplifying tax structures should be paramount, particularly given low administrative capacity available. Simplification and rate reductions can be mutually reinforcing and could even improve compliance rates (as avoidance costs decline). In that light, there would be room to revisit the incentives set out in the investment laws.

- $\quad$ Raising minimum tax thresholds could exempt many small taxpayers from the tax net, which would reduce collection reduce costs. This must be carefully designed to avoid over concentration of the tax net and the perception that remaining taxpayers are being unfairly penalized. Nonetheless, it could encourage small and medium-sized enterprises and the disincentive for growing into the tax net would not be too great if tax rates were generally low.

- $\quad$ Even with the above reforms, the authorities should continue to improve tax administration, to make it as efficient and effective as possible. Focus on administrative reforms is important to reduce compliance costs, particularly through improved taxpayer awareness and education as many, particularly small, taxpayers have limited accounting capacity. Given that most non-oil revenue will continue to be collected at the border, priority should also be accorded to modernization of the customs administration, particularly the automation of import clearance procedures, training for customs officers to curtail undervaluation and misclassification, and increasing the capacity to detect and investigate smuggling and revenue evasion. 


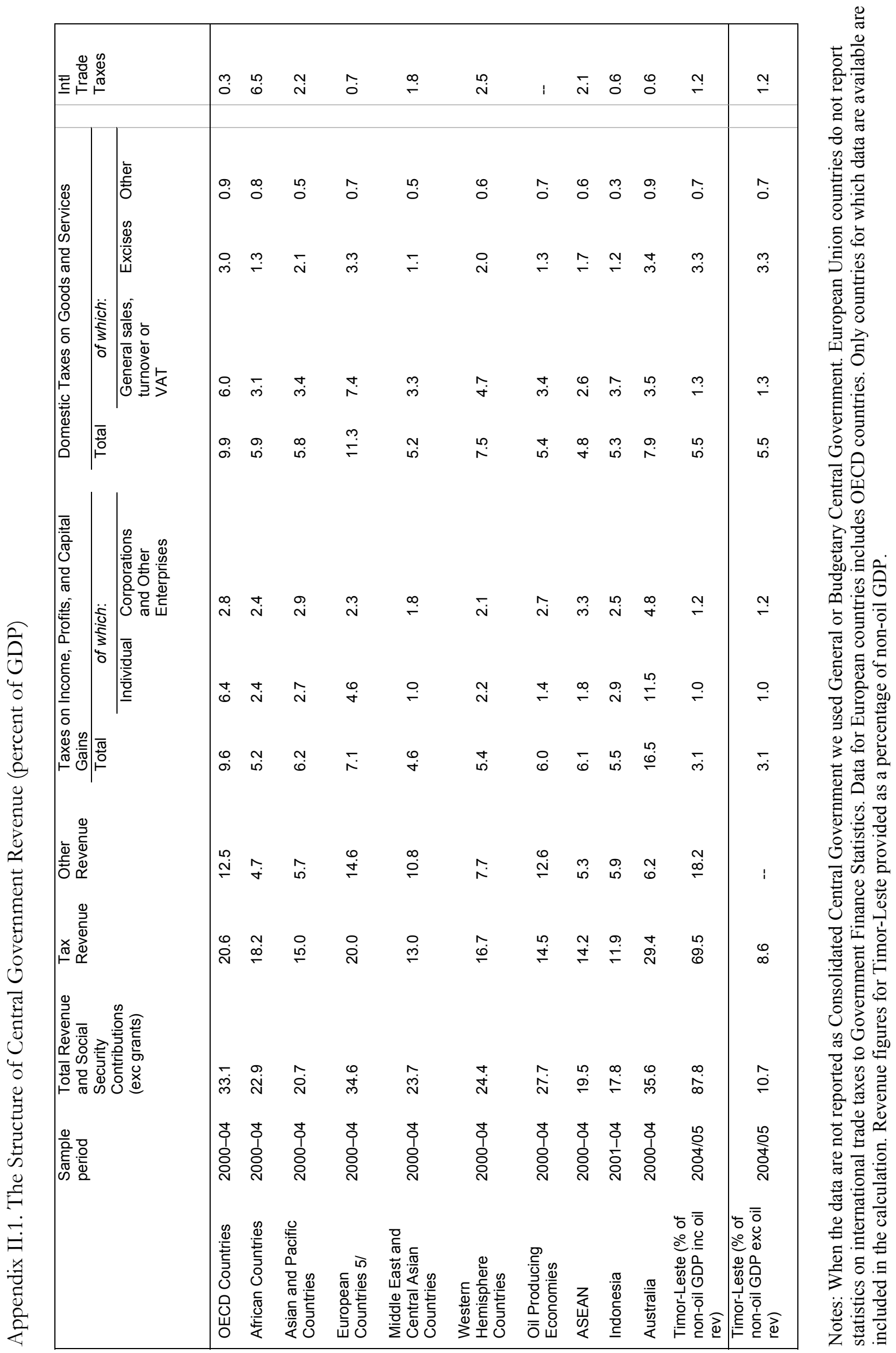




\section{References}

Bartch, U., Katz, M., Malothra, H., and Cuc, M., 2004, "Lifting the Oil Curse, Improving Petroleum Revenue Management in Sub-Saharan Africa" (Washington, D.C.: International Monetary Fund).

Bevan, D., P. Collier and J. Gunning, 1999, "The Political Economy of Poverty, Equity, and Growth: Nigeria and Indonesia," A World Bank Comparative Study (Oxford: University Press).

Brand, L.A., 1992, "Economic and Political Liberalization in a Rentier Economy: The Case of the Hashemite Kingdom of Jordan” (Bloomington: Indiana University Press).

Crystal, J., 1990, "Oil and Politics in the Gulf: Rulers and Merchants in Kuwait and Qatar" (New York: Cambridge University Press).

Daniel, J., 2003, “Hedging Government Oil Price Risk” in Fiscal Policy Formulation and Implementation in Oil Producing Countries, ed. by J. Davis, R. Ossowski, and A. Fedelino (Washington, D.C.: International Monetary Fund).

—, M. Fouad and C. Rijckeghem, 2006, Fiscal Adjustment for Stability and Growth (Washington, D.C.: International Monetary Fund).

Ebrill, L., M. Keen, J.P. Bodin, and V. Summers, 2001, The Modern VAT (Washington, D.C.: International Monetary Fund).

Isham, J., M. Woolcock, L. Pritchett, and G. Busby, 2003, “The Varieties of Resource Experience: How Natural Resource Export Structures Affect the Political Economy of Economic Growth," Harvard University, Middlebury College, and World Bank.

Katz, Menachem, B. Ulrich, H. Malothra, and M. Cuc, eds., 2004, Lifting the Oil Curse, Improving Petroleum Revenue Management in Sub-Saharan Africa (Washington, D.C.: International Monetary Fund).

Keen, Michael and A. Simone, 2004, "Tax Policy in Developing Countries: Some Lessons from the 1990s and Some Challenges Ahead" in Helping Countries Develop: The Role of Fiscal Policy, ed. by S. Gupta, B. Clements, and G. Inchauste (Washington, D.C.: International Monetary Fund).

Kneller, R., F. Bleanney, and N. Gemmell, 1999, "Fiscal Policy and Growth: Evidence From OECD Countries," Journal of Public Economics, Vol. 74, Issue 2, pp. 171-90. 
McKinsey, 2003, "New horizons: Multilateral Company Investment in Developing Economics," McKinsey reports.

Robinson, J. A., R. Torvik, and T. Verdier, 2003, "Political Foundations of the Resource Curse," DELTA Working Paper No. 2003-33.

Ross, M. L., 2001, “Does Oil Hinder Democracy?” World Politics, Vol. 532, pp.325-61.

Sala-i-Martin, X. and A. Subramanian, 2003, "Addressing the Natural Resource Curse: An Illustration From Nigeria," IMF Working Paper No. 03/139 (Washington, D.C.: International Monetary Fund).

Stepanyan, V., 2003, "Reforming Tax System: Experience of the Baltics, Russia, and Other Countries of the Former Soviet Union," IMF Working Paper No. 03/173 (Washington, D.C.: International Monetary Fund).

Tanzi, V. and H. Zee, 2000, "Tax Policy for Emerging Markets: Developing Countries," National Tax Journal, Vol. 53, No. 2, pp. 299-322.

Waterbury, J., 1994, "Democracy Without Democrats? The Potential for Political Liberalization in the Middle East" in Democracy Without Democrats? The Renewal of Politics in the Muslim World, ed. by Salamé, G. (London; New York: I.B. Tauris).

Zee, Howell, Janet Stotsky, and Eduardo Ley, 2002, "Tax Incentives for Business Investment: A Primer for Policy Makers in Developing Countries," World Development, Vol. 30, No. 9, pp. 1497-1516. 


\section{Petroleum Fund Investment Strategy ${ }^{27}$}

\section{A. Introduction}

50. The Timor-Leste Petroleum Fund (TLPF) was established in August 2005 with the enactment of the Petroleum Fund law. The principles of the TLPF law emphasize transparency and governance and establish a guideline for saving for future generations, withdrawal rules, reporting, and, the scope of asset investment. The investment rules imply a conservative and low risk approach to management of the TLPF's assets. All the assets are currently invested in U.S. government bonds and managed passively to track the Merrill Lynch US government bond index.

51. Transparency and capacity constraints informed the choice of a simple and conservative investment strategy, versus a strategy pursuing higher returns by immediate diversification. Local staff at the Banking and Payments Authority (BPA) are in charge of the operational management of the assets with support from foreign advisors, reflecting the principle that the TLPF should stay under Timorese management. The law establishes the aim of building local capacity over external managers. The law permits an initially small amount of diversification and details the range of qualifying instruments after five years (Box III.1).

\section{Against this background, this paper discusses the current direction of TLPF} asset management and issues that might arise with eventual asset diversification. In particular, we look at the experiences of other commodity funds and analyze these with standard portfolio theory. Fixed-income, predominantly sovereign, assets tend to dominate the portfolio composition of other commodity funds, especially during their start-up period. Therefore, the current asset allocation of the TLPF is in line with that of other commodity funds. As an annex to this discussion, using simple mean-variance portfolio theory we conduct some numerical exercises examining some possible future optimal portfolios for the LTPF. The exercise will highlight potential benefits from eventual diversification as well as elements of needed capacity building prior to manage more diversified portfolio.

53. The rest of the paper is organized as follows. Section B summarizes asset allocations among major commodity funds. In Section $\mathrm{C}$ we discuss capacity constraints that may affect asset diversification and the use of external managers. Section D presents some concluding thoughts. Annex III.I shows the results of a quantitative optimal portfolio exercise and its sensitivity to measurement errors.

\footnotetext{
${ }^{27}$ Prepared by Hiroko Oura.
} 


\section{Box III.1. Petroleum Fund in Timor-Leste}

The Petroleum Fund (TLPF) was formed by the Petroleum Fund Law, promulgated on August 3, 2005. The TLPF began operations in September 2005 with an opening balance of $\$ 205$ million, increasing to $\$ 847$ million by September 2006 . The Banking and Payments Authority (BPA) has responsibility for the TLPF's operational management.

In line with the requirements of the TLPF law to invest in qualifying sovereign bonds with investment performance measured against the Merrill Lynch 0-5 year U.S. government bond index, all assets are invested in short and medium-term U.S. government bonds. The TLPF investment portfolio has followed the benchmark closely with only a few basis points difference in yield, well within the 25 basis points margin specified in the law. The law commits to the current investment strategy for at minimum the initial five years. However, it also allows using a maximum 10 percent of assets for other types of investments, which should help capacity building at the BPA.

\section{B. Asset Allocation in Oil/Commodity Funds}

\section{In this section, we look at the asset allocation of major commodity funds to see} how the allocation at the TLPF compares. In addition, we briefly discuss the asset allocation at some selected institutional investors as a reference to see how commodity funds as a group compare to other long-term investors. ${ }^{28}$ Table III.1 summarizes asset allocation patterns in a range of funds.

\section{Most commodity funds reviewed operate with a smaller range of assets (and} mainly fixed income) than long-term institutional investors. The Norwegian Petroleum Fund, the largest reported commodity fund in terms of nominal assets, is also one of the most mature and diverse; nonetheless, it does not invest in real estate and other alternative investments. ${ }^{29}{ }^{30}$ One exception today to the tendency toward a less diversified portfolio among the commodity funds is the Alaska Petroleum Fund Corporation. Most institutional investors, in comparison, are highly diversified and their investments cover a range of asset

\footnotetext{
${ }^{28}$ It is natural to see differences as each type of fund can have different investment objectives. However, the comparison can provide a good illustration about where, in the future, the TLPF could potentially move as its investment objective shifts more towards seeking better returns, not just securing minimum resources for the future generation.

${ }^{29}$ The Government Pension Fund was established in 2006 and consists of two parts: "The Government Pension Fund-Global," which is a continuation of the Petroleum Fund, and "The Government Pension Fund-Norway," which was previously known as the National Insurance Scheme Fund.

${ }^{30}$ A number of oil funds, such as Brunei and Kuwait, do not report on the size or structure of their assets.
} 
classes, including real estate and hedge funds. Among all funds there is a general preference to place assets abroad, mainly to allay fears about appreciation of the domestic currency.

Table III.1. Asset Allocation of Investment Funds

\begin{tabular}{|c|c|c|c|c|c|c|}
\hline \multicolumn{7}{|c|}{ Table III.1. Asset Allocation of Investment Funds } \\
\hline Oil/commodity Funds & $\begin{array}{l}\text { Total Assets } \\
\text { (in USD) }\end{array}$ & $\begin{array}{l}\text { Year } \\
\text { created }\end{array}$ & $\begin{array}{l}\text { Asset } \\
\text { Allocation }\end{array}$ & Benchmark & Performance & Strategy \\
\hline Azerbaijan State Oil Fund & $\begin{array}{l}964 \text { million } \\
\text { (end 2004) }\end{array}$ & 1999 & $\begin{array}{l}100 \% \text { fixed } \\
\text { income }\end{array}$ & $\begin{array}{l}3 \text { month LIBOR in } \\
\text { respective currency }\end{array}$ & & $\begin{array}{l}\text { Primary investments are bank deposits, money } \\
\text { market funds, bonds, and index funds. } 50 \text { percent } \\
\text { of total assets go to liquid assets, } 40 \text { percent goes } \\
\text { to securities including sovereign debt, US } \\
\text { agencies, debts issued by banks and corporate. } \\
\text { The rest are managed by two external managers. } \\
\text { Investing only in investment grade issuers and } \\
\text { securities. }\end{array}$ \\
\hline $\begin{array}{l}\text { Norway pension fund } \\
\text { (former petroleum fund) }\end{array}$ & $\begin{array}{l}199 \text { billion } \\
\text { (Sep. 2005) }\end{array}$ & 1990 & $\begin{array}{l}59 \% \text { fixed } \\
\text { income, } 41 \% \\
\text { equity (actual). }\end{array}$ & $\begin{array}{l}\text { Benchmark portfolio } \\
\text { (equity }(40 \%) \text {, fixed } \\
\text { income }(60 \%))\end{array}$ & $\begin{array}{l}8.9 \% \text { in } 2004 . \\
0.49 \% \text { excess } \\
\text { return (net of } \\
\text { management } \\
\text { cost) over } \\
\text { benchmark. }\end{array}$ & $\begin{array}{l}\text { MoF sets benchmark portfolio for Norges Bank } \\
\text { ( } 40 \% \text { equity ( } 50 \% \text { Europe), } 60 \% \text { bonds ( } 55 \% \\
\text { Europe, } 35 \% \text { America, } 10 \% \text { Asia/Oceania)). } \\
\text { Managed by internal and external managers. } \\
\text { Engaged in active management and equity } \\
\text { investments since } 1998.1 .5 \% \text { limit on expected } \\
\text { relative tracking error. Equity investment is usually } \\
\text { made in non-oil sector. }\end{array}$ \\
\hline $\begin{array}{l}\text { Alaska Permanent Fund } \\
\text { Corporation }\end{array}$ & $\begin{array}{l}33.2 \text { billion } \\
\text { (Feb. 2006) }\end{array}$ & 1976 & $\begin{array}{l}35 \% \text { US stocks, } \\
25 \% \text { US bonds, } \\
4 \% \text { non-US } \\
\text { bonds, } 18 \% \text { non- } \\
\text { US stocks, } 10 \% \\
\text { real estate, } 8 \% \\
\text { alternative. }\end{array}$ & $\begin{array}{l}\text { Aims real rate of } 5 \% \\
\text { per year long-term. }\end{array}$ & $\begin{array}{l}8.7 \% \text { rolling } \\
\text { total returns } \\
\text { p.a. for } 1996- \\
2005 \text {. }\end{array}$ & $\begin{array}{l}\text { Started as an all bond fund. Legislation was } \\
\text { changed in } 1983 \text { to allow investments in stocks } \\
\text { and real estate with limits on their allocations. } \\
\text { Within the limit the board of the Fund sets the } \\
\text { asset allocation structure annually with input from } \\
\text { consultants. Internal managers focus on fixed } \\
\text { income instruments, and external managers focus } \\
\text { on other varieties of investments. }\end{array}$ \\
\hline $\begin{array}{l}\text { Kuwait Reserve Fund for } \\
\text { Future Generations }\end{array}$ & $\begin{array}{l}3.1 \text { billion } \\
\text { (end } \\
\text { FY2004/2005) }\end{array}$ & $\begin{array}{l}1976 \\
\text { (1960 for } \\
\text { General } \\
\text { Reserve } \\
\text { Fund) }\end{array}$ & -- & $\begin{array}{l}\text { Aims to exceed } \\
\text { standard composite } \\
\text { index for each } \\
\text { investment } \\
\text { categories on a 3- } \\
\text { year rolling average }\end{array}$ & -- & $\begin{array}{l}\text { Kuwait Investment Authority (KIA) was } \\
\text { established in } 1982 \text { to manage the funds of the } \\
\text { government (including RFFG, GRF, and other } \\
\text { moneys committed by the MoF). It invests in } \\
\text { diverse domestic/foreign instruments including } \\
\text { equity and fixed income (government and } \\
\text { corporate) for US, Canada, Europe, and Asia, } \\
\text { shares in Arab companies, investment in local } \\
\text { companies, American and Asian private equity, } \\
\text { real estate, and hedge funds. }\end{array}$ \\
\hline $\begin{array}{l}\text { Chile Copper Stabilization } \\
\text { Fund }\end{array}$ & -- & 1985 & -- & -- & -- & $\begin{array}{l}\text { Resources are treated as international reserves } \\
\text { and are managed by the central bank. }\end{array}$ \\
\hline \multicolumn{7}{|l|}{ Reference funds } \\
\hline IMF staff retirement fund & $\begin{array}{l}4.7 \text { billion } \\
\text { (April } 30 \\
2005, \text { cash } \\
\text { plus } \\
\text { investments) }\end{array}$ & 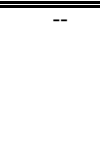 & $\begin{array}{l}60 \% \text { equity, } 23 \% \\
\text { debt security, } 7 \% \\
\text { cash, } 7 \% \text { private } \\
\text { equities, } 3 \% \text { real } \\
\text { estate. }\end{array}$ & 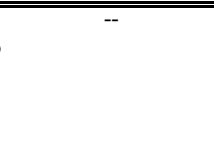 & 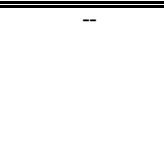 & $\begin{array}{l}\text { Diversified. No single investment exceeds } 5 \% \text { of } \\
\text { the net assets available for benefits. }\end{array}$ \\
\hline WB staff retirement plan & $\begin{array}{l}11.3 \text { billion } \\
\text { (end } 2004 \text { ) }\end{array}$ & -- & -- & $\begin{array}{l}\text { Composite based on } \\
\text { a standard } \\
\text { benchmark for each } \\
\text { instruments. }\end{array}$ & -- & $\begin{array}{l}\text { Strategic asset allocation of } 40 \% \text { fixed income, } \\
35 \% \text { equity ( } 19 \% \text { US, } 14 \% \text { developed markets } \\
\text { US, } 2 \% \text { EM), } 25 \% \text { alternative (hedge funds up to } \\
12 \% \text {, private equity up to } 12 \% \text {, real estate up to } \\
8 \% \text {. The allocation is reviewed every } 3-5 \text { years. }\end{array}$ \\
\hline $\begin{array}{l}\text { Harvard Management } \\
\text { Company }\end{array}$ & $\begin{array}{l}29.4 \text { billion } \\
\text { (June 2005) } \\
\text { General } \\
\text { Investment } \\
\text { Account }\end{array}$ & 1974 & $\begin{array}{l}\text { Can be different } \\
\text { from policy } \\
\text { portfolio. }\end{array}$ & $\begin{array}{l}\text { Composite based on } \\
\text { a standard } \\
\text { benchmark for each } \\
\text { instruments. }\end{array}$ & $\begin{array}{l}5 \text { year annual } \\
\text { rate of } 23.2 \% \\
\text { (policy portfolio } \\
\text { returned } \\
19.4 \% \text { ) }\end{array}$ & $\begin{array}{l}\text { Policy portfolio: } 15 \% \text { US equity, } 10 \% \text { foreign } \\
\text { equity, } 5 \% \text { EM equity, } 13 \% \text { private equity, } 12 \% \\
\text { absolute return funds, } 5 \% \text { HY securities, } 13 \% \\
\text { commodities, } 10 \% \text { real estate, } 11 \% \text { domestic } \\
\text { bonds, } 5 \% \text { foreign bonds, } 6 \% \text { inflation-indexed } \\
\text { bonds, }(5) \% \text { cash. Regularly reviewed. }\end{array}$ \\
\hline
\end{tabular}

Sources: Annual reports from Azerbaijan, Norway, Alaska oil fund, retirement fund for the IMF and the WB, and Harvard Management company. Web site for Kuwait Reserve Fund for Future Generations. IMF staff reports for Chile.

7. The commodity funds' typical focus on fixed income assets appears more visibly among smaller funds in smaller economies. In many cases, for example Chile, the assets under commodity funds are counted as a part of official international reserves and managed as reserves (namely, invested in short-term fixed income assets). In other cases, for example, Azerbaijan, the oil fund's financial assets are concentrated in liquid fixed-income assets, 
although these are not counted as official international reserves. Hence, constraints from reserve management policy are not the only reason for some funds to focus on fixed income assets.

\section{Investors With Common Objectives Have Varied Asset Preferences}

Investors with common preferences do not always opt for highly diversified portfolios. For example, pension funds that need to match specific long-term obligations pursue widely varying investment patterns (Global Financial Stability Report, IMF, September 2004). ${ }^{31}$ Some pension funds choose to invest primarily in equities, as they believe: (i) the long-run excess returns from equities will outweigh the short-term volatility; (ii) equity is a better inflation hedge than nominal bonds; and (iii) equities provide a better duration match with pension funds' liabilities owing to the lack of long-dated bonds. Other pension funds (e.g., the U.K. retailer Boots) invest primarily in bonds as they believe in reverse arguments, especially regarding the duration and risk match. ${ }^{32}$ Pension funds may also chose different strategies depending on the regulatory and tax environment and the design and the maturity of the fund; e.g., more mature funds, especially those with defined benefits, tend to increase the share of bonds in their portfolio to lower risk.

Thus, differences in views over the relative performance and characteristics of assets may be a dominant factor in portfolio choice, even for a group of institutional investors with common preferences and time-horizons.

\section{Initially, the Norwegian Petroleum Fund also followed the same investment} strategy as used for international reserves, resulting in the early heavily fixed-income based asset allocation. After its establishment in 1990 through the next seven years, the Norwegian Fund's assets were managed by the central bank following a strategy similar to that for its international reserves. The primary objective of central banks is to maximize the liquidity of their foreign reserves, subject to an acceptable level of return, which is contrary to fund managers who try to maximize return subject to an acceptable level of risk. ${ }^{33}$ Staff at the Norwegian central bank were, therefore, more familiar with fixed income assets. Investing in other assets required specialist training in those markets. By end-1997, the Fund's total assets had increased to $\$ 15.5$ billion. When the fund began to diversify its portfolio to include equities in 1998, external asset managers were chosen for the equity portion of the portfolio.

\footnotetext{
${ }^{31}$ This discussion points to the possibility of having diverse patterns for portfolio allocation even for a group of pension funds that share common investment objectives. The portfolios of commodity funds and pension funds may, of course, reflect different investment objectives and obligations.

${ }^{32}$ See John Ralf (2002) for a discussion of Boot's pension fund investment strategy.

${ }^{33}$ Cassard and Folkerts-Landau (2000).
} 
9. One other commodity fund that initially followed a conservative investment strategy before investing in riskier assets was the Alaska Permanent Fund Corporation. At its creation in 1976, the Alaska Fund was an all bond fund. In 1983, the relevant legislation was changed to allow investment in stocks and real estate, within specified limits. By then the total asset size had grown to about $\$ 3$ billion. As a state oil fund, it did not need to consider investment constraints related to foreign reserve management. Still, the Fund opted to invest only in safer bonds initially, suggesting that there were concerns regarding risks incurred in reaching for higher returns.

10. The current investment strategy of the Timorese TLPF is in line with other commodity funds, especially compared to smaller funds in smaller countries and to the start-up period for funds in Norway and Alaska. While a conservative asset management strategy involves opportunity costs, which may become of non-negligible size over time as the size of the fund grows, the management of the TLPF assets is evolving gradually in line with the capacity of the BPA. Although the TLPF was separated from the BPA reserves when it was created in August 2005 (and eventually separated from the BPA balance sheet in September 2006) the current strategy is similar to official reserve management strategies in many low income countries that emphasize liquidity, simplicity and low risk.

\section{Capacity Building and Diversification}

\section{Capacity constraints are an important factor in considering investment}

management strategies for the TLPF. Building financial knowledge to a level high enough to manage or monitor the management of a large and diversified fund in international capital markets is a significant task in any country. In Timor-Leste, this task is complicated by the absence of a complete commercial legislative framework, an effective court system, physical infrastructure, support services, and basic pension and insurance schemes. While some basic principles from finance theory are straightforward, their implementation requires significant amount of market knowledge and judgment to understand the full implications of even a simple investment strategy.

12. While external managers could substitute for some domestic capacity, policy and oversight capacity will still be required. The authorities are considering hiring reputable international organizations to act as potential external portfolio managers and to provide capacity building. However, the government will still need to elaborate its risk preferences and the performance of external managers will need to be monitored and evaluated by local staff in order to avoid moral hazard problems, namely, excessive risk-taking by external managers or transparency and ethics issues. Such monitoring will itself require capacity building in the local authority.

13. In considering what level of capacity is necessary before hiring external managers, the authorities need to decide what is the most desirable extent of delegation to external managers. A smaller degree of delegation requires more internal capacity 
building on asset management and can avoid moral hazard problems associated with external managers, but would potentially provide lower benefits from the use of external managers. It would also require a greater investment in time than the second option. A larger degree of delegation requires smaller internal capacity building and greater reliance on the external managers, but carries the risk that moral hazard problems materialize.

\section{Another factor to consider is the responsibility for choosing a benchmark}

portfolio. Managers, including external managers, are expected to perform as well as given benchmark indices. Total delegation that gives external managers freedom to choose a benchmark portfolio, against which the performance of the managers is evaluated, would not be optimal. The owner of the assets should be able to choose a benchmark portfolio and to measure the deviation of actual outcomes from the benchmark in terms of returns and any risk measure relevant to a particular component of the portfolio. Measuring and putting restrictions on risks will not be a straightforward task when dealing with complex financial markets.

\section{Case Studies: Benchmark Portfolio Choices}

In both Norway and Alaska the benchmark portfolio is chosen by the owner of the funds.

In Norway, the benchmark portfolio choice is made by the Ministry of Finance, although the central bank is the delegated manager of the Petroleum Fund's assets. Movements in a benchmark portfolio are the biggest (90 percent) factor determining overall returns (Annual Report, 2005). Thus, the choice of the benchmark portfolio, made by the local authority, is more important than how delegated managers maintain their balances.

In Alaska, the Board of Trustees reviews and adopts its asset allocation policy annually. In doing so, they hire external investment consultants, separate from the managers, to provide guidance on the capital market outlook on the basis of an industry-accepted capital asset pricing model. This method might be one way to complement the lack of capacity in benchmark portfolio selection, while mitigating any conflict of interest from delegating too much to external portfolio managers.

\section{Conclusions}

\section{The current investment strategy for the TLPF appears to be in line with that of} other government commodity funds, particularly during their initial start-up years. Nonetheless, given the potentially large opportunity costs, domestic capacity in asset and risk management should continue to be strengthened to allow some gradual portfolio diversification. This will also enable the authorities to decide whether and how best to use external managers for more sophisticated investment strategies. It is also appropriate that the authorities continue to consider alternative investment options under the existing mandate. 


\section{ANNEX III.I. ASSET DiverSIFICATION IN TIMOR-LESTE: Potential BENEFIT AND NEEDED CAPACITY}

\section{In this Annex, we try to quantify the potential benefit of asset diversification} based on standard mean-variance portfolio theory. Given existing capacity constraints in Timor-Leste, we will emphasize sensitivity issues with mean-variance optimal portfolio in practice, as it will indicate the amount of judgment needed to implement mean-variance portfolio theory-based investment strategy.

\section{Data and Set-up for the Exercise}

17. In this exercise, we focus on the class of indexed investments in equities and bonds and compute the optimal allocation between the two asset classes. ${ }^{34}$ Currently, Timor-Leste invests only in U.S. government bonds and tracks the Merrill Lynch U.S. government bond index with maturity from 0 to 5 years (MLB), which we use as benchmark bond portfolio. ${ }^{35} \mathrm{We}$ look for diversified equity portfolios that could be added to the bond benchmark among standard world equity indices, including S\&P 500, and the Morgan Stanley Capital International (MSCI) index for all countries, U.S., all country total return, and U.S. total return. ${ }^{36}$ In addition, we use 3-month U.S. treasury yields as a proxy for a safe asset return. Table III.2. (list of financial index) shows a list of indices and their abbreviations used in this paper.

\section{Crucial parameters to be estimated for this exercise are expected returns and the} covariance matrix for candidate assets and the rate of return for a safe asset. However, it is well known in the literature that estimates of the parameters have large errors, and, that the optimal asset allocation is highly sensitive to changes in the parameters, in particular to changes in expected returns (Cuthbertson and Nitzsche (2004), Best and Grauer (1991)). Therefore, sensitivity checks and obtaining a reasonable range estimate will become a crucial part of this exercise to establish robustness.

\footnotetext{
${ }^{34}$ We focus on indexed investment, as it is one of the simplest forms of investment and is in the capacity set at the BPA. Given that the BPA staff are currently following the bond index, following an equity index would add only small marginal costs. In addition, investment in stock indices linked to U.S. equities will not raise issues of foreign exchange-hedging.

${ }^{35}$ In this exercise, data for the 1-5 year index are used instead as they cover a longer time horizon. However, the correlation between these two series is quite high and it will not affect the output of the result significantly.

${ }^{36}$ The total returns index includes returns from dividend payments. Unlike a bond index, the equity index usually shows a smaller difference in returns between the total return index and price index, as returns from dividends are much smaller than that from price movements. (Price movements usually provide over 95 percent of total returns.) Because optimal asset allocation is quite sensitive to expected returns, as we will see, we consider both total returns and the price index for equity.
} 


\section{In what follows, we use simple averages from different sample size (5 years to} over 20 years) to estimate the parameters. Then, we compute the optimal portfolio for each estimate. In addition, as a rough sensitivity/robustness check, we will show the optimal allocation changes for hypothetical set of parameters.

Results of the Exercise

Table III.3 (descriptive statistics for annualized returns) shows a summary of estimated parameters and corresponding estimates for optimal equity holdings (market portfolio) and its expected return and standard deviation. ${ }^{37}$

- Benefits. In some cases, the potential benefits from diversification clearly appear as the optimal portfolio gives the higher expected return for a smaller standard deviation compared to the benchmark MLB (for example, MSCI all country index for any time horizon). This is mainly owing to the fact that equity and bond returns are little or negatively correlated and offset each other's volatility, while higher average returns from equity increases the portfolio's return. Although such a characteristic does not always hold for an optimal portfolio with other parameter set (for example, MSCI total gross return for over 10 years of horizon), it is the clearest case for seeing the potential benefit of diversification.

- Even when the optimal portfolio accompanies higher risk, it is compensated by better returns compared to the benchmark MLB. The Sharpe ratio, a risk-adjusted performance measure, is higher for all the candidates for the optimal portfolio than the benchmark, implying the increase in the expected return from diversification is higher than the increase in risks.

- However, a glance at the descriptive statistics for each index shows the time-variant nature of all the parameters. Bond and safe asset returns trend down as the rate of inflation declines. Equity returns also trend down, but estimates from the shorter period are strongly affected by business cycle factors. Furthermore, the co-movement of bonds and equities changes signs to negative from positive, indicating changes in asset market structure are a dominant factor in asset pricing.

\footnotetext{
${ }^{37}$ Mean-variance portfolio theory shows that optimal allocation across risky assets does not rely on allocation to safe assets nor risk-tolerance of an investor. The optimal allocation across risky assets is called market portfolio, and given as a tangency point between the mean-variance efficient frontier and capital market line, showing various allocations for safe and risky assets. In our exercise, we simply take the market portfolio as the optimal portfolio for Timor-Leste, which implicitly assumes the risk-tolerance of the Petroleum Fund is the same as a representative investor in markets and Timorese asset managers share the same expectations as that of a representative investor.
} 
- It is interesting to see that the calculated optimal asset allocation on equity (market portfolio) is relatively stable at about 10 percent with ranges from 6 percent to 16 percent despite the varieties of parameter estimates. This is partly because we are focusing on indices, which have stable statistical properties, rather than individual stocks.

- Costs. The optimal portfolio is extremely sensitive to changes in some parameters, bond returns in particular, while changes in some other parameters do not have much of an impact. In particular, slightly lower bond returns, which are quite likely scenarios in line with recent history, shift the optimal portfolio significantly away from bonds. On the other hand, for the benchmark bond return, equity returns need to be very high to increase optimal equity holdings significantly. This sensitivity, in particular to changes in expected returns of assets, is consistent with the findings in Best and Grauer (1991).

Table III.1.1. Numerical example, sensitivity of optimal portfolio to changes in parameters

Benchmark parameters: $(10$ year average $) \mu \_$bond $=4.98, \mu \_\mathrm{MSCl}$ ustr $=10.38, \sigma \_$bond $=2.24, \sigma \_\mathrm{MSCl}$ ustr $=15.79, \rho=-0.21, r=$ 3.66. $\mathbf{w}^{*}$ _equity $=0.1$

\begin{tabular}{|c|c|c|c|c|c|c|c|c|c|}
\hline \multicolumn{2}{|c|}{ Correlation $\rho$} & \multicolumn{2}{|c|}{$\begin{array}{c}\text { Bond expected return } \\
\mu \_ \text {bond }\end{array}$} & \multicolumn{2}{|c|}{$\begin{array}{c}\text { Equity expected return } \\
\mu \_\mathrm{MSCl} \text { ustr }\end{array}$} & \multicolumn{2}{|c|}{ Bond volatility $\sigma \_$bond } & \multicolumn{2}{|c|}{$\begin{array}{c}\text { Equity volatility } \sigma \_\mathrm{MSCl} \\
\text { ustr }\end{array}$} \\
\hline$\rho$ & $\mathrm{W}^{*} \_$equity & $\mu \_$bond & $\mathrm{w}^{*}$ equity & $\mu \_$MSClustr & $\mathrm{W}^{*} \_$equity & $\sigma \_$bond & $\mathrm{w}^{*}$ equity & $\sigma \_$MSClustr & $\mathrm{w}^{*}$ equity \\
\hline-0.99 & 0.12 & 6.00 & 0.07 & 40.00 & 0.24 & 10.00 & 0.56 & 40.00 & 0.03 \\
\hline-0.50 & 0.11 & 5.50 & 0.09 & 20.00 & 0.17 & 6.00 & 0.37 & 25.00 & 0.05 \\
\hline-0.21 & 0.10 & 4.98 & 0.10 & 10.38 & 0.10 & 2.24 & 0.10 & 15.79 & 0.10 \\
\hline 0.00 & 0.09 & 4.00 & 0.21 & 6.00 & 0.05 & 1.50 & 0.06 & 10.00 & 0.20 \\
\hline 0.73 & 0.00 & 3.50 & 0.75 & 2.00 & 0.01 & 1.00 & 0.03 & 5.00 & 0.43 \\
\hline 0.99 & -0.15 & 3.40 & 1.80 & 0.00 & -0.03 & 0.50 & 0.01 & 2.00 & 0.75 \\
\hline
\end{tabular}

- This sensitivity of the optimal portfolio to different parameter estimates implies that there could be potentially large costs from choosing an inappropriate portfolio owing to estimation error or time-varying nature of the parameters. The question is how large the loss of returns and/or increase of risks could be.

- Charts 1-4 show scenarios with different parameter values originally based upon the estimate using 10 years of data. Each chart shows the paths of cumulative expected (gross) return and \pm 1.5 standard deviation band with three different portfolios: (1) optimal portfolio for the parameter set in the scenario; (2) 10 percent equity and 90 percent bonds (the optimal portfolio for the estimates with 10 years data); and (3) 100 percent bonds (benchmark). Since parameters are annualized, the time scale is in years.

- The largest difference in expected returns between the optimal portfolio for each scenario and benchmark or 10 percent equity portfolio arises in the lower bond return scenario as it gives much larger optimal shares for equities ( 40 percent) than the other three scenarios. Therefore, in terms of opportunity cost (loss in expected returns) of maintaining fixedincome heavy portfolio, the cost will be much higher in an environment with lower bond yields and higher equity returns. 
- However, we should bear in mind that the appropriate opportunity cost measure should be adjusted for increases in risk. For instance, in a short time horizon of a few years, the \pm 1.5 standard deviation band of an equity heavy portfolio can perform worse than that of the bond-only portfolio even in the scenario where it is the optimal portfolio. The increase in risk will be more significant if the outcome is more similar to that of other three scenarios.

\section{Implications of the Exercise}

20. This time-varying nature of the parameters implies that an investor's outlook over these parameters, namely the state of capital markets, will potentially become a crucial factor influencing the optimal portfolio choice. In fact, some market practitioners try to combine the views of a manager about expected returns and correlations with historical based estimates in an explicit manner following Bayesian inference (Black and Litterman, 1992). In any case, a good asset manager needs to have good understanding of the state of the world economy, how world capital market works, and a reasonable outlook over the investment horizon under his/her responsibility. This suggests that the Timorese authorities need to build significant capacity in this area before moving to diversify.

21. It should be noted that the quantitative exercise in this section of the paper is not to recommend any particular portfolio for the TLPF. Rather, it introduces a theoretical framework that can be a good starting point for approaching the issue and highlighting some specific areas for additional capacity building to strengthen management of the TLPF. In addition, as noted in Campbell and Viceira (2001), it is well known that some theoretical results on asset allocation are counter-intuitive, and financial advisors in practice often deviate and recommend more intuitively convincing allocations. Therefore, the actual optimality of the results from any quantitative exercise should be carefully cross-checked with the ad-hoc intuition of an investor. This will add another dimension to the capacity building required before diversification.

22. While there are potential benefits from diversification, implementation requires a fair amount of judgment based upon a strong understanding of financial markets, even to decide a relatively simple investment strategy. 
Table III.I.2. List of financial index and their acronyms.

\begin{tabular}{|c|c|}
\hline$\overline{M L B}$ & Merrill Lynch US government bond index with maturity $1-5$ years \\
\hline $\mathrm{MSCl}$ & Morgan Stanley Capital International Inc \\
\hline $\mathrm{MSCl}$ all country & $\begin{array}{l}\mathrm{MSCl} \text { equity index (value weighted) including equities from } \\
\text { developed markets and emerging markets }\end{array}$ \\
\hline $\begin{array}{l}\mathrm{MSCl} \text { all country total } \\
\text { return, gross }\end{array}$ & $\begin{array}{l}\mathrm{MSCl} \text { total return equity index (value weighted) including } \\
\text { equities from developed markets and emerging markets }\end{array}$ \\
\hline S\&P 500 & US equity \\
\hline $\begin{array}{l}\text { MSCI US total return, } \\
\text { gross }\end{array}$ & $\begin{array}{l}\mathrm{MSCl} \text { total return equity index (value weighted) including } \\
\text { equities from US }\end{array}$ \\
\hline UST 3M & US treasury yield with 3 month maturity, proxy for safe assets. \\
\hline
\end{tabular}


Table III.I.3. Descriptive statistics for Annualized Monthly Returns of Major Indices 1/

\begin{tabular}{|c|c|c|c|c|c|c|}
\hline & MLB & $\begin{array}{l}\mathrm{MSCl} \text { all } \\
\text { country }\end{array}$ & $\begin{array}{r}\mathrm{MSCl} \text { all } \\
\text { country total } \\
\text { return. aross } \\
\end{array}$ & S\&P 500 & $\begin{array}{l}\text { MSCI US total } \\
\text { return, gross }\end{array}$ & UST 3M \\
\hline $\begin{array}{l}5 \text { year (2001 Feb.-2006 Jan.) } \\
\text { Mean } \\
\text { Std. deviation } \\
\text { Correlation } \\
\text { Optimal portfolio (OP) } \\
\text { OP mean } \\
\text { OP std. dev. } \\
\text { Excess return over MLB 2/ } \\
\text { Sharpe ratio }\end{array}$ & $\begin{array}{r}3.86 \\
2.46 \\
\quad \ldots\end{array}$ & $\begin{array}{r}2.91 \\
14.93 \\
-0.52 \\
\mathbf{0 . 0 9} \\
3.78 \\
1.93 \\
-8 \\
0.86\end{array}$ & $\begin{array}{r}5.05 \\
14.97 \\
-0.52 \\
0.10 \\
3.98 \\
1.93 \\
12 \\
0.97\end{array}$ & $\begin{array}{r}-0.20 \\
14.86 \\
-0.54 \\
0.06 \\
3.63 \\
2.00 \\
-23 \\
0.76\end{array}$ & $\begin{array}{r}1.50 \\
15.04 \\
-0.54 \\
0.08 \\
3.68 \\
1.92 \\
-18 \\
0.81\end{array}$ & 2.12 \\
\hline $\begin{array}{l}10 \text { year (1996 Feb.-2006 Jan.) } \\
\text { Mean } \\
\text { Std. deviation } \\
\text { Correlation } \\
\text { Optimal portfolio (OP) } \\
\text { OP mean } \\
\text { OP std. dev. } \\
\text { Excess return over MLB 2/ } \\
\text { Sharpe ratio }\end{array}$ & $\begin{array}{l}4.98 \\
2.24\end{array}$ & $\begin{array}{r}6.91 \\
14.74 \\
-0.27 \\
0.08 \\
5.14 \\
2.09 \\
16 \\
0.71\end{array}$ & $\begin{array}{r}8.90 \\
14.77 \\
-0.27 \\
0.10 \\
5.38 \\
2.17 \\
40 \\
0.79\end{array}$ & $\begin{array}{r}8.55 \\
15.60 \\
-0.21 \\
0.09 \\
5.29 \\
2.21 \\
31 \\
0.74\end{array}$ & $\begin{array}{r}10.38 \\
15.79 \\
-0.21 \\
0.10 \\
5.54 \\
2.30 \\
56 \\
0.82\end{array}$ & 3.66 \\
\hline $\begin{array}{l}15 \text { year (1991 Feb.-2006 Jan.) } \\
\text { Mean } \\
\text { Std. deviation } \\
\text { Correlation } \\
\text { Optimal portfolio (OP) } \\
\text { OP mean } \\
\text { OP std. dev. } \\
\text { Excess return over MLB 2/ } \\
\text { Sharpe ratio }\end{array}$ & $\begin{array}{r}5.85 \\
2.37 \\
\quad \ldots\end{array}$ & $\begin{array}{r}8.02 \\
13.69 \\
-0.09 \\
\mathbf{0 . 0 7} \\
6.01 \\
2.33 \\
15 \\
0.90\end{array}$ & $\begin{array}{r}10.20 \\
13.71 \\
-0.09 \\
0.10 \\
6.27 \\
2.42 \\
42 \\
0.98\end{array}$ & $\begin{array}{r}10.22 \\
13.97 \\
-0.03 \\
0.09 \\
6.24 \\
2.46 \\
39 \\
0.95\end{array}$ & $\begin{array}{r}12.62 \\
14.12 \\
-0.03 \\
0.11 \\
6.62 \\
2.60 \\
77 \\
1.05\end{array}$ & 3.90 \\
\hline $\begin{array}{l}20 \text { year (1986 Feb.-2006 Jan.) } \\
\text { Mean } \\
\text { Std. deviation } \\
\text { Correlation } \\
\text { Optimal portfolio (OP) } \\
\text { OP mean } \\
\text { OP std. dev. } \\
\text { Excess return over MLB 2/ } \\
\text { Sharpe ratio }\end{array}$ & $\begin{array}{l}6.59 \\
2.54\end{array}$ & $\begin{array}{l}\cdots \\
\cdots \\
\cdots \\
\cdots \\
\cdots \\
\cdots \\
\cdots \\
\cdots\end{array}$ & $\begin{array}{l}\cdots \\
\cdots \\
\cdots \\
\cdots \\
\cdots \\
\cdots \\
\cdots \\
\cdots\end{array}$ & $\begin{array}{r}10.71 \\
15.28 \\
0.04 \\
0.08 \\
6.90 \\
2.66 \\
31 \\
0.84\end{array}$ & $\begin{array}{r}13.38 \\
15.35 \\
0.04 \\
0.11 \\
7.32 \\
2.87 \\
73 \\
0.92\end{array}$ & 4.67 \\
\hline $\begin{array}{l}\text { Whole sample } \\
\text { Mean } \\
\text { Std. deviation } \\
\text { Correlation } \\
\text { Optimal portfolio (OP) } \\
\text { OP mean } \\
\text { OP std. dev. } \\
\text { Excess return over MLB 2/ } \\
\text { Sharpe ratio } \\
\text { Observation (months } \\
\text { ending Jan. 2006) }\end{array}$ & $\begin{array}{l}0.76 \\
336\end{array}$ & $\begin{array}{r}7.81 \\
14.21 \\
0.01 \\
0.06 \\
7.97 \\
3.61 \\
-1 \\
0.78\end{array}$ & $\begin{array}{r}10.06 \\
14.23 \\
0.01 \\
0.11 \\
8.19 \\
3.66 \\
22 \\
0.83\end{array}$ & $\begin{array}{r}11.23 \\
15.01 \\
0.15 \\
0.09 \\
8.28 \\
3.85 \\
31 \\
0.81\end{array}$ & $\begin{array}{r}14.57 \\
15.02 \\
0.15 \\
0.16 \\
9.03 \\
4.23 \\
106 \\
0.92\end{array}$ & 5.15 \\
\hline
\end{tabular}

Footnote

$1 /$ Geometric animalization for expected returns

2/ In basis points. 
Chart1. Cumulative growth in Asset,

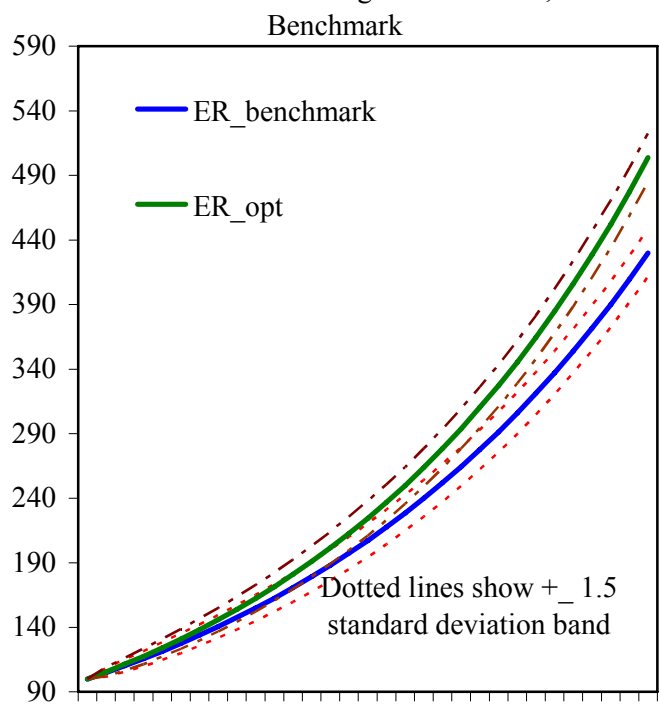

$03692 \leqslant 122^{\alpha} \hat{2} 3^{0}$

ER_bond $=4.98$, Stdev_bond $=2.24$, ER_Equity $=10.38$, Stdev_equity $=15.79$, Safe $r=3.66, W^{*}$ _equity $=10 \%$
Chart 2. Cumulative growth in Asset, lower bond return

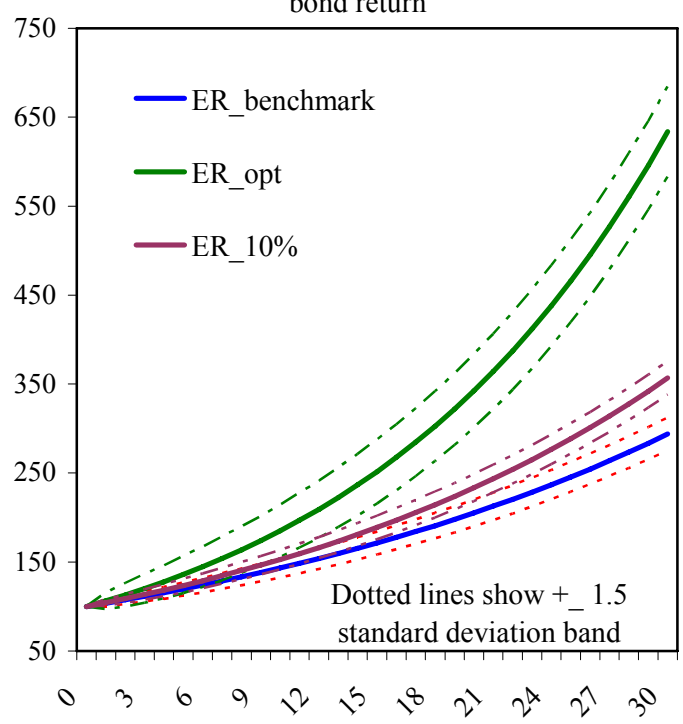

ER_bond $=3.66$, Stdev_bond $=2.24$, ER_Equity $=10.38$, Stdev_equity $=15.79$, Safe $r=3.66, \mathrm{~W}^{*}$ _equity $=40 \%$

Chart 4. Cumulative growth in Asset, higher

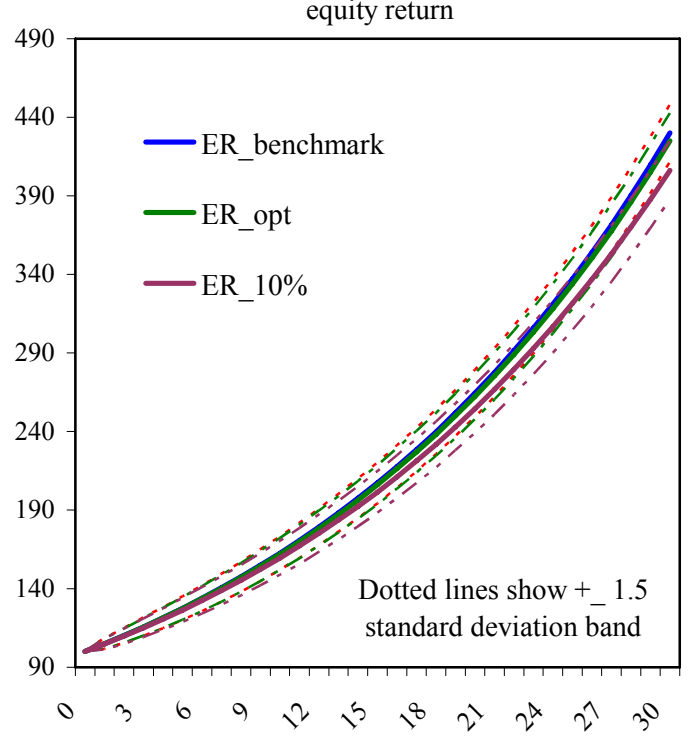

ER_bond $=4.98$, Stdev_bond $=2.24$, ER_Equity $=3.00$, Stdev_equity $=15.79, \overline{\text { Safe }} \mathrm{r}=3.66, \mathrm{~W}^{*}$ _equity $=2 \%$ equity volatility

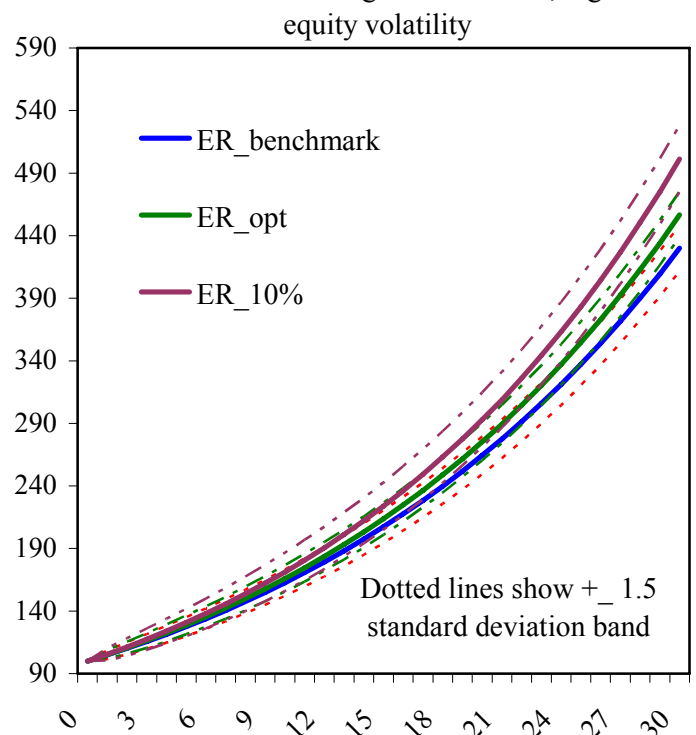

ER_bond $=4.98$, Stdev_bond $=2.24$, ER_Equity $=10.38$, Stdev_equity $=30.00$, Safe $r=3.66, \mathrm{~W}^{*}$ _equity $=4 \%$

Note: ER_benchmak means expected return for bond only portfolio, ER_opt shows expected return with optimal portfolio for a given set of parameters, and ER_10\% shows expected return from imposing $10 \%$ equity $90 \%$ bond allocation. 


\section{References}

Best, M. and R. Grauer, 1991, "On the Sensitivity of Mean-Variance-Efficient Portfolios to Changes in Asset Means: Some Analytical and Computational Results," The Review of Financial Studies, Vol. 4, No. 2, pp. 315-342.

Black, F. and R. Litterman, 1992, “Global Portfolio Optimization,” Financial Analysts Journal, Sep/Oct 1992, 48, 5.

Campbell, J. and L. Viceira, 2001, Strategic Asset Allocation: Portfolio Choice for LongTerm Investors.

Cassard, M. and David Folkerts-Landau (eds.), 2000, Sovereign Assets and Liabilities Management, International monetary Fund and The Hong Kong Monetary Authority.

Cuthbertson, K. and D. Nitzsche, 2004, Quantitative Financial Economics, John Wiley \& Sons, Ltd.

Fasano, U., 2000, "Review of the Experience with Oil Stabilization and Savings Funds in Selected Countries," IMF Working Paper No. 00/112 (Washington, D.C.: International Monetary Fund).

Norges Bank Investment Management, various years, Annual Report for the Government Petroleum Fund.

Ralf, J., 2002, Why move to bonds, The Actuary magazine, UK (March). 
Table 1. Timor-Leste: Selected Social Indicators, 2005 1/

\begin{tabular}{|c|c|c|c|c|c|c|}
\hline & $\begin{array}{c}\text { Timor- } \\
\text { Leste }\end{array}$ & & $\begin{array}{r}\text { East Asia } \\
\text { and Pacific } \\
\text { countries }\end{array}$ & & $\begin{array}{r}\text { Low } \\
\text { income } \\
\text { countries }\end{array}$ & \\
\hline Gross national per capita income (U.S. dollars) & 723 & & 1,627 & & 580 & \\
\hline GDP per capita income (U.S. dollars) & 366 & & $\ldots$ & & $\ldots$ & \\
\hline Area (in thousands of square kilometers) & 15 & & $\ldots$ & & $\cdots$ & \\
\hline \multicolumn{7}{|l|}{ Demography } \\
\hline Total population (in millions) & 1.0 & & 1,855 & & 2,353 & \\
\hline Population growth (in percent) & 3.7 & $2 /$ & 0.9 & & 1.9 & \\
\hline \multicolumn{7}{|l|}{ Life expectancy and mortality } \\
\hline Life expectancy at birth (years) & 56 & & 70 & & 59 & \\
\hline Male & 55 & & 68 & & 57 & \\
\hline Female & 57 & & 71 & & 59 & \\
\hline Infant mortality (per thousand live births) & 64 & $3 /$ & 29 & & 80 & \\
\hline Under 5 mortality rate (per thousand live births) & 80 & $3 /$ & 41 & & 123 & \\
\hline \multicolumn{7}{|l|}{ Education } \\
\hline Illiteracy rate (in percent) 4/ & 51 & & 91 & $5 /$ & 62 & $5 /$ \\
\hline Male & 46 & & $\ldots$ & & $\ldots$ & \\
\hline Female & 55 & & $\ldots$ & & $\ldots$ & \\
\hline Net primary school enrollment rate (in percent) & 75 & & 93 & $5 /$ & 77 & $5 /$ \\
\hline \multicolumn{7}{|l|}{$\begin{array}{l}\text { Immunization rate } \\
\text { (in percent of children aged } 12 \text { to } 23 \text { months) }\end{array}$} \\
\hline Measles & 55 & $3 /$ & 82 & & 65 & \\
\hline DPT & 70 & & 82 & & 67 & \\
\hline \multicolumn{7}{|l|}{ Other indicators $6 /$} \\
\hline Population below the poverty line & 40 & $5 /$ & $\ldots$ & & $\ldots$ & \\
\hline Households with access to electricity & 26 & & $\ldots$ & & $\ldots$ & \\
\hline Households with access to safe water & 58 & & 79 & & 75 & \\
\hline
\end{tabular}

Sources: UNDP Human Development Report 2006, World Bank, and Fund staff estimates.

1/ Unless otherwise indicated.

2/ World Bank 2005.

3/ Data for 2004. Provisional population count from 2004 census.

4/ For ages 15 and above.

5/ Figures are for 2001.

$6 /$ In percentage share of the total. 
Table 2. Timor-Leste: Selected Economic Indicators, 2001-06

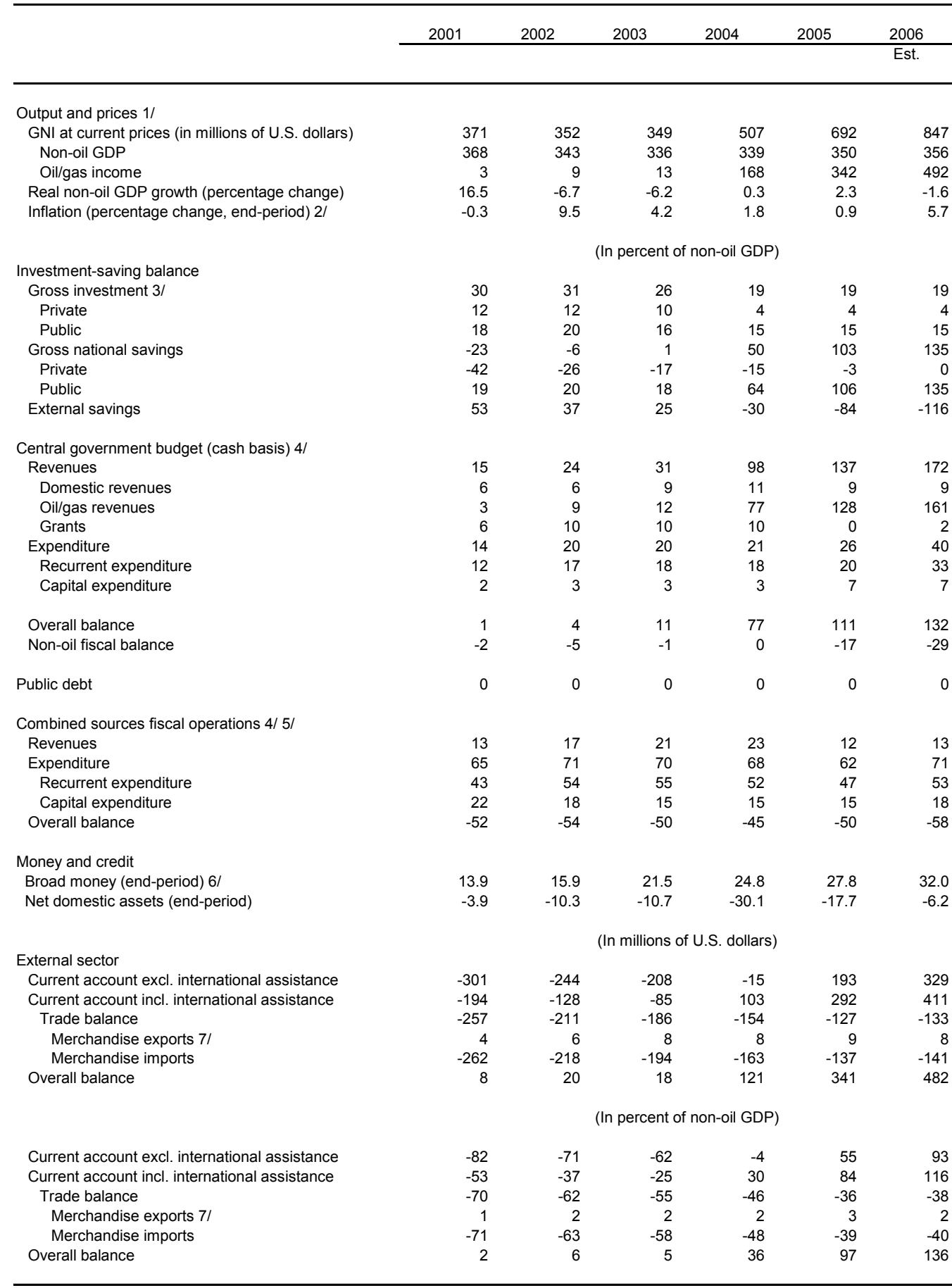

Sources: Data provided by the Timor-Leste authorities; and Fund staff estimates.

1/ Non-oil GDP and national accounts data for 2001-2003 are based on estimates prepared by a World Bank funded external consultant.

2/ CPI for Dili.

3/ Excludes oil/gas sector investment.

4/ Fiscal year basis (July-June); for example, 2001 refers to FY2001/02.

$5 /$ Includes autonomous agencies and fiscal and quasi-fiscal expenditure programs undertaken by bilaterals and multilaterals outside the central government budget. The sharp revenue decline in FY 2005/06 reflects the adoption of the new savings and petroleum fund policy according to which oil revenue accrue to the petroleum Fund and the sustainable income from the oil wealth is transferred to the budget to finance the non-oil fiscal deficit.

6/ Excludes currency holdings by the public, for which no data are available.

7/ Excludes oil/gas revenue, which are recorded under the income account (royalties) and transfers (tax revenues)

Also excludes re-exports, which primarily relate to repatriation of equipments from UN peacekeeping operations 
Table 3. Timor-Leste: Non-oil Gross Domestic Product by Sectoral Origin, 2000-06 1/

\begin{tabular}{|c|c|c|c|c|c|c|c|}
\hline & 2000 & 2001 & 2002 & 2003 & 2004 & 2005 & 2006 \\
\hline & & & & & & & Est. \\
\hline & \multicolumn{7}{|c|}{ At current market prices (in millions of U.S. dollars) } \\
\hline Agriculture, forestry, and fishery & 81.5 & 88.5 & 93.7 & 97.3 & 103.7 & 111.3 & 114.6 \\
\hline Food sector & 67.7 & 75.0 & 72.9 & 70.7 & 75.7 & 81.6 & 87.2 \\
\hline Commercial Agriculture, Forestry, Fisheries & 13.8 & 13.5 & 20.9 & 26.6 & 27.9 & 29.7 & 27.4 \\
\hline Industry and Services & 98.2 & 107.8 & 107.3 & 110.5 & 113.0 & 116.8 & 100.3 \\
\hline Mining \& quarrying (non-oil) & 3.8 & 3.8 & 3.2 & 2.6 & 2.7 & 2.9 & 2.0 \\
\hline Manufacturing & 8.7 & 10.9 & 11.0 & 11.4 & 11.6 & 11.8 & 9.1 \\
\hline Private construction & 15.8 & 16.2 & 15.1 & 14.4 & 14.5 & 15.0 & 11.3 \\
\hline Transport \& communications & 22.9 & 25.4 & 27.5 & 30.4 & 31.9 & 33.8 & 29.2 \\
\hline Wholesale \& retail trade & 24.6 & 25.6 & 23.9 & 24.2 & 24.5 & 24.9 & 23.4 \\
\hline Financial \& other services & 22.4 & 26.0 & 26.8 & 27.5 & 27.7 & 28.3 & 25.4 \\
\hline Public Sector & 136.6 & 171.7 & 142.3 & 127.9 & 122.0 & 121.8 & 140.8 \\
\hline Government services & 22.9 & 51.0 & 57.6 & 68.6 & 74.1 & 80.5 & 82.8 \\
\hline Public utilities & 2.7 & 1.4 & 2.7 & 3.5 & 4.1 & 5.0 & 4.4 \\
\hline Public construction & 27.6 & 27.9 & 21.8 & 15.6 & 14.5 & 18.4 & 18.6 \\
\hline United Nations 2/ & 83.4 & 91.4 & 60.2 & 40.2 & 29.3 & 18.0 & 35.1 \\
\hline \multirow[t]{2}{*}{ Total } & 316.3 & 367.9 & 343.3 & 335.7 & 338.6 & 349.9 & 355.7 \\
\hline & \multicolumn{7}{|c|}{ At constant 2000 market prices (in millions of U.S. dollars) } \\
\hline Agriculture, forestry, and fishery & 81.5 & 88.6 & 93.9 & 93.5 & 99.1 & 105.3 & 105.3 \\
\hline Food sector & 67.7 & 75.1 & 73.0 & 67.9 & 72.4 & 77.2 & 80.1 \\
\hline Commercial Agriculture, Forestry, Fisheries & 13.8 & 13.5 & 20.9 & 25.6 & 26.7 & 28.1 & 25.2 \\
\hline Industry and Services & 98.2 & 107.9 & 107.5 & 106.2 & 108.0 & 110.5 & 92.2 \\
\hline Mining \& quarrying (non-oil) & 3.8 & 3.8 & 3.2 & 2.5 & 2.6 & 2.7 & 1.8 \\
\hline Manufacturing & 8.7 & 10.9 & 11.0 & 11.0 & 11.1 & 11.2 & 8.4 \\
\hline Private construction & 15.8 & 16.2 & 15.1 & 13.8 & 13.9 & 14.2 & 10.4 \\
\hline Transport \& communications & 22.9 & 25.4 & 27.5 & 29.2 & 30.5 & 32.0 & 26.8 \\
\hline Wholesale \& retail trade & 24.6 & 25.6 & 23.9 & 23.3 & 23.4 & 23.6 & 21.5 \\
\hline Financial \& other services & 22.4 & 26.0 & 26.8 & 26.4 & 26.5 & 26.8 & 23.3 \\
\hline Public Sector & 136.6 & 171.9 & 142.5 & 122.9 & 116.6 & 115.3 & 128.3 \\
\hline Government services & 22.9 & 51.1 & 57.7 & 65.9 & 70.8 & 76.2 & 74.3 \\
\hline Public utilities & 2.7 & 1.4 & 2.7 & 3.4 & 3.9 & 4.7 & 4.5 \\
\hline Public construction & 27.6 & 27.9 & 21.8 & 15.0 & 13.9 & 17.4 & 16.9 \\
\hline United Nations 2/ & 83.4 & 91.5 & 60.3 & 38.6 & 28.0 & 17.0 & 32.5 \\
\hline Total & 316.3 & 368.4 & 343.9 & 322.6 & 323.7 & 331.1 & 325.8 \\
\hline
\end{tabular}

Sources: Data provided by the Timor Leste authorities; and Fund staff estimates.

1/ Data on oil and gas value added are not available. Figures for 2000-2003 are estimates made by BIDE consultants under a World Bank-supported technical assistance project.

$2 /$ Includes the value-added of services provided by UNTAET/UNMISET and donor-supported agencies acting on behalf of the Timor-Leste government. 
Table 4. Timor-Leste: Non-oil Gross Domestic Product by Expenditure, 2000-06 1/

\begin{tabular}{|c|c|c|c|c|c|c|c|}
\hline & 2000 & 2001 & 2002 & 2003 & 2004 & 2005 & 2006 \\
\hline & \multicolumn{6}{|c|}{ Estimates } & Est. \\
\hline & \multicolumn{7}{|c|}{ (In millions of U.S. dollars) } \\
\hline Non-oil GDP at current prices & 316.3 & 367.9 & 343.3 & 335.7 & 338.6 & 349.9 & 355.7 \\
\hline Consumption & 464.5 & 513.8 & 446.5 & 433.7 & 428.3 & 410.4 & 421.6 \\
\hline Private & 353.1 & 367.2 & 278.6 & 249.3 & 244.9 & 238.3 & 243.5 \\
\hline Government & 111.3 & 146.6 & 167.9 & 184.4 & 183.4 & 172.1 & 178.2 \\
\hline Investment & 80.9 & 111.3 & 108.0 & 88.2 & 64.7 & 67.0 & 67.6 \\
\hline Gross fixed capital formation & 69.0 & 96.8 & 96.1 & 77.7 & 58.7 & 60.2 & 60.8 \\
\hline Public Sector & 44.7 & 66.6 & 68.5 & 54.7 & 51.2 & 52.7 & 53.3 \\
\hline Private & 24.3 & 30.2 & 27.6 & 23.0 & 7.5 & 7.5 & 7.5 \\
\hline Changes in inventories & 11.9 & 14.5 & 11.9 & 10.5 & 6.0 & 6.8 & 6.8 \\
\hline Net Trade & -229.1 & -257.2 & -211.2 & -186.2 & -154.4 & -127.5 & -133.4 \\
\hline Exports & 1.3 & 4.3 & 6.4 & 7.8 & 8.3 & 9.2 & 7.9 \\
\hline Imports & -230.4 & -261.5 & -217.6 & -194.0 & -162.7 & -136.6 & -141.3 \\
\hline GNI at current prices & 320.7 & 371.0 & 352.2 & 348.8 & 506.5 & 692.3 & 847.4 \\
\hline GDP (non-oil) & 316.3 & 367.9 & 343.3 & 335.7 & 338.6 & 349.9 & 355.7 \\
\hline Oil income & 4.4 & 3.1 & 8.9 & 13.1 & 167.9 & 342.4 & 491.6 \\
\hline Gross national savings & -109.6 & -83.0 & -19.9 & 3.0 & 167.7 & 359.3 & 478.8 \\
\hline Private & -122.3 & -153.4 & -88.4 & -56.3 & -50.5 & -11.8 & -1.6 \\
\hline Public 2/ & 12.7 & 70.4 & 68.5 & 59.3 & 218.1 & 371.1 & 480.4 \\
\hline \multirow[t]{2}{*}{ External savings } & 190.5 & 194.3 & 127.9 & 85.2 & -102.9 & -292.3 & -411.2 \\
\hline & \multicolumn{7}{|c|}{ (In percent of non-oil GDP) } \\
\hline GDP at current prices & 100.0 & 100.0 & 100.0 & 100.0 & 100.0 & 100.0 & 100.0 \\
\hline Consumption & 146.8 & 139.7 & 130.1 & 129.2 & 126.5 & 117.3 & 118.5 \\
\hline Private & 111.6 & 99.8 & 81.2 & 74.3 & 72.3 & 68.1 & 68.4 \\
\hline Public 2/3/ & 35.2 & 39.9 & 48.9 & 54.9 & 54.2 & 49.2 & 50.1 \\
\hline Gross investment & 25.6 & 30.2 & 31.5 & 26.3 & 19.1 & 19.1 & 19.0 \\
\hline Private & 11.4 & 12.2 & 11.5 & 10.0 & 4.0 & 4.1 & 4.0 \\
\hline Public 2/ & 14.1 & 18.1 & 19.9 & 16.3 & 15.1 & 15.1 & 15.0 \\
\hline Exports & 0.4 & 1.2 & 1.9 & 2.3 & 2.5 & 2.6 & 2.2 \\
\hline Imports & -72.8 & -71.1 & -63.4 & -57.8 & -48.1 & -39.1 & -39.7 \\
\hline GNI at current prices & 101.4 & 100.8 & 102.6 & 103.9 & 149.6 & 197.8 & 238.2 \\
\hline non-oil GDP & 100.0 & 100.0 & 100.0 & 100.0 & 100.0 & 100.0 & 100.0 \\
\hline Oil income & 1.4 & 0.8 & 2.6 & 3.9 & 49.6 & 97.8 & 138.2 \\
\hline Gross national savings & -34.7 & -22.6 & -5.8 & 0.9 & 49.5 & 102.7 & 134.6 \\
\hline Private & -38.7 & -41.7 & -25.7 & -16.8 & -14.9 & -3.4 & -0.4 \\
\hline Public 2/ & 4.0 & 19.1 & 20.0 & 17.7 & 64.4 & 106.1 & 135.0 \\
\hline External savings & 60.2 & 52.8 & 37.2 & 25.4 & -30.4 & -83.5 & -115.6 \\
\hline
\end{tabular}

Sources: Data provided by the Timor-Leste authorities; and Fund staff estimates.

1/ For 2000-2003 the estimates are partially based on provisional national account data prepared by BIDE under a World Bank grant. Data from 2004 are Fund staff estimates.

2/ Includes fiscal and quasi-fiscal activities undertaken by multinational institutions and bilateral donors. $3 /$ Does not necessarily correspond to recurrent expenditures shown in Table 16 due to differences in the coverage of data (particularly those relating to technical assistance). 


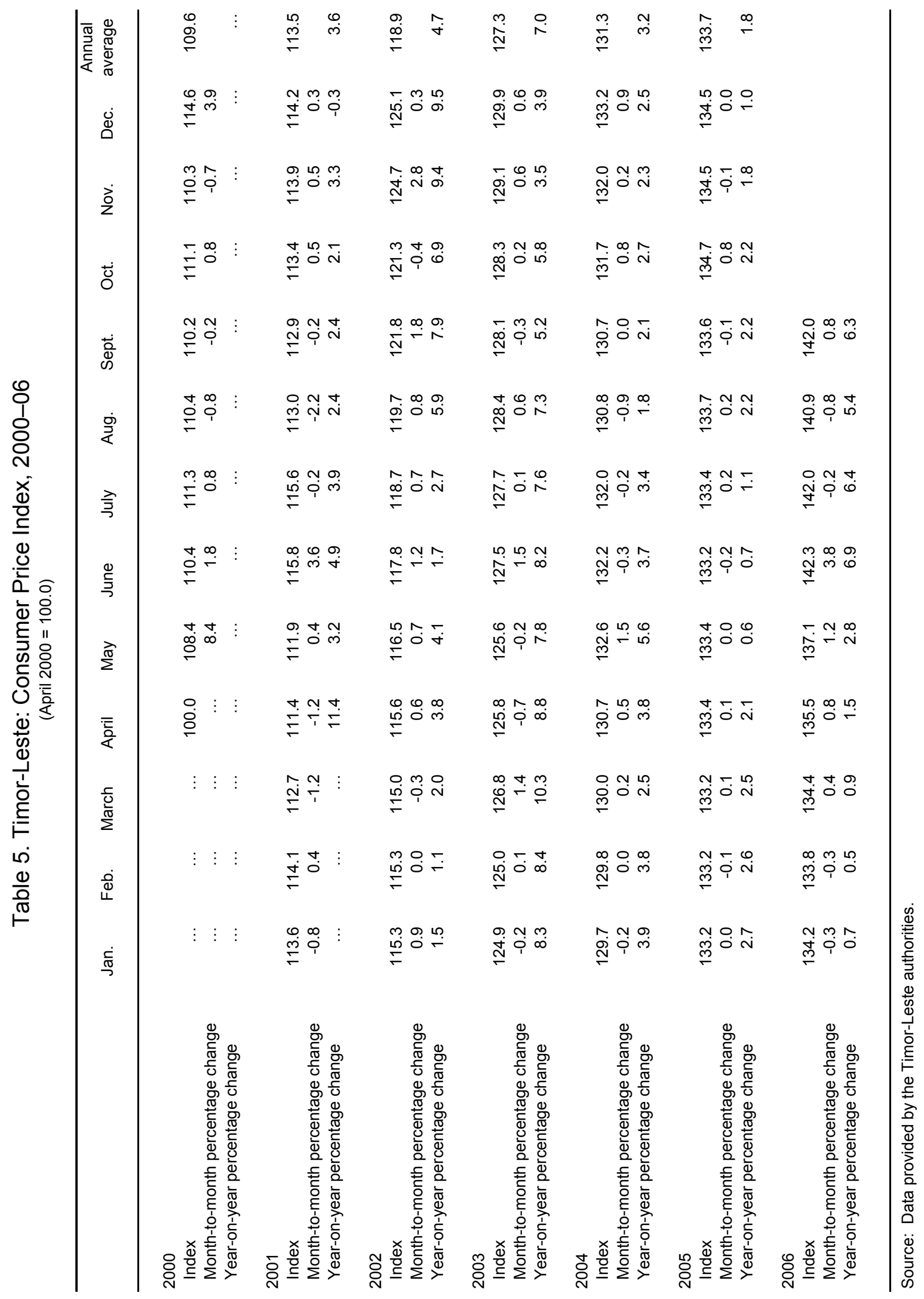




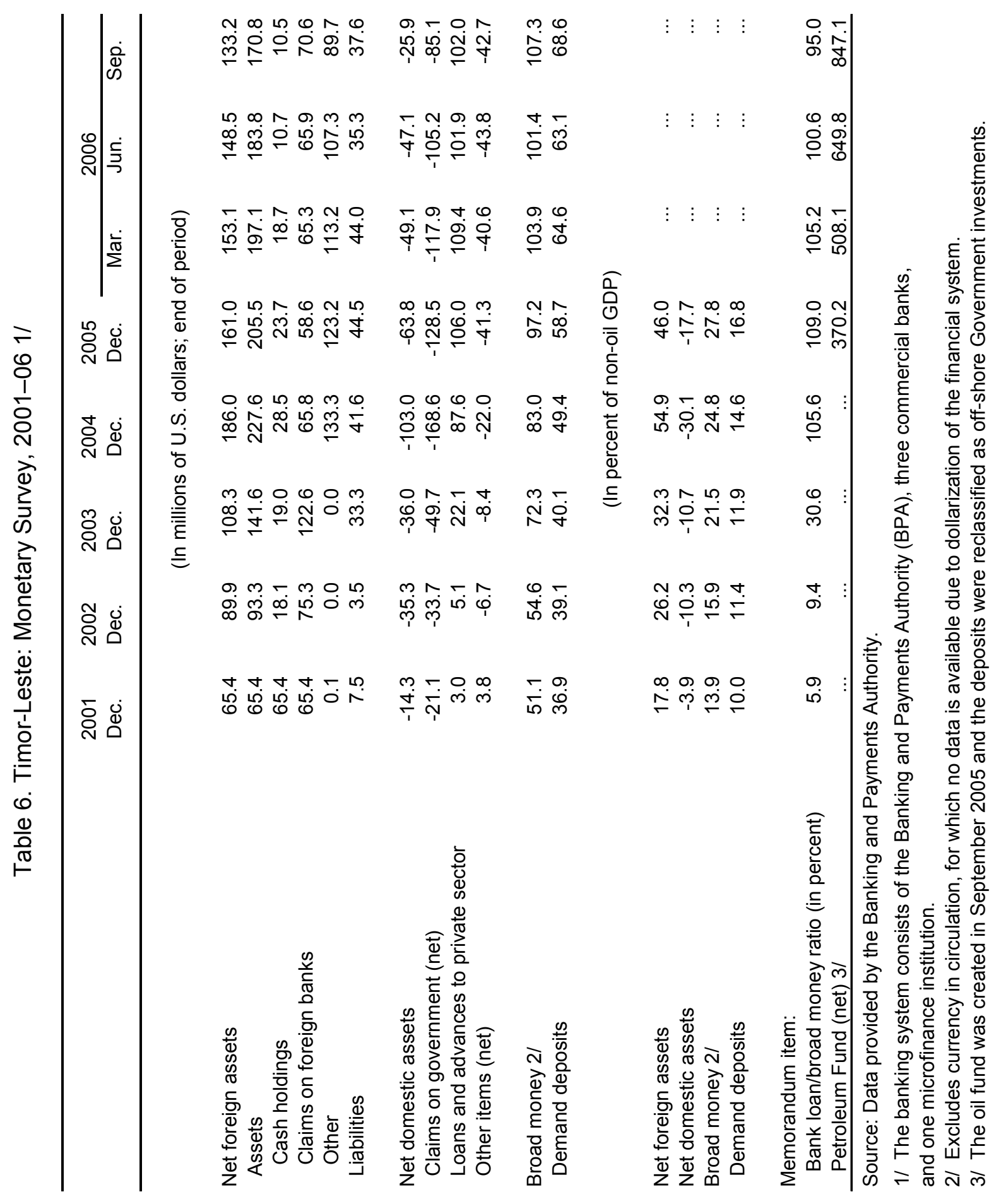




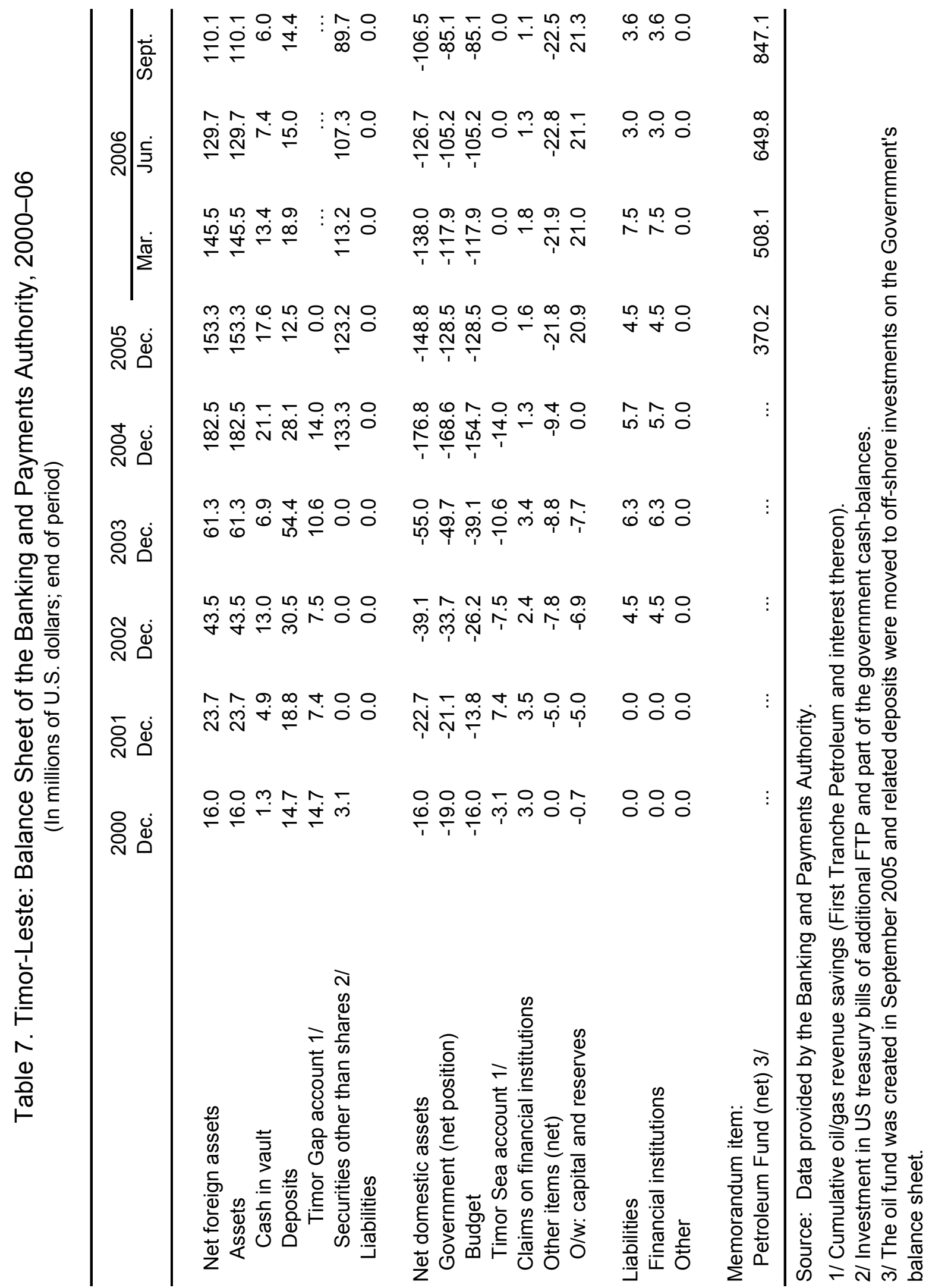




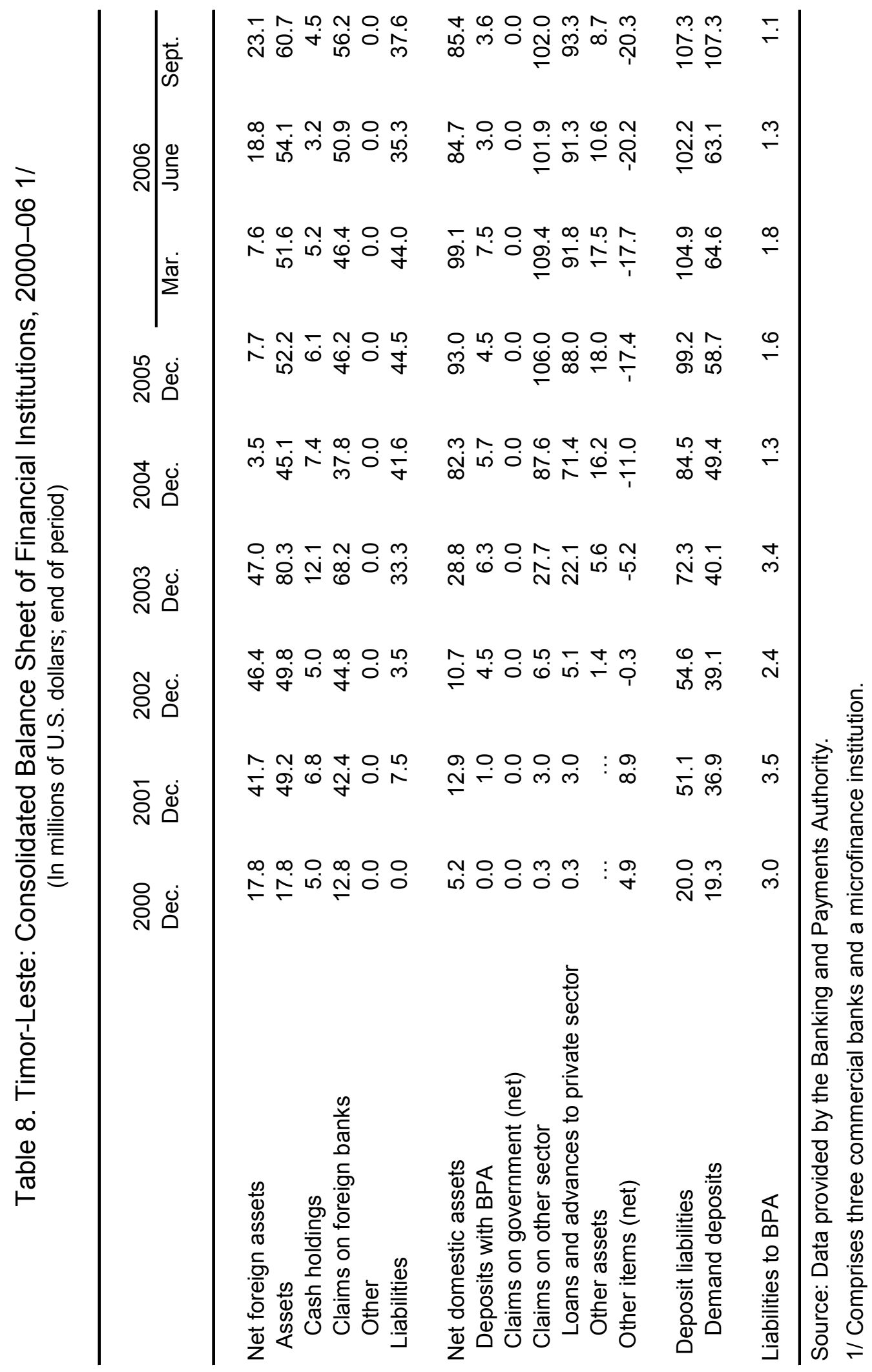


Table 9. Timor-Leste: Central Government Budget Operations, Cash Basis, 2002/03- 2006/07 1/

\begin{tabular}{|c|c|c|c|c|c|c|}
\hline & \multirow[t]{2}{*}{$2002 / 03$} & \multirow{2}{*}{$2003 / 04$} & \multirow{2}{*}{$2004 / 05$} & \multicolumn{2}{|c|}{$2005 / 06$} & \multirow{2}{*}{$\frac{2006 / 07}{\text { Budget } 2 /}$} \\
\hline & & & & Budget 2/ & Est. & \\
\hline & \multicolumn{6}{|c|}{ (In millions of U.S. dollars) } \\
\hline Revenue & 81.3 & 105.4 & 336.7 & 394.5 & 485.0 & 732.9 \\
\hline Domestic revenues & 19.3 & 29.2 & 36.9 & 33.6 & 33.4 & 39.1 \\
\hline Direct taxes & 5.3 & 6.6 & 10.7 & $\ldots$ & 8.5 & 7.9 \\
\hline Indirect taxes & 11.7 & 18.1 & 19.0 & $\ldots$ & 15.9 & 21.4 \\
\hline Non-tax revenues and other & 2.3 & 4.5 & 7.1 & 7.7 & 9.1 & 9.8 \\
\hline Oil/gas revenues & 29.5 & 41.4 & 265.6 & 350.9 & 451.3 & 683.5 \\
\hline Tax revenues & 26.4 & 38.0 & 209.4 & 266.0 & 362.8 & 557.9 \\
\hline Royalties and interest & 3.1 & 3.4 & 56.2 & 84.9 & 88.5 & 125.5 \\
\hline Royalties & 3.0 & 3.3 & 55.6 & 69.9 & 75.4 & 85.6 \\
\hline Interest & 0.1 & 0.1 & 0.6 & 15.0 & 13.1 & 40.0 \\
\hline Grants & 32.5 & 34.8 & 34.2 & 10 & 0 & 10 \\
\hline Expenditure & 68.5 & 68.4 & 71.4 & 132.0 & 93.0 & 309.2 \\
\hline Recurrent expenditure & 53.3 & 53.1 & 56.4 & 87.7 & 66.3 & 172.2 \\
\hline Wages and salaries & 21.6 & 23.8 & 25.1 & 28.8 & 25.7 & 47.4 \\
\hline Goods and services & 25.3 & 22.8 & 26.0 & 52.3 & 33.0 & 93.6 \\
\hline Transfers & 0.0 & 0.0 & 0.0 & 0.0 & 0.0 & 18.2 \\
\hline Subsidies to agencies & 6.4 & 6.6 & 5.3 & 6.6 & 7.5 & 12.9 \\
\hline Capital expenditure & 4.7 & 2.4 & 2.8 & 44.3 & 15.7 & 137.0 \\
\hline Previous year spending & 10.5 & 13.0 & 12.2 & 0.0 & 11.0 & 0.0 \\
\hline Overall balance & 12.8 & 37.0 & 265.3 & 262.5 & 392.1 & 423.7 \\
\hline Financing & -12.8 & -37.0 & -265.3 & -262.5 & -392.1 & -423.7 \\
\hline Changes in CFET cash balances (increase -) & -8.6 & -29.8 & -28.8 & -26.8 & -25.8 & -23.8 \\
\hline Oil/gas revenue savings (increase -) 3/ & -3.1 & -3.4 & -56.2 & -84.9 & -88.5 & -125.5 \\
\hline \multirow[t]{2}{*}{ Other } & -1.1 & -3.8 & -180.3 & -150.8 & -277.8 & -274.3 \\
\hline & \multicolumn{6}{|c|}{ (In percent of non-oil GDP) } \\
\hline Revenue & 23.9 & 31.3 & 97.8 & 111.8 & 137.5 & 172.6 \\
\hline Domestic revenues & 5.7 & 8.7 & 10.7 & 9.5 & 9.5 & 9.2 \\
\hline Direct taxes & 1.5 & 2.0 & 3.1 & $\ldots$ & 2.4 & 1.9 \\
\hline Indirect taxes & 3.5 & 5.4 & 5.5 & $\ldots$ & 4.5 & 5.0 \\
\hline Non-tax revenues and other & 0.7 & 1.3 & 2.1 & 2.2 & 2.6 & 2.3 \\
\hline Oil/gas revenues & 8.7 & 12.3 & 77.1 & 99.5 & 127.9 & 161.0 \\
\hline Of which: Tax revenues & 7.8 & 11.3 & 60.8 & 75.4 & 102.8 & 131.4 \\
\hline Expenditure & 20.2 & 20.3 & 20.7 & 37.4 & 26.3 & 72.8 \\
\hline Recurrent expenditure & 15.7 & 15.8 & 16.4 & 24.9 & 18.8 & 40.6 \\
\hline Wages and salaries & 6.4 & 7.0 & 7.3 & 8.2 & 7.3 & 11.2 \\
\hline Goods and services & 7.5 & 6.8 & 7.5 & 14.8 & 9.4 & 22.0 \\
\hline Capital expenditure & 1.4 & 0.7 & 0.8 & 12.6 & 4.4 & 32.3 \\
\hline Overall balance & 3.8 & 11.0 & 77.1 & 74.4 & 111.1 & 99.8 \\
\hline \multirow[t]{2}{*}{ Financing } & -3.8 & -11.0 & -77.1 & -74.4 & -111.1 & -99.8 \\
\hline & \multicolumn{6}{|c|}{ (In millions of U.S. dollars unless otherwise indicated) } \\
\hline \multicolumn{7}{|l|}{ Memorandum items: } \\
\hline Cumulative oil/gas savings (end-period) & 10.5 & 13.9 & 70.1 & 374.0 & 650 & 1,047 \\
\hline (In percent of GDP) & 3.1 & 4.1 & 20.4 & 106.0 & 184.1 & 246.6 \\
\hline (In percent of recurrent expenditure) & 19.8 & 26.2 & 124.3 & 426.5 & 980.3 & 608.2 \\
\hline Non-oil overall fiscal balance & -16.7 & -4.4 & -0.3 & -88.4 & -59.2 & -259.8 \\
\hline (In percent of non-oil GDP) & -4.9 & -1.3 & -0.1 & -25.1 & -16.8 & -61.2 \\
\hline
\end{tabular}

Sources: Data provided by the Timor-Leste authorities; and Fund staff estimates.

1/ Fiscal year: July-June. Expenditure actuals are reported on a cash basis.

2/ Budgets are appropriated on a commitment basis.

3/ Under the current oil/gas saving policy, royalties and interest income are automatically saved and only tax revenues are available for budget financing. 
Table 10. Timor-Leste: Central Government Domestic Non-oil Revenues, 2001/02- 2006/07 $1 /$

\begin{tabular}{|c|c|c|c|c|c|c|c|}
\hline & \multirow[t]{2}{*}{$2001 / 02$} & \multirow[t]{2}{*}{$2002 / 03$} & \multirow[t]{2}{*}{ 2003/04 } & \multirow[t]{2}{*}{ 2004/05 } & \multicolumn{2}{|c|}{$2005 / 06$} & \multirow{2}{*}{$\frac{2006 / 07}{\text { Budget }}$} \\
\hline & & & & & Budget & Est. & \\
\hline & \multicolumn{7}{|c|}{ (In millions of U.S. dollars) } \\
\hline Total domestic non-oil revenue & 20.5 & 19.3 & 29.2 & 36.9 & 33.6 & 33.4 & 39.1 \\
\hline Tax revenue & 18.1 & 17.0 & 24.8 & 29.7 & 25.9 & 24.4 & 29.3 \\
\hline Direct tax & 5.4 & 5.3 & 6.6 & 10.7 & $\ldots$ & 8.5 & 7.9 \\
\hline Wage tax & 2.5 & 2.7 & 2.9 & 3.3 & $\ldots$ & 2.8 & 3.9 \\
\hline Government & 0.5 & 0.5 & 0.6 & 0.6 & $\ldots$ & 0.6 & 0.0 \\
\hline Other & 1.9 & 2.2 & 2.3 & 2.7 & $\ldots$ & 2.1 & 0.0 \\
\hline Corporate income tax & 1.7 & 1.7 & 1.8 & 4.3 & $\ldots$ & 4.6 & 4.0 \\
\hline Special withholding tax & 1.3 & 0.9 & 1.9 & 3.1 & $\ldots$ & 1.2 & 0.0 \\
\hline Indirect tax & 12.7 & 11.7 & 18.1 & 19.0 & $\ldots$ & 15.9 & 21.4 \\
\hline Tax on goods and services & 9.6 & 8.7 & 14.2 & 15.0 & $\ldots$ & 12.5 & 16.9 \\
\hline Sales tax $3 /$ & 3.3 & 3.4 & 4.3 & 4.4 & $\ldots$ & 3.4 & 4.3 \\
\hline Excise duty $3 /$ & 4.3 & 3.4 & 7.2 & 8.1 & $\ldots$ & 7.0 & 8.3 \\
\hline Service tax 4/ & 2.0 & 1.9 & 2.6 & 2.4 & $\ldots$ & 2.1 & 4.3 \\
\hline Tax on international trade & 3.1 & 3.0 & 3.9 & 4.1 & $\ldots$ & 3.3 & 4.5 \\
\hline Import duty & 3.1 & 3.0 & 3.9 & 4.1 & $\ldots$ & 3.3 & 4.5 \\
\hline Export duty $5 /$ & 0.0 & 0.0 & 0.0 & 0.0 & $\ldots$ & 0.0 & 0.0 \\
\hline Non-tax revenue & 2.4 & 2.3 & 4.5 & 7.1 & 7.7 & 9.1 & 9.8 \\
\hline Fees and charges & 1.8 & 2.1 & 4.1 & 4.3 & 5.2 & 3.8 & 6.4 \\
\hline O/w: Property rental & 1.1 & 1.1 & 1.3 & 1.5 & $\ldots$ & n.a. & 1.9 \\
\hline \multirow[t]{2}{*}{ Interest receipts and other } & 0.6 & 0.2 & 0.4 & 2.8 & 2.5 & 5.2 & 3.4 \\
\hline & \multicolumn{7}{|c|}{ (In percent of non-oil GDP) } \\
\hline Total domestic non-oil revenue & 5.8 & 5.7 & 8.7 & 10.7 & 9.5 & 9.5 & 9.2 \\
\hline Tax revenue & 5.1 & 5.0 & 7.3 & 8.6 & 7.3 & 6.9 & 6.9 \\
\hline Direct tax & 1.5 & 1.5 & 2.0 & 3.1 & $\ldots$ & 2.4 & 1.9 \\
\hline Wage tax & 0.7 & 0.8 & 0.9 & 1.0 & $\ldots$ & 0.8 & 0.9 \\
\hline Corporate income tax & 0.5 & 0.5 & 0.5 & 1.2 & $\ldots$ & 1.3 & 0.9 \\
\hline Special withholding tax & 0.4 & 0.3 & 0.6 & 0.9 & $\ldots$ & 0.3 & 0.0 \\
\hline Indirect tax & 3.6 & 3.5 & 5.4 & 5.5 & $\ldots$ & 4.5 & 5.0 \\
\hline Tax on goods and services & 2.7 & 2.6 & 4.2 & 4.3 & $\ldots$ & 3.6 & 4.0 \\
\hline Sales tax $3 /$ & 0.9 & 1.0 & 1.3 & 1.3 & $\ldots$ & 1.0 & 1.0 \\
\hline Excise duty $3 /$ & 1.2 & 1.0 & 2.1 & 2.4 & $\ldots$ & 2.0 & 2.0 \\
\hline Service tax 4/ & 0.6 & 0.6 & 0.8 & 0.7 & $\ldots$ & 0.6 & 1.0 \\
\hline Tax on international trade & 0.9 & 0.9 & 1.2 & 1.2 & $\ldots$ & 0.9 & 1.1 \\
\hline Non-tax revenue & 0.7 & 0.7 & 1.3 & 2.1 & 2.2 & 2.6 & 2.3 \\
\hline \multicolumn{8}{|l|}{ Memorandum item: } \\
\hline Taxes collected at the border (US dollar millions) & 10.7 & 9.8 & 15.5 & 16.6 & $\ldots$ & 13.8 & 17.1 \\
\hline (In percent of non-oil GDP) & 3.0 & 2.9 & 4.6 & 4.8 & $\ldots$ & 3.9 & 4.0 \\
\hline
\end{tabular}

Sources: Data provided by the Timor-Leste authorities and Fund staff calculations.

1/ Fiscal year: July-June.

2/ Supplementary budget adopted in February 2005.

$3 /$ Currently collected only at the border.

4/ Turnover tax on hotel, restaurant, and transportation rental services.

5/ Abolished in July 2001. 
Table 11. Timor-Leste: Oil/gas Revenues, 2000/01-2006/07 1/

\begin{tabular}{|c|c|c|c|c|c|c|c|}
\hline & $2000 / 01$ & $2001 / 02$ & $2002 / 03$ & $2003 / 04$ & $2004 / 05$ & $2005 / 06$ & $\begin{array}{r}2006 / 07 \\
\text { Budget }\end{array}$ \\
\hline & \multicolumn{7}{|c|}{ (In millions of U.S. dollars) } \\
\hline Total oil/gas revenues & 13.1 & 10.8 & 29.5 & 41.4 & 265.6 & 451.3 & 683.5 \\
\hline Tax revenues & 9.9 & 6.5 & 26.4 & 38.0 & 209.4 & 362.8 & 557.9 \\
\hline Income tax & 6.8 & 4.7 & 15.5 & 25.9 & 209.4 & 336.0 & 541.3 \\
\hline VAT & 3.1 & 1.7 & 10.9 & 12.1 & 0.0 & 4.4 & 3.4 \\
\hline Other & & & & & 0.0 & 22.4 & 13.2 \\
\hline Royalties and interest & 3.1 & 4.3 & 3.1 & 3.4 & 56.2 & 88.5 & 125.5 \\
\hline Royalties & 3.0 & 4.2 & 3.0 & 3.3 & 55.6 & 75.4 & 85.6 \\
\hline \multirow[t]{2}{*}{ Interest income } & 0.1 & 0.1 & 0.1 & 0.1 & 0.6 & 13.1 & 40.0 \\
\hline & \multicolumn{7}{|c|}{ (In percent of non-oil GDP) } \\
\hline Total oil/gas revenues & 3.8 & 3.0 & 8.7 & 12.3 & 77.1 & 127.9 & 161.0 \\
\hline Tax revenues & 2.9 & 1.8 & 7.8 & 11.3 & 60.8 & 102.8 & 131.4 \\
\hline Income tax & 2.0 & 1.3 & 4.6 & 7.7 & 60.8 & 95.2 & 127.5 \\
\hline VAT & 0.9 & 0.5 & 3.2 & 3.6 & 0.0 & 1.2 & 0.8 \\
\hline Other & 0.0 & 0.0 & 0.0 & 0.0 & 0.0 & 6.4 & 3.1 \\
\hline Royalties and interest & 0.9 & 1.2 & 0.9 & 1.0 & 16.3 & 25.1 & 29.6 \\
\hline Royalties & 0.9 & 1.2 & 0.9 & 1.0 & 16.2 & 21.4 & 20.2 \\
\hline Interest income & 0.0 & 0.0 & 0.0 & 0.0 & 0.2 & 3.7 & 9.4 \\
\hline \multicolumn{8}{|l|}{ Memorandum items: } \\
\hline Cumulative oil/gas savings (end-period) & 3.1 & 7.4 & 10.5 & 13.9 & 14.9 & 649.7 & 1211.3 \\
\hline (In percent of GDP) & 0.9 & 2.1 & 3.1 & 4.1 & 4.3 & 184.1 & 285.3 \\
\hline
\end{tabular}

Sources: Data provided by the Timor-Leste authorities; and Fund staff estimates and calculations.

1/ Fiscal year: July-June. 
Table 12. Timor-Leste: General Government Expenditure Composition, 2001/02 - 2004/05 1/

\begin{tabular}{|c|c|c|c|c|}
\hline & $2001 / 02$ & $2002 / 03$ & $2003 / 04$ & $2004 / 05$ \\
\hline & \multicolumn{4}{|c|}{ (In millions of U.S. dollars) } \\
\hline Total expenditure (cash basis) & 51.4 & 70.1 & 70.3 & 77.7 \\
\hline Wages and salaries & 18.9 & 22.1 & 24.2 & 25.6 \\
\hline Salaries & 18.9 & 22.1 & 24.2 & 25.6 \\
\hline Overtime/allowances & n.a. & n.a. & n.a. & n.a. \\
\hline Goods and services & 20.9 & 32.2 & 32.0 & 37.0 \\
\hline Travel & 0.8 & 1.7 & 1.7 & 1.9 \\
\hline Training/workshops & 0.3 & 0.7 & 0.5 & 0.8 \\
\hline Utilities & 0.4 & 1.7 & 1.9 & 2.1 \\
\hline Fuel for generators & 5.7 & 7.8 & 7.9 & 9.2 \\
\hline Vehicle operation & 1.6 & 4.6 & 4.7 & 4.3 \\
\hline Current transfers to BPA & 0.6 & 0.2 & 0.2 & 0.6 \\
\hline Other operational expenses & 1.5 & 1.1 & 1.2 & 1.5 \\
\hline Others & 9.9 & 14.4 & 13.8 & 15.3 \\
\hline Refund of Revenue & 0.0 & 0.0 & 0.0 & 1.4 \\
\hline Capital expenditure & 5.1 & 5.3 & 2.6 & 3.3 \\
\hline Infrastructure investment & 2.3 & 2.4 & 0.9 & 1.7 \\
\hline Purchase of equipment & 2.2 & 2.4 & 1.3 & 1.1 \\
\hline Other & 0.6 & 0.5 & 0.4 & 0.4 \\
\hline \multirow[t]{2}{*}{ Payments carried over from previous years } & 6.5 & 10.5 & 11.4 & 11.9 \\
\hline & \multicolumn{4}{|c|}{ (In percent of non-oil GDP) } \\
\hline Total expenditure (cash basis) & 14.4 & 20.7 & 20.8 & 22.6 \\
\hline Wages and salaries & 5.3 & 6.5 & 7.2 & 7.4 \\
\hline Goods and services & 5.9 & 9.5 & 9.5 & 10.8 \\
\hline Capital expenditure & 1.4 & 1.6 & 0.8 & 1.0 \\
\hline Carry-over expenditures & 1.8 & 3.1 & 3.4 & 3.4 \\
\hline
\end{tabular}

Sources: Data provided by the Timor-Leste Authorities.

1/ Fiscal year: July-June. Financial statement includes transactions of central government (table 9) Aviation, Port and Power accounts. 
Table 13. Timor-Leste: Public Sector Employment and Wages, 2002/03- 2005/06

(In number of employees unless otherwise specified) $1 /$

\begin{tabular}{|c|c|c|c|c|c|c|c|c|c|}
\hline & & \multicolumn{2}{|c|}{$2002 / 03$} & \multicolumn{2}{|c|}{$2003 / 04$} & \multirow{2}{*}{$\begin{array}{r}2004 / 05 \\
\text { Budget }\end{array}$} & \multirow{2}{*}{$\frac{2005 / 06}{\text { Budget }}$} & \multirow{2}{*}{$\begin{array}{l}\text { 2006/07 } \\
\text { Budget }\end{array}$} & \multirow{2}{*}{$\begin{array}{c}\text { Monthly } \\
\text { wage 2/ 3/ }\end{array}$} \\
\hline & & Budget & Act. & Budget & Act. & & & & \\
\hline \multicolumn{2}{|c|}{ Total government employees 4/ } & 16,387 & 13,170 & 17,150 & 14,300 & 17,175 & 18,161 & 21,176 & \\
\hline \multicolumn{2}{|l|}{ L1 } & 3,440 & 2,601 & 2,696 & 1,385 & 1,518 & 1,306 & 1,584 & 85 \\
\hline \multicolumn{2}{|l|}{ L2 } & 2,024 & 2,018 & 3,228 & 3,472 & 4,180 & 4,348 & 4,657 & 110 \\
\hline \multicolumn{2}{|l|}{ L3 } & 6,793 & 5,187 & 6,698 & 5,862 & 6,825 & 7,265 & 8,850 & 123 \\
\hline \multirow{2}{*}{\multicolumn{2}{|c|}{$\begin{array}{l}\text { L4 } \\
\text { L5 }\end{array}$}} & 3,357 & 2,920 & 3,658 & 2,972 & 3,741 & 3,958 & 4,148 & 155 \\
\hline & & 549 & 320 & 622 & 454 & 666 & 903 & 1,379 & 201 \\
\hline \multicolumn{2}{|l|}{ L6 } & 201 & 112 & 225 & 128 & 223 & 314 & 458 & 266 \\
\hline \multicolumn{2}{|l|}{ L7 } & 23 & 12 & 23 & 27 & 22 & 67 & 100 & 361 \\
\hline \multicolumn{2}{|c|}{ Total non-police/defense 4/ } & 12,139 & 9,474 & 12,442 & 10,087 & 12,489 & 13,454 & 16,220 & \\
\hline \multicolumn{2}{|l|}{ L1 } & 839 & 562 & 669 & 304 & 667 & 730 & 1006 & 85 \\
\hline \multirow{2}{*}{\multicolumn{2}{|c|}{$\begin{array}{l}\text { L2 } \\
\text { L3 }\end{array}$}} & 970 & 688 & 1,074 & 794 & 1,105 & 1,231 & 1465 & 110 \\
\hline & & 6,380 & 5,164 & 6,516 & 5,680 & 6,483 & 6,728 & 8135 & 123 \\
\hline \multicolumn{2}{|l|}{ L4 } & 3,222 & 2,630 & 3,367 & 2,739 & 3,384 & 3,566 & 3761 & 155 \\
\hline \multicolumn{2}{|l|}{ L5 } & 513 & 309 & 584 & 418 & 611 & 828 & 1305 & 201 \\
\hline \multirow{2}{*}{\multicolumn{2}{|c|}{$\begin{array}{l}\text { L6 } \\
\text { L7 }\end{array}$}} & 194 & 110 & 213 & 126 & 219 & 307 & 451 & 266 \\
\hline & & 21 & 11 & 19 & 26 & 20 & 64 & 97 & 361 \\
\hline \multicolumn{2}{|c|}{ Police (PNTL) 5/ } & 2,855 & 2,581 & 3,362 & 3,033 & 3,251 & 3,251 & 3,503 & \\
\hline \multicolumn{2}{|l|}{ L1 } & 1,400 & 1,126 & 1,082 & 267 & 221 & 0 & 2 & 85 \\
\hline \multicolumn{2}{|l|}{ L2 } & 1,000 & 1,207 & 1,887 & 2,549 & 2,665 & 2793 & 2869 & 110 \\
\hline \multicolumn{2}{|l|}{ L3 } & 370 & 2 & 100 & 5 & 90 & 141 & 319 & 123 \\
\hline \multicolumn{2}{|l|}{ L4 } & 55 & 245 & 250 & 189 & 240 & 270 & 267 & 155 \\
\hline \multirow{2}{*}{\multicolumn{2}{|c|}{$\begin{array}{l}\text { L5 } \\
\text { L6 }\end{array}$}} & 24 & 0 & 30 & 22 & 31 & 43 & 42 & 201 \\
\hline & & 5 & 1 & 10 & 1 & 3 & 3 & 3 & 266 \\
\hline L7 & & 1 & 0 & 3 & 0 & 1 & 1 & 1 & 361 \\
\hline Defens & (FDTL) $5 /$ & 1,393 & 1,115 & 1,346 & 1,180 & 1,435 & 1,456 & 1,453 & \\
\hline L1 & Recruit/ DEF01-02 & 1,201 & 913 & 945 & 814 & 630 & 576 & 576 & 85 \\
\hline L2 & DEF03-05 & 54 & 123 & 267 & 129 & 410 & 324 & 323 & 110 \\
\hline L3 & DEF06-08 & 43 & 21 & 82 & 177 & 252 & 396 & 396 & 123 \\
\hline L4 & DEF09-10 & 80 & 45 & 41 & 44 & 117 & 122 & 120 & 155 \\
\hline L5 & DEF11-12 & 12 & 11 & 8 & 14 & 24 & 32 & 32 & 201 \\
\hline L6 & DEF13 & 2 & 1 & 2 & 1 & 1 & 4 & 4 & 266 \\
\hline L7 & DEF14 & 1 & 1 & 1 & 1 & 1 & 2 & 2 & 361 \\
\hline $\begin{array}{r}\text { Memor } \\
\text { Avere }\end{array}$ & $\begin{array}{l}\text { dum item: } \\
\text { monthly wage (in US\$ }\end{array}$ & & & & & & & & \\
\hline Tot & employee & 125 & 139 & 126 & 149 & 137 & 131 & 133 & $\ldots$ \\
\hline Tot & non-police/defense & 134 & 133 & 135 & $\ldots$ & 135 & 137 & 139 & $\ldots$ \\
\hline Poli & & 101 & 103 & 107 & $\ldots$ & 113 & 116 & 116 & $\ldots$ \\
\hline Def & & 93 & 93 & 96 & $\ldots$ & 107 & 110 & 110 & $\ldots$ \\
\hline
\end{tabular}

Sources: Data provided by the Timor-Leste authorities and Fund staff estimates and calculations.

$1 /$ Includes Permanent and Temporary staff. Excludes casual staff, which have been included in the 2006/07 budget documents. 2/ Figures relate to the average wage for permenant staff in each grade in U.S. dollars.

3/ The public sector pay-scale has not been changed since 2000/01. Excludes the Cost of Living Allowance awarded in $2006 / 07$. 4/ Includes Autonomous Agency staff, Judges, University Staff and other categories not classified as civil servants.

$5 /$ Taken from Ministry staffing records, which includes some administrative functions. 
55

Table 14. Timor-Leste: Autonomous Agencies Operations, 2002/03 - 2006/07 1/

\begin{tabular}{|c|c|c|c|c|c|}
\hline & $2002 / 03$ & $2003 / 04$ & $2004 / 05$ & $\begin{array}{c}2005 / 06 \\
\text { Est. }\end{array}$ & $\begin{array}{l}2006 / 07 \\
\text { Budget }\end{array}$ \\
\hline & \multicolumn{5}{|c|}{ (In millions of U.S. dollars) } \\
\hline Total retained revenues & 4.9 & 5.5 & 8.1 & 6.5 & 6.5 \\
\hline Aviation & 1.0 & 1.0 & 1.0 & 0.7 & 0.9 \\
\hline Port & 1.1 & 1.0 & 0.9 & 0.9 & 1.3 \\
\hline Power & 2.9 & 3.5 & 6.2 & 4.9 & 4.0 \\
\hline Other 21 & $\ldots$ & $\ldots$ & $\ldots$ & 0.0 & 0.3 \\
\hline Total expenditures & 12.6 & 10.6 & 13.2 & 11.5 & 24.9 \\
\hline Aviation & 0.8 & 0.6 & 0.9 & 0.5 & 1.9 \\
\hline Port & 0.5 & 0.3 & 0.9 & 0.2 & 4.4 \\
\hline Power & 11.2 & 9.7 & 11.4 & 10.8 & 18.5 \\
\hline Other & $\ldots$ & $\ldots$ & $\ldots$ & 0.3 & 1.2 \\
\hline Wages and salaries & 0.5 & 0.4 & 0.5 & 0.5 & 0.6 \\
\hline Aviation & 0.1 & 0.1 & 0.2 & 0.1 & 0.1 \\
\hline Port & 0.1 & 0.1 & 0.1 & 0.1 & 0.1 \\
\hline Power & 0.3 & 0.3 & 0.3 & 0.3 & 0.4 \\
\hline Other & $\ldots$ & $\ldots$ & $\cdots$ & 0.1 & 0.2 \\
\hline Goods and services & 9.5 & 10.0 & 11.8 & 10.8 & 17.2 \\
\hline Aviation & 0.5 & 0.5 & 0.6 & 0.3 & 0.6 \\
\hline Port & 0.2 & 0.2 & 0.3 & 0.1 & 0.5 \\
\hline Power & 8.8 & 9.3 & 10.9 & 10.5 & 16.2 \\
\hline Other & $\ldots$ & $\ldots$ & $\ldots$ & 0.2 & 0.9 \\
\hline Capital & 2.5 & 0.2 & 0.9 & 0.2 & 7.1 \\
\hline Aviation & 0.2 & 0.0 & 0.2 & 0.2 & 1.2 \\
\hline Port & 0.3 & 0.0 & 0.5 & 0.0 & 3.8 \\
\hline Power & 2.0 & 0.1 & 0.3 & 0.0 & 2.0 \\
\hline Other & $\ldots$ & $\ldots$ & $\ldots$ & 0.0 & 0.1 \\
\hline Overall balance & -7.7 & -5.1 & -5.1 & -5.1 & -18.4 \\
\hline Aviation & 0.2 & 0.4 & 0.1 & 0.2 & -1.1 \\
\hline Port & 0.5 & 0.7 & 0.0 & 0.7 & -3.1 \\
\hline Power & -8.3 & -6.2 & -5.2 & -5.9 & -14.5 \\
\hline Other & $\ldots$ & $\ldots$ & $\ldots$ & -0.3 & -0.9 \\
\hline Financing & 7.7 & 5.1 & 5.1 & 5.1 & 18.4 \\
\hline Transfers from the budget & 8.4 & 6.6 & 5.7 & 6.4 & 16.6 \\
\hline Aviation & 0.0 & 0.0 & 0.0 & 0.2 & 1.1 \\
\hline Port & 0.0 & 0.0 & 0.0 & 0.7 & 3.1 \\
\hline Power & 8.4 & 6.6 & 5.7 & 5.5 & 12.4 \\
\hline Other & $\ldots$ & $\ldots$ & $\ldots$ & -0.3 & 1.0 \\
\hline Other (Increase -) & -0.8 & -1.5 & -0.5 & -1.3 & 1.8 \\
\hline Aviation & -0.2 & -0.4 & -0.1 & -0.4 & 0.0 \\
\hline Port & -0.5 & -0.7 & 0.0 & -1.4 & 0.0 \\
\hline Power & -0.1 & -0.4 & -0.4 & 0.4 & 2.1 \\
\hline \multirow[t]{2}{*}{ Other } & $\ldots$ & $\cdots$ & $\cdots$ & 0.6 & -0.1 \\
\hline & \multicolumn{5}{|c|}{ (In percent of non-oil GDP) } \\
\hline Total retained revenues & 1.5 & 1.6 & 2.4 & 1.8 & 1.5 \\
\hline Aviation & 0.3 & 0.3 & 0.3 & 0.2 & 0.2 \\
\hline Port & 0.3 & 0.3 & 0.3 & 0.3 & 0.3 \\
\hline Power & 0.8 & 1.0 & 1.8 & 1.4 & 0.9 \\
\hline Total expenditures & 3.7 & 3.2 & 3.8 & 3.3 & 5.9 \\
\hline Aviation & 0.2 & 0.2 & 0.3 & 0.1 & 0.4 \\
\hline Port & 0.2 & 0.1 & 0.3 & 0.1 & 1.0 \\
\hline Power & 3.3 & 2.9 & 3.3 & 3.1 & 4.4 \\
\hline
\end{tabular}

Sources: Data provided by the Timor-Leste authorities, and Fund staff estimates and calculations.

1/ Fiscal year: July-June. Actuals are presented on a cash accounting basis. The budget is prepared on a commitments basis. 2/ The Institute of Equipment Management and SAMES were created in 2005/06. 
Table 15. Timor-Leste: Operations of the Power Authority, 2001/02 - 2006/07 1/

\begin{tabular}{|c|c|c|c|c|c|}
\hline & $2002 / 03$ & $2003 / 04$ & $2004 / 05$ & $\begin{array}{c}2005 / 06 \\
\text { Est. }\end{array}$ & $\begin{array}{c}2006 / 07 \\
\text { Budget }\end{array}$ \\
\hline & \multicolumn{5}{|c|}{ (In thousands of U.S. dollars) } \\
\hline Revenue collection & 2,871 & 3,526 & 6,197 & 5,579 & 4,000 \\
\hline Expenditure & 11,201 & 9,717 & 11,417 & 10,791 & 18,547 \\
\hline Wages and salaries & 309 & 269 & 280 & 291 & 368 \\
\hline Goods and services & 8,843 & 9,306 & 10,871 & 10,459 & 16,153 \\
\hline Fuel & 7,950 & 7,732 & 8,631 & 9,243 & 14,875 \\
\hline Maintenance & 386 & 756 & 789 & 979 & 813 \\
\hline Other & 508 & 819 & 1,452 & 236 & 465 \\
\hline Capital expenditure & 2,049 & 142 & 266 & 42 & 2,026 \\
\hline Of which : Prepayment meter project 2/ & 1,900 & 0 & n.a. & n.a. & n.a. \\
\hline Operating balance & $-6,281$ & $-6,049$ & $-4,954$ & $-5,170$ & $-12,521$ \\
\hline Overall balance & $-8,330$ & $-6,191$ & $-5,220$ & $-5,212$ & $-14,547$ \\
\hline Financing & 8,330 & 6,191 & 5,220 & 5,212 & 14,547 \\
\hline Budget transfers & 8,442 & 6,557 & 5,510 & 5,521 & 12,411 \\
\hline External assistance & 0 & 0 & 0 & 0 & 0 \\
\hline \multirow[t]{2}{*}{ Other } & -112 & -366 & -290 & -309 & 2,136 \\
\hline & \multicolumn{5}{|c|}{ (In percent of GDP) } \\
\hline Revenue collection & 0.8 & 1.0 & 1.8 & 1.6 & 0.9 \\
\hline Expenditure & 3.3 & 2.9 & 3.3 & 3.1 & 4.4 \\
\hline Wages and salaries & 0.1 & 0.1 & 0.1 & 0.1 & 0.1 \\
\hline Goods and services & 2.6 & 2.8 & 3.2 & 3.0 & 3.8 \\
\hline Capital expenditure & 0.6 & 0.0 & 0.1 & 0.0 & 0.5 \\
\hline \multirow[t]{2}{*}{ Budget transfers } & 2.5 & 1.9 & 1.6 & 1.6 & 2.9 \\
\hline & \multicolumn{5}{|c|}{ (In percent of total central government expenditure) } \\
\hline Budget transfers & 12.3 & 9.6 & 7.7 & 5.9 & 4.0 \\
\hline & & (In thous & ands of U.S & dollars) & \\
\hline \multicolumn{6}{|l|}{ Memorandum item: } \\
\hline Average monthly revenue collection & 239 & 294 & 516 & 465 & 333 \\
\hline
\end{tabular}

Sources: Data provided by the Timor-Leste authorities, and Fund staff estimates and calculations.

1/ Fiscal year: July-June. Actuals are presented on a cash accounting basis. The budget is prepared on an accruals basis.

2/ The total cost of prepayment meter project was $\$ 2.7$ million, of which $\$ 1.9$ million was provided from the budget, with the remainder financed by Norad and TFET. 
Table 16. Timor-Leste: Combined Sources Fiscal Operations, 2001/02- 2005/06 1/

\begin{tabular}{|c|c|c|c|c|c|}
\hline & $2001 / 02$ & $2002 / 03$ & $2003 / 04$ & $2004 / 05$ & $2005 / 06$ \\
\hline & \multicolumn{5}{|c|}{ Estimates 2/ } \\
\hline & \multicolumn{5}{|c|}{ (In millions of U.S. dollars) } \\
\hline Revenue & 47.7 & 56.8 & 69.7 & 79.2 & 41.2 \\
\hline Domestic revenue $3 /$ & 20.5 & 19.3 & 29.2 & 36.9 & 33.4 \\
\hline Autonomous agencies own revenue & 4.5 & 4.9 & 5.7 & 8.1 & 7.5 \\
\hline Grant financing (budget support) & 22.7 & 32.5 & 34.8 & 34.2 & 0.3 \\
\hline Expenditure (cash basis) & 231.3 & 241.4 & 236.8 & 232.4 & 217.1 \\
\hline Recurrent expenditure & 154.1 & 181.7 & 187.1 & 179.7 & 164.5 \\
\hline Central government budget (incl. autonomous agencies) & 43.5 & 59.7 & 63.2 & 68.1 & 76.9 \\
\hline Donor projects & 110.6 & 122.0 & 123.9 & 111.6 & 87.6 \\
\hline Capital expenditure & 77.2 & 59.7 & 49.8 & 52.7 & 52.7 \\
\hline Central government budget (incl. autonomous agencies) & 7.7 & 11.4 & 9.2 & 10.4 & 12.9 \\
\hline Donor projects & 69.5 & 48.3 & 40.6 & 42.3 & 39.8 \\
\hline Overall balance non-oil balance & -183.6 & -184.7 & -167.2 & -153.3 & -176.0 \\
\hline Financing & 183.6 & 184.7 & 167.2 & 153.3 & 176.0 \\
\hline Oil fund financing of non-oil central government fiscal deficit & 6.5 & 26.4 & 38.0 & 209.4 & 0.0 \\
\hline Project financing by donors & 180.1 & 170.3 & 164.5 & 153.9 & 127.4 \\
\hline \multirow[t]{2}{*}{ Changes in treasury cash-balances (increase -) } & -3.0 & -12.0 & -35.3 & -210.0 & 48.6 \\
\hline & \multicolumn{5}{|c|}{ (In percent of non-oil GDP) } \\
\hline Revenue & 13.4 & 16.7 & 20.7 & 23.0 & 11.7 \\
\hline Domestic revenue & 5.8 & 5.7 & 8.7 & 10.7 & 9.5 \\
\hline Autonomous agencies own revenue & 1.3 & 1.5 & 1.7 & 2.4 & 2.1 \\
\hline Grant financing (budget support) & 6.4 & 9.6 & 10.3 & 9.9 & 0.1 \\
\hline Expenditure & 65.1 & 71.1 & 70.2 & 67.5 & 61.5 \\
\hline Recurrent expenditure & 43.3 & 53.5 & 55.5 & 52.2 & 46.6 \\
\hline Capital expenditure & 21.7 & 17.6 & 14.8 & 15.3 & 14.9 \\
\hline Overall balance non-oil balance & -51.6 & -54.4 & -49.6 & -44.5 & -49.9 \\
\hline Financing & 51.6 & 54.4 & 49.6 & 44.5 & 49.9 \\
\hline Oil fund financing of non-oil central government fiscal deficit & 1.8 & 7.8 & 11.3 & 60.8 & 0.0 \\
\hline Committed project financing by donors & 50.6 & 50.2 & 48.8 & 44.7 & 36.1 \\
\hline Changes in treasury cash-balances (increase -) & -0.8 & -3.5 & -10.5 & -61.0 & 13.8 \\
\hline
\end{tabular}

Source: Data provided by the Timor-Leste authorities; and Fund staff estimates.

1/ Fiscal year: July-June. Includes general government cash expenditure and expenditure programs undertaken by bilateral donors, UNTAET/UNMISET, and international financial institutions outside the central government budget, but excludes externally funded military expenditures (e.g. UN military peacekeeping).

2/ On the basis of data collected in the register for external assistance of the Ministry of Planning and Finance.

3 / Oil and gas revenue is not excluded and transfers from the Petroleum Fund are shown as financing. 
Table 17. Timor-Leste: Balance of Payments, 2001-06

\begin{tabular}{|c|c|c|c|c|c|c|}
\hline & 2001 & 2002 & 2003 & 2004 & 2005 & 2006 \\
\hline & \multicolumn{6}{|c|}{ Estimates } \\
\hline & \multicolumn{6}{|c|}{ (In millions of U.S. dollars) } \\
\hline Current account excl. international assistance & -301 & -244 & -208 & -15 & 193 & 329 \\
\hline Current account incl. international assistance & -194 & -128 & -85 & 103 & 292 & 411 \\
\hline Trade balance & -257 & -211 & -186 & -154 & -127 & -133 \\
\hline Exports of goods $1 /$ & 4 & 6 & 8 & 8 & 9 & 8 \\
\hline O/w: coffee & 4 & 5 & 7 & 7 & 8 & 6 \\
\hline Imports of goods & -262 & -218 & -194 & -163 & -137 & -141 \\
\hline O/w: international assistance-related & -222 & -174 & -155 & -114 & -82 & -71 \\
\hline Services (net) & -48 & -44 & -37 & -32 & -27 & -33 \\
\hline Income (net) & 5 & 4 & 4 & 43 & 83 & 117 \\
\hline O/w: oil/gas royalty and interest & 3 & 2 & 2 & 39 & 79 & 115 \\
\hline Current transfers (net) & 107 & 123 & 134 & 246 & 363 & 460 \\
\hline O/w: oil/gas tax revenue & 0 & 7 & 11 & 129 & 264 & 377 \\
\hline international assistance & 107 & 116 & 123 & 118 & 100 & 82 \\
\hline Capital and financial accounts & 202 & 148 & 103 & 18 & 49 & 71 \\
\hline Official capital transfers & 60 & 59 & 44 & 41 & 41 & 44 \\
\hline Financial account & 142 & 89 & 59 & -23 & 8 & 27 \\
\hline Overall balance (incl. international assistance) & 8 & 20 & 18 & 121 & 341 & 482 \\
\hline Changes in foreign assets (increase -) & -8 & -20 & -18 & -121 & -341 & -482 \\
\hline Oil/gas revenue savings (increase -) & -2 & -13 & -16 & -119 & -330 & -482 \\
\hline \multirow[t]{2}{*}{ Other } & -6 & -7 & -2 & -2 & -11 & 0 \\
\hline & \multicolumn{6}{|c|}{ (In percent of GDP) } \\
\hline Current account excl. international assistance & -82 & -71 & -62 & -4 & 55 & 93 \\
\hline Current account incl. international assistance & -53 & -37 & -25 & 30 & 84 & 116 \\
\hline \multirow[t]{2}{*}{ Trade balance } & -70 & -62 & -55 & -46 & -36 & -38 \\
\hline & \multicolumn{6}{|c|}{ (In millions of U.S. dollars) } \\
\hline \multicolumn{7}{|l|}{ Memorandum items: } \\
\hline Oil/gas revenue & 3 & 9 & 13 & 168 & 342 & 492 \\
\hline Gross foreign assets (end-period) 2/ & 24 & 44 & 61 & 182 & 523 & 1006 \\
\hline
\end{tabular}

Source: Data provided by the Timor-Leste authorities, and Fund staff estimates.

1/ Exclude oil/gas revenues, which are recorded under the income (royalties) and transfers (tax revenues) because of lack of detailed data on the oil/gas sector (including production, exports, service payments, and profit remittances). 2/ Includes foreign assets of the BPA and foreign assets held by the Petroleum Fund from September 2005. 


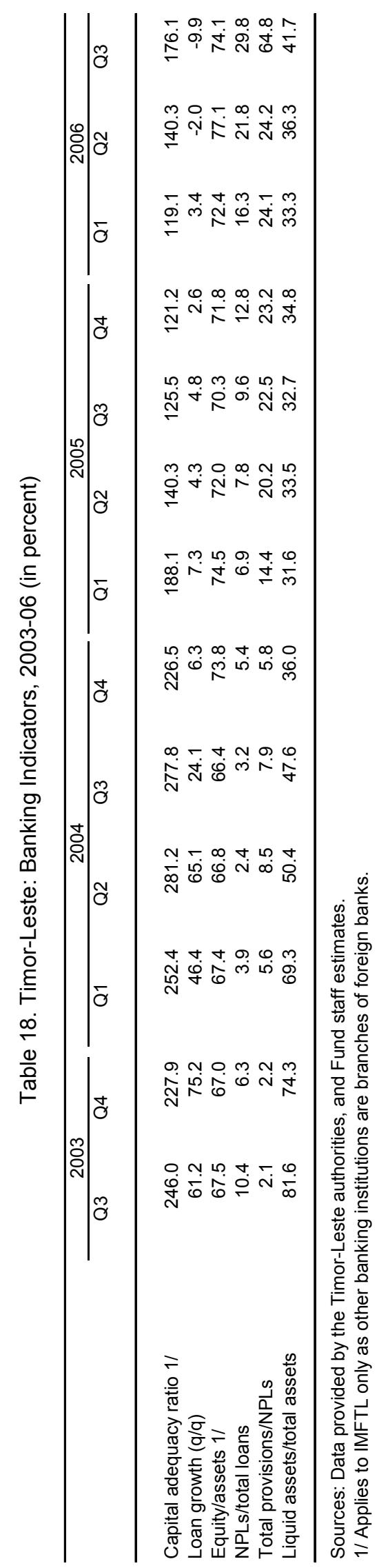




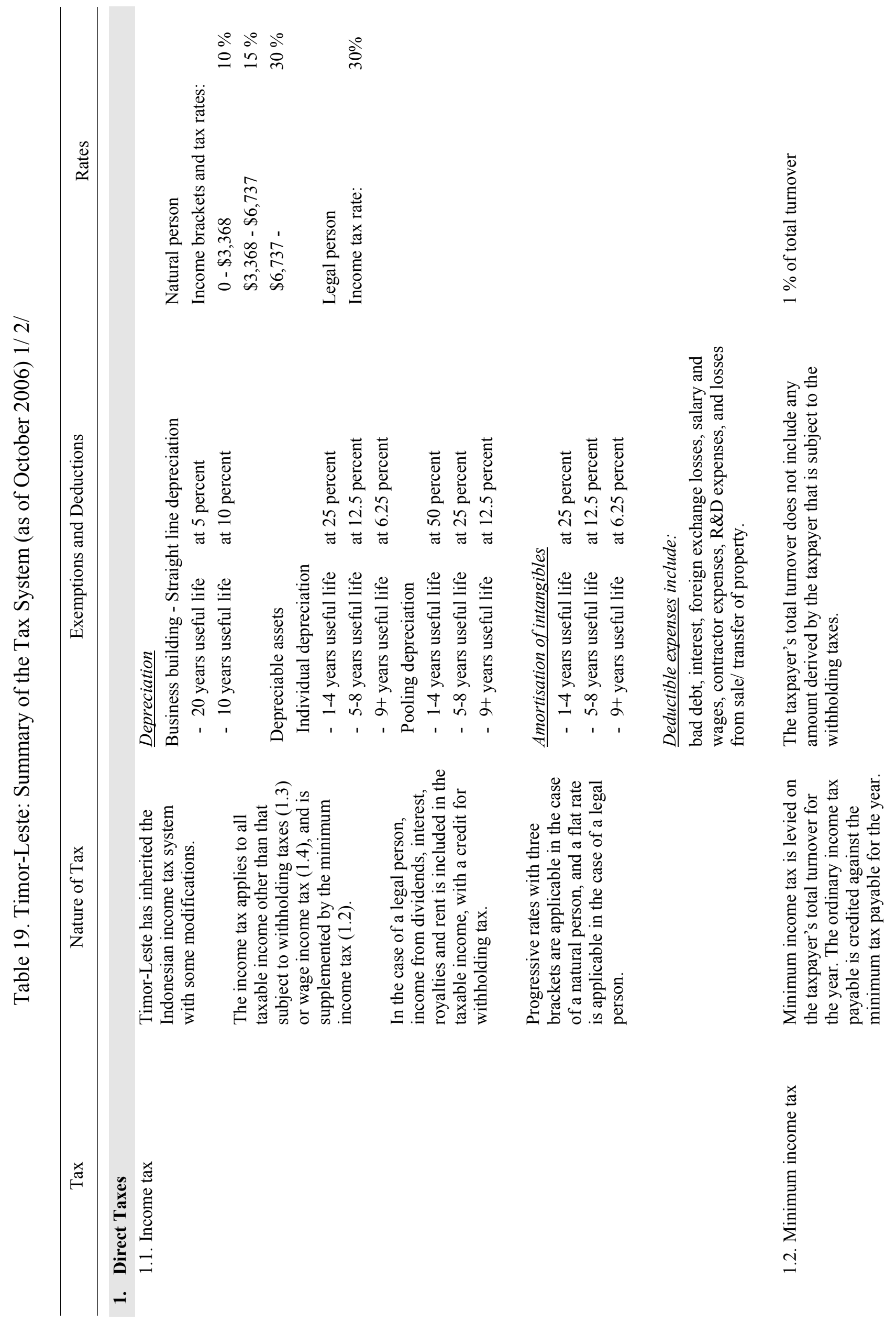




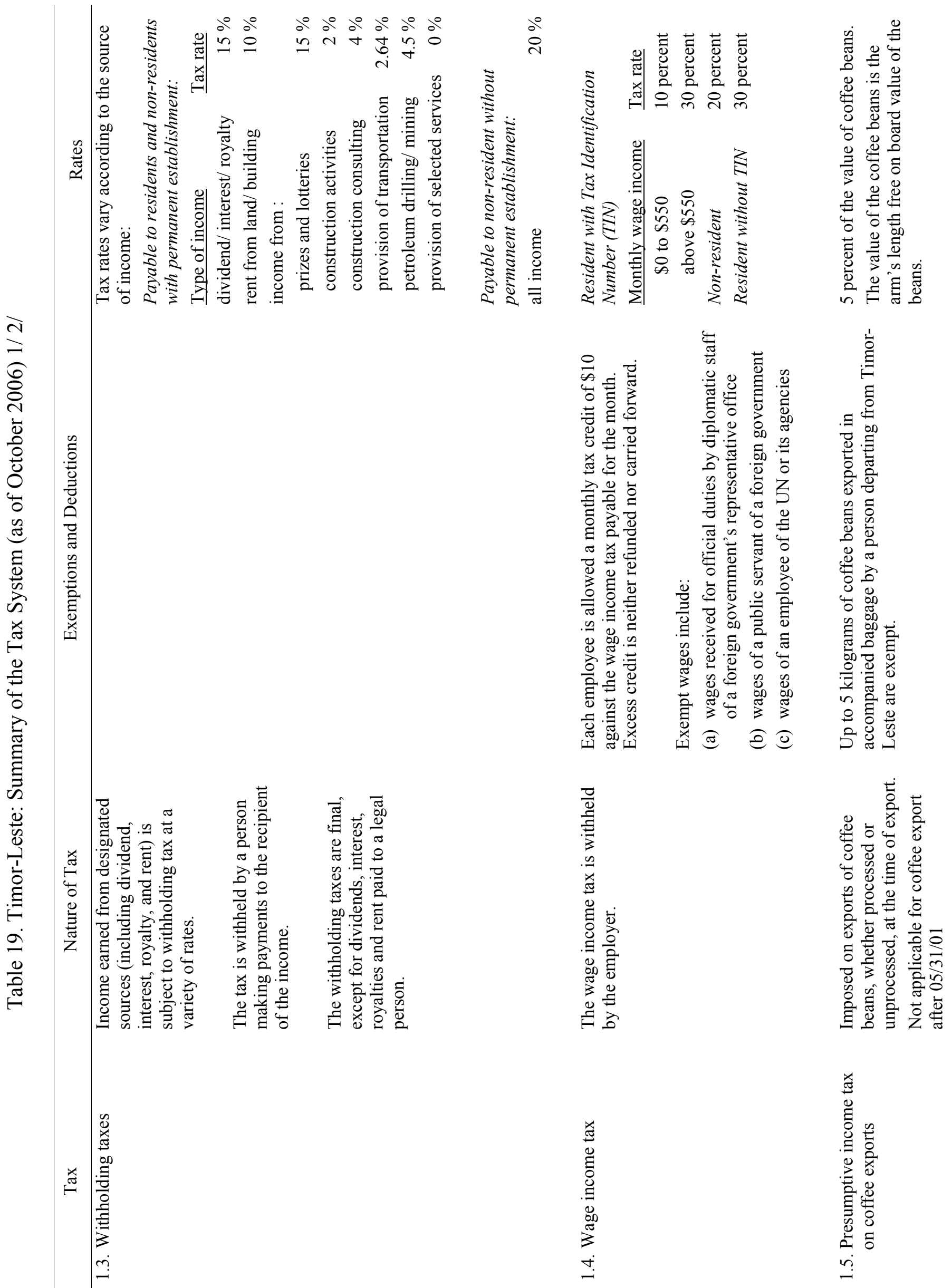




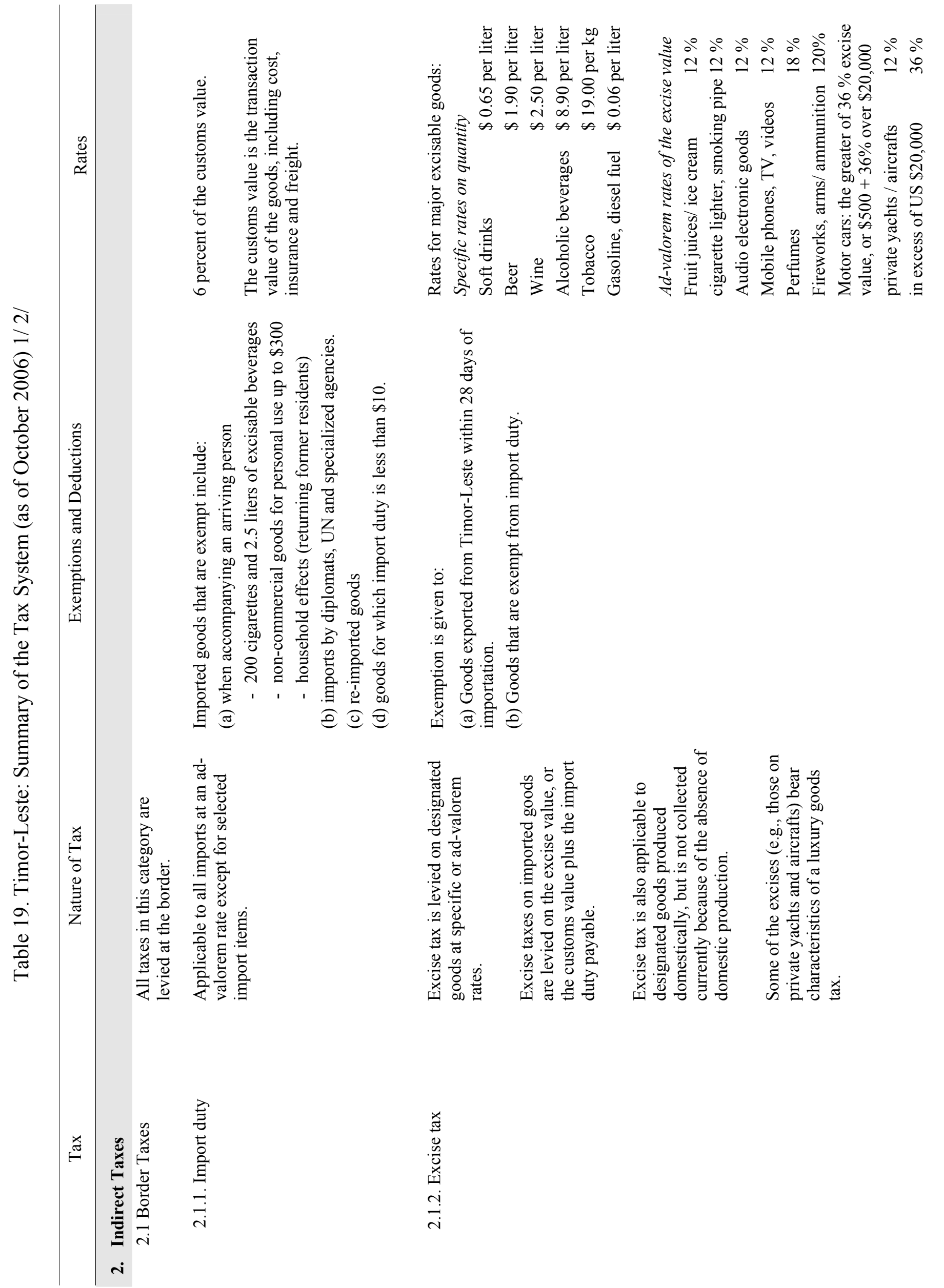




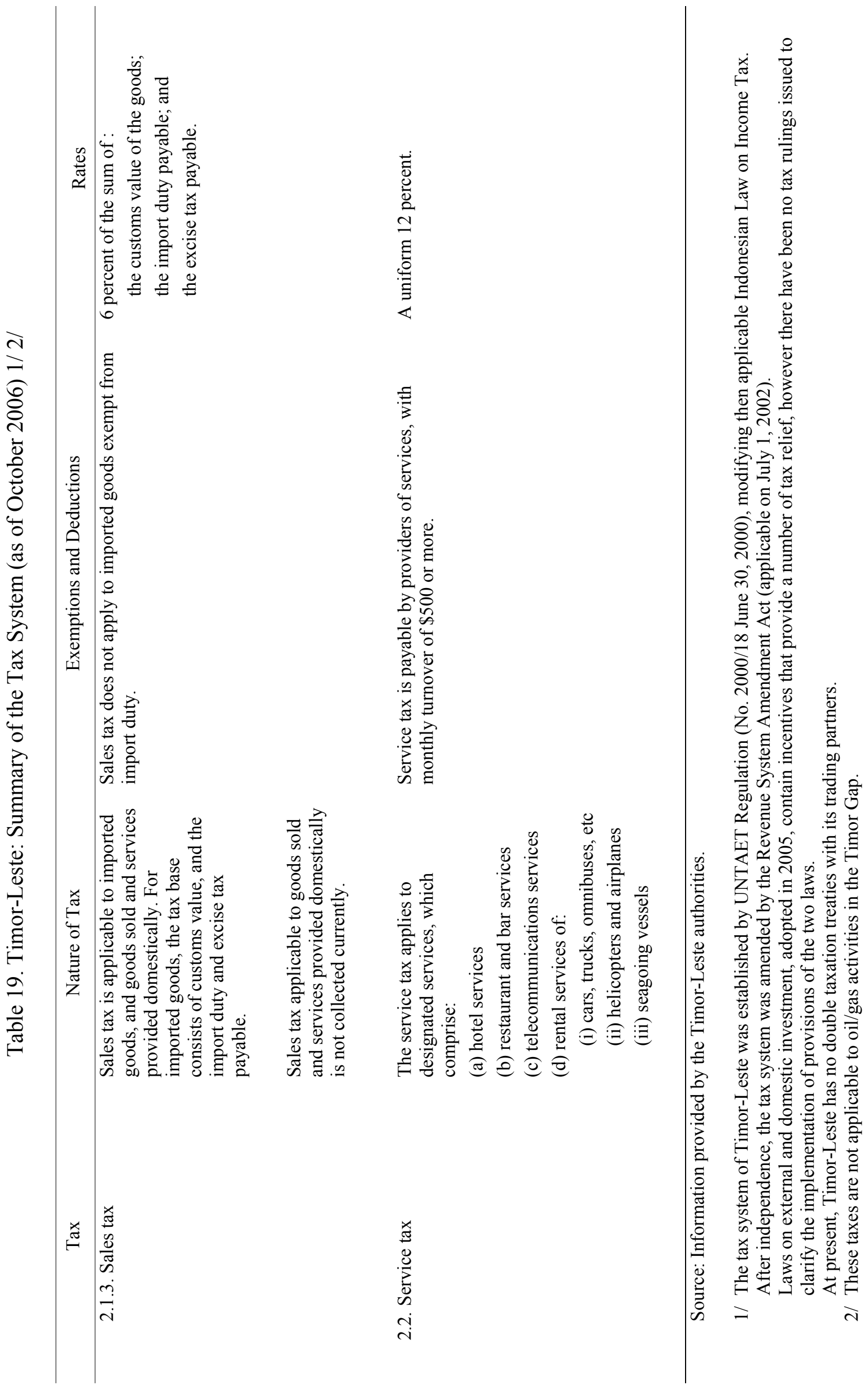

